ORNL/TM-2019/1200

Revision 0

\title{
Safety Testing and Destructive Examination of AGR-2 UCO Compact 6-4-3
}

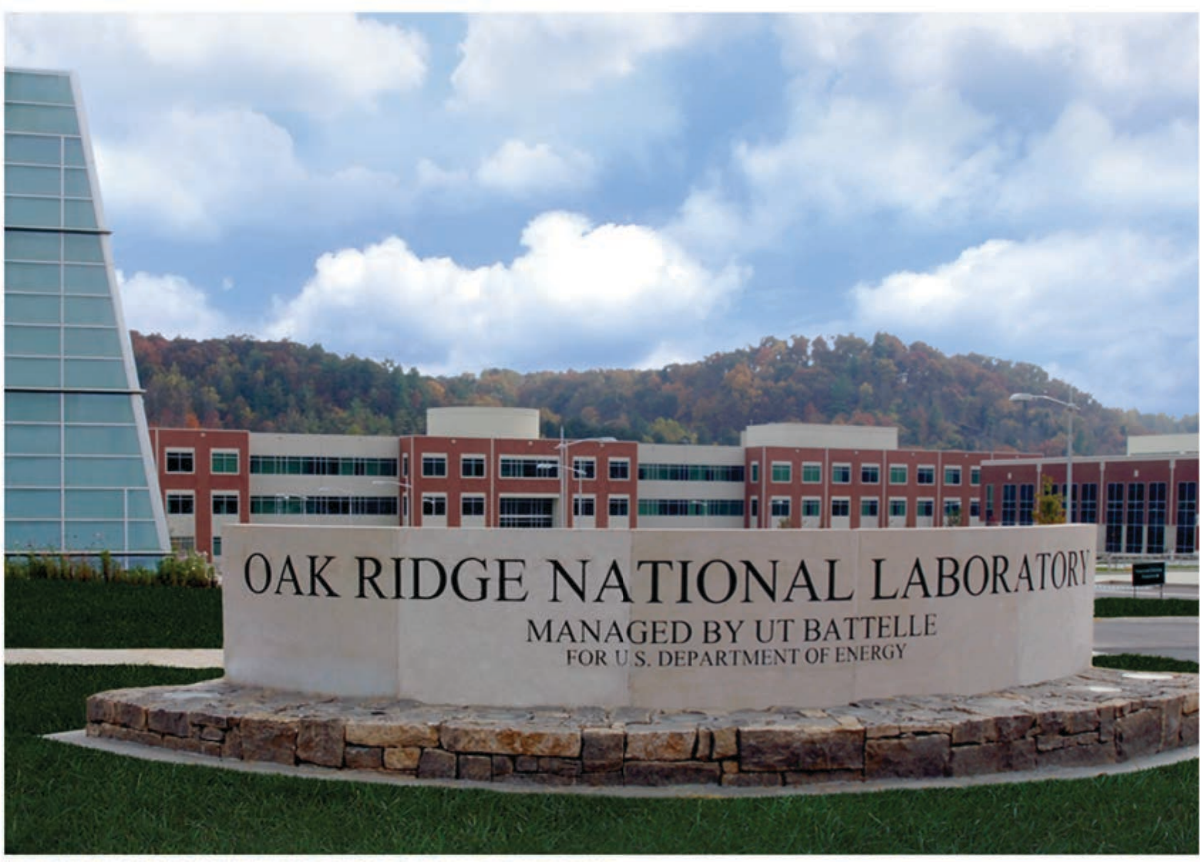

Approved for public release. Distribution is unlimited.

John D. Hunn

Tyler J. Gerczak

Robert N. Morris

Fred C. Montgomery

Darren J. Skitt

Brian D. Eckhart

Zachary M. Burns

June 2019 


\title{
DOCUMENT AVAILABILITY
}

Reports produced after January 1, 1996, are generally available free via US Department of Energy (DOE) SciTech Connect.

Website www.osti.gov

Reports produced before January 1, 1996, may be purchased by members of the public from the following source:

\author{
National Technical Information Service \\ 5285 Port Royal Road \\ Springfield, VA 22161 \\ Telephone 703-605-6000 (1-800-553-6847) \\ TDD 703-487-4639 \\ Fax 703-605-6900 \\ E-mail info@ntis.gov \\ Website http://classic.ntis.gov/
}

Reports are available to DOE employees, DOE contractors, Energy Technology Data Exchange representatives, and International Nuclear Information System representatives from the following source:

Office of Scientific and Technical Information

PO Box 62

Oak Ridge, TN 37831

Telephone 865-576-8401

Fax 865-576-5728

E-mail reports@osti.gov

Website http://www.osti.gov/contact.html

This report was prepared as an account of work sponsored by an agency of the United States Government. Neither the United States Government nor any agency thereof, nor any of their employees, makes any warranty, express or implied, or assumes any legal liability or responsibility for the accuracy, completeness, or usefulness of any information, apparatus, product, or process disclosed, or represents that its use would not infringe privately owned rights. Reference herein to any specific commercial product, process, or service by trade name, trademark, manufacturer, or otherwise, does not necessarily constitute or imply its endorsement, recommendation, or favoring by the United States Government or any agency thereof. The views and opinions of authors expressed herein do not necessarily state or reflect those of the United States Government or any agency thereof. 
Reactor and Nuclear Systems Division

\title{
SAFETY TESTING AND DESTRUCTIVE EXAMINATION OF AGR-2 UCO COMPACT 6-4-3
}

\author{
John D. Hunn \\ Tyler J. Gerczak \\ Robert N. Morris \\ Fred C. Montgomery \\ Darren J. Skitt \\ Brian D. Eckhart \\ Zachary M. Burns
}

Revision 0

Date Published: June 2019

\author{
Work sponsored by \\ US DEPARTMENT OF ENERGY \\ Office of Nuclear Energy - Advanced Reactor Technologies \\ under the \\ Advanced Gas Reactor Fuel Development and Qualification Program \\ Prepared by \\ OAK RIDGE NATIONAL LABORATORY \\ Oak Ridge, TN 37831-6283 \\ managed by \\ UT-BATTELLE, LLC \\ for the \\ US DEPARTMENT OF ENERGY \\ under contract DE-AC05-00OR22725
}





\section{CONTENTS}

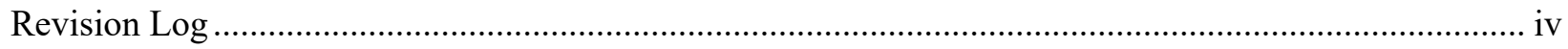

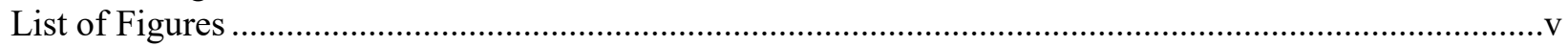

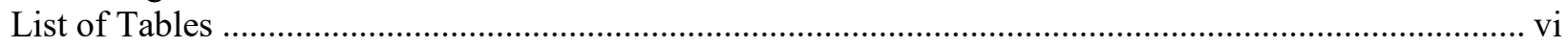

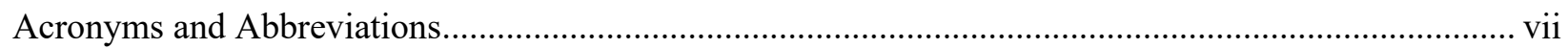

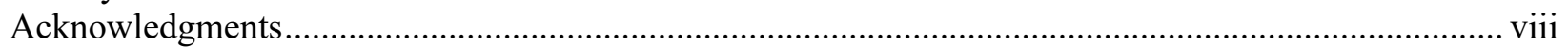

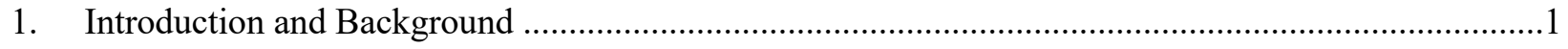

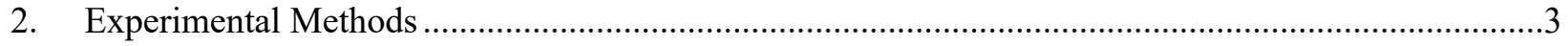

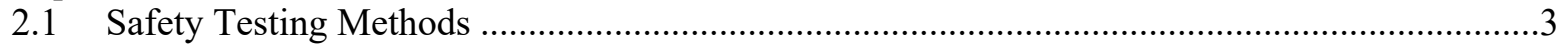

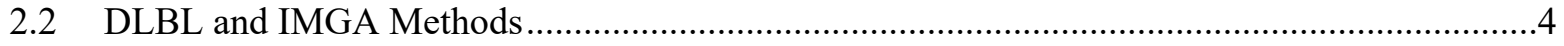

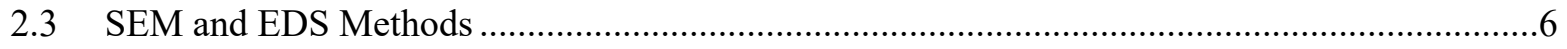

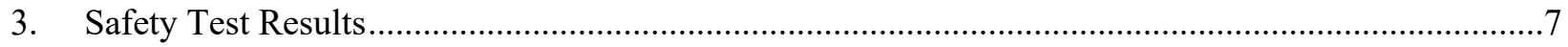

3.1 Cesium and Krypton Release During Safety Testing ….....................................................

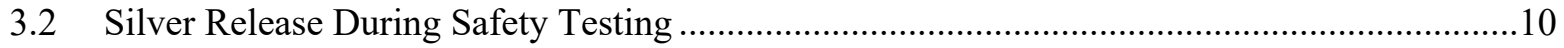

3.3 Strontium, Europium, and Palladium Release During Safety Testing ....................................10

4. Deconsolidation and Leach-Burn-Leach Analysis ....................................................................12

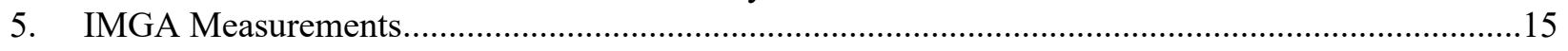

5.1 IMGA Survey of Deconsolidated TRISO Particles ...........................................................15

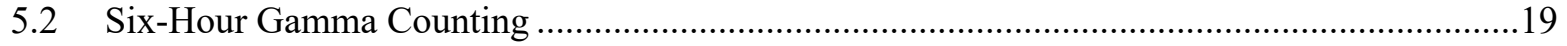

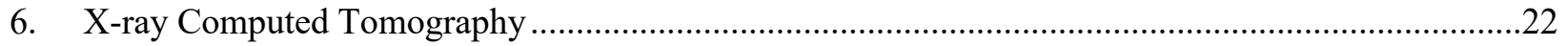

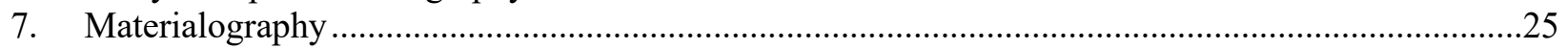

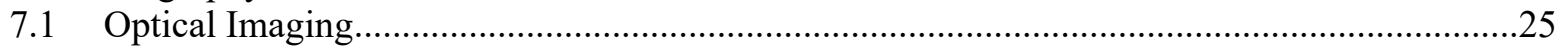

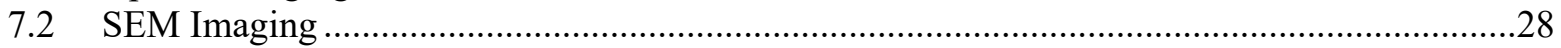

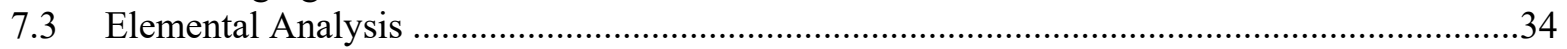

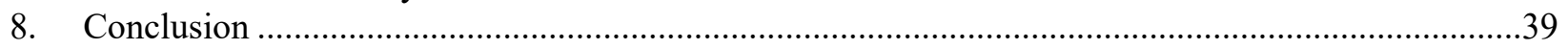

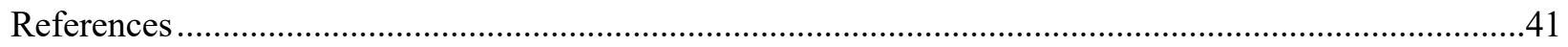




\section{REVISION LOG}

\begin{tabular}{llll}
\hline Revision & Date & Affected Pages & Revision Description \\
\hline 0 & & All & Initial issue
\end{tabular}




\section{LIST OF FIGURES}

2-1. Process flow for DLBL and IMGA.

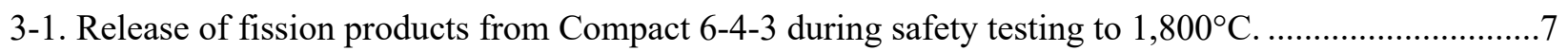

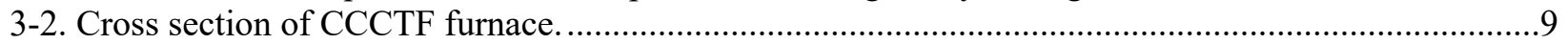

3-3. Rate of fission product release from Compact 6-4-3 during safety testing to $1,800^{\circ} \mathrm{C} \ldots \ldots \ldots \ldots \ldots \ldots \ldots . . . . . . .10$

3-4. Rate of fission product release from Compact 6-4-3 during safety testing to $1,800^{\circ} \mathrm{C} \ldots \ldots \ldots \ldots \ldots \ldots \ldots . . . . . . . .11$

5-1. Particle distribution for measured ${ }^{137} \mathrm{Cs}$ activity, normalized to the average. .....................................15

5-2. Particle distribution for measured ${ }^{144} \mathrm{Ce}$ activity, normalized to the average.......................................16

5-3. Ratio of $137 \mathrm{Cs}$ retained in 2,510 Compact 6-4-3 particles after safety testing to $1,800^{\circ} \mathrm{C}$ vs. the calculated inventory, adjusted for variation in fissionable material and burnup with the measured $144 \mathrm{Ce}$ activity.

5-4. Optical micrograph showing one of the dimpled particles amid numerous undersized particles that were separated from Batch G83J-14-93073A by rollermicrometer sorting prior to compacting.

5-5. Optical micrograph showing one of the dimpled particles found in Batch G83J-14-93072A when undersized particles were separated by rollermicrometer sorting prior to compacting. .......17

5-6. X-ray tomogram of the dimpled particle from Figure 5-5, showing that a fractured kernel was the source of the dimple (bright spots at the buffer/IPyC boundary are clusters of dispersed uranium).

5-7. X-ray tomogram of Particle 643-SP01 showing that the outer three TRISO layers were missing. .....18

5-8. Micrographs of (a) Particle 643-SP02 with all TRISO layers missing, (b) Particle 643-SP03 with a piece of buffer and three outer TRISO layers missing, (c) Particle 643-SP04 with three outer TRISO layers missing, and (d) a typical Compact 6-4-3 particle for comparison. ......19

6-1. Orthogonal tomograms through the center of Particle 643-RS33 .................................................23

6-2. Orthogonal tomograms through the center of Particle 643-RS38 ....................................................24

7-1. Optical micrograph of Particle 642-RS12 near midplane..............................................................26

7-2. Optical micrograph of Particle 642-RS15 near midplane...............................................................26

7-3. Optical micrograph of Particle 642-RS27 near midplane...........................................................27

7-4. Optical micrograph of Particle 642-RS43 near midplane.............................................................27

7-5. Four 500 $\times$ SEM magnification BEC images of Particle $643-\mathrm{RS} 12$ with ${ }^{110 \mathrm{~m}} \mathrm{Ag} \mathrm{M} / \mathrm{C}<1.25 \ldots \ldots \ldots \ldots . .29$

7-6. Two $1500 \times$ SEM magnification BEC images of Particle 643-RS12 with ${ }^{110 \mathrm{~m}} \mathrm{Ag} \mathrm{M} / \mathrm{C}<1.25 \ldots \ldots \ldots \ldots .29$

7-7. Four 500 $\times$ SEM magnification BEC images of Particle 643-RS15 with ${ }^{110 \mathrm{~m}} \mathrm{Ag} \mathrm{M} / \mathrm{C}=1.29 \ldots \ldots \ldots \ldots . .30$

7-8. Two $1500 \times$ SEM magnification BEC images of Particle $643-\mathrm{RS} 15$ with ${ }^{110 \mathrm{~m}} \mathrm{Ag} \mathrm{M} / \mathrm{C}=1.29 \ldots \ldots \ldots . .30$

7-9. Four 500 $\times$ SEM magnification BEC images of Particle 643-RS27 with ${ }^{110 \mathrm{~m}} \mathrm{Ag} \mathrm{M} / \mathrm{C}<0.93 \ldots \ldots \ldots \ldots . .31$

7-10. Two $1500 \times$ SEM magnification BEC images of Particle $643-\mathrm{RS} 27$ with ${ }^{110 \mathrm{~m}} \mathrm{Ag} \mathrm{M} / \mathrm{C}<0.93 \ldots \ldots \ldots . .31$

7-11. Four 500 $\times$ SEM magnification BEC images of Particle 643-RS43 with ${ }^{110 \mathrm{~m}} \mathrm{Ag} \mathrm{M} / \mathrm{C}<1.43 \ldots \ldots \ldots . . .32$

7-12. Two $1500 \times$ SEM magnification BEC images of Particle $643-\mathrm{RS} 43$ with ${ }^{110 \mathrm{~m}} \mathrm{Ag} \mathrm{M} / \mathrm{C}<1.43 \ldots \ldots \ldots . .32$

7-13. BEC and SEI micrographs of the same region of Particle 643-RS27. .........................................33

7-14. BEC and SEI micrographs of the same region of Particle 643-RS27. ..........................................33

7-15. Magnified view of upper area of micrographs in Figure 7-14 showing apparent SiC

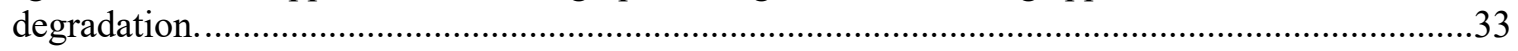

7-16. Examples of U-rich features embedded in the SiC layer of Particle 643-RS12. ...........................35

7-17. EDS spectra of Point-ID locations centered on U-rich features labeled in Figure 7-16...................35

7-18. Examples of complex features embedded in the SiC layer of Particle 643-RS27............................36

7-19. EDS spectra of Point-ID locations centered on complex features labeled in Figure 7-18..................36

7-20. Composition of complex features at different locations in the IPyC of Particle 643-RS27..............37

7-21. EDS spectra of Point-ID locations centered on complex features labeled in Figure 7-20..................37 


\section{LIST OF TABLES}

1-1. Irradiation conditions for AGR-2 UCO Compact 6-4-3 discussed in this report...............................2

3-1. Fission product distribution on furnace internal components after the safety test ............................

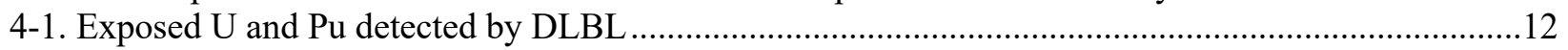

4-2. Exposed compact inventory fractions ${ }^{a}$ of typically tracked beta/gamma-emitting fission

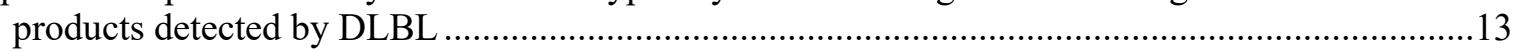

4-3. Exposed compact inventory fractions ${ }^{a}$ of stable isotopes of interest detected by DLBL ...................14

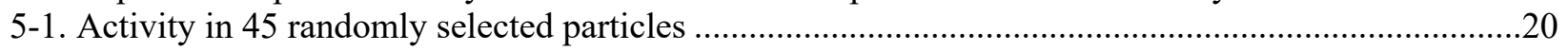

5-2. Summary of results from 6-hour IMGA analysis of Compact 6-4-3 particles ..................................21

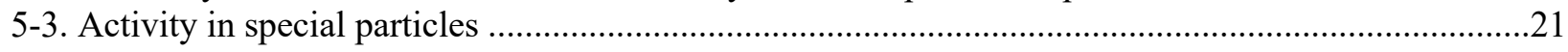

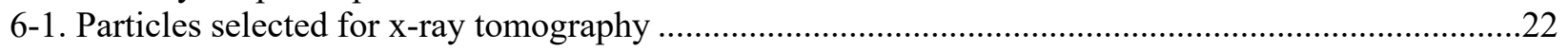

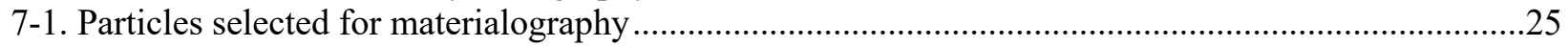

7-2. Relative population of each compositional type observed in high-Z SiC features .............................38

7-3. Relative population of each compositional type observed in high-Z boundary features ......................38

7-4. Relative population of each compositional type observed in high-Z interface features .......................38

7-5. Relative population of each compositional type observed in high-Z IPyC features ...........................38 


\section{ACRONYMS AND ABBREVIATIONS}

AGR

AGR-1

AGR-2

AGR-5/6/7

BEC

BWXT

CCCTF

$\mathrm{CO}$

DLBL

EDS

EOL

FIMA

HTGR

ID

IFEL

IMGA

INL

IPyC

$\mathrm{M} / \mathrm{C}$

$\mathrm{M} / \mathrm{A}$

OPyC

ORNL

PGS

PIE

RS

SEI

SEM

$\mathrm{SiC}$

SP

$\mathrm{TA}_{\min }$

$\mathrm{TA}_{\max }$

TAVA

TRISO

UCO

$\mathrm{UO}_{2}$

$\mathrm{XCT}$

$\mathrm{Z}$
Advanced Gas Reactor (Fuel Development and Qualification Program)

first AGR program irradiation experiment

second AGR program irradiation experiment

fifth, sixth, and seventh AGR program irradiation experiments

backscattered electron/secondary electron composite imaging

BWX Technologies

Core Conduction Cooldown Test Facility

carbon monoxide

deconsolidation and leach-burn-leach

energy-dispersive $\mathrm{x}$-ray spectroscopy

end of life

fissions per initial metal atom

high temperature gas-cooled reactor

identification

Irradiated Fuels Examination Laboratory (hot cells)

Irradiated Microsphere Gamma Analyzer

Idaho National Laboratory

inner pyrolytic carbon (TRISO layer)

measured vs. calculated (inventory fraction)

measured vs. average (inventory fraction)

outer pyrolytic carbon (TRISO layer)

Oak Ridge National Laboratory

Precision Gamma Scanner

post-irradiation examination

randomly selected (particle)

secondary electron imaging

scanning electron microscope or scanning electron microscopy

silicon carbide (TRISO layer)

special particle

time-averaged minimum temperature

time-averaged maximum temperature

time-averaged/volume-averaged temperature

tristructural-isotropic (coated particles)

uranium carbide/uranium oxide mixture (fuel kernels)

uranium dioxide (fuel kernels)

$\mathrm{x}$-ray computed tomography

atomic number 


\section{ACKNOWLEDGMENTS}

This work was sponsored by the US Department of Energy's Office of Nuclear Energy through the Idaho National Laboratory Advanced Reactor Technologies Technology Development Office as part of the Advanced Gas Reactor Fuel Development and Qualification Program. Analysis of leach solutions and Core Conduction Cooldown Test Facility furnace components was conducted by the Oak Ridge National Laboratory Nuclear Analytical Chemistry \& Isotopics Laboratory. Hot cell activities were supported by the staff of the Oak Ridge National Laboratory Irradiated Fuels Examination Laboratory (IFEL). Special thanks to Grant Helmreich for assistance with x-ray tomography. 


\section{INTRODUCTION AND BACKGROUND*}

Post-irradiation examination (PIE) and elevated-temperature safety testing are being performed on tristructural-isotropic (TRISO) coated-particle fuel compacts from the Advanced Gas Reactor (AGR) Fuel Development and Qualification Program's second irradiation experiment (AGR-2). Details on this irradiation experiment have been previously reported (Collin 2014). The AGR-2 PIE effort builds upon the understanding acquired throughout the AGR-1 PIE campaign (Demkowicz et al. 2015) and is establishing a database for the different AGR-2 fuel designs.

The AGR-2 irradiation experiment included TRISO fuel particles coated at BWX Technologies (BWXT) with an engineering-scale coater, which had a coating chamber $150 \mathrm{~mm}$ in diameter. Two coating batches were tested in the AGR-2 irradiation experiment. Batch G73H-10-93085B had uranium dioxide $\left(\mathrm{UO}_{2}\right)$ kernels with an average diameter of $508 \mu \mathrm{m}$. Batch G83J-14-93073A had UCO kernels with an average diameter of $427 \mu \mathrm{m}$; in this kernel design, some of the uranium oxide is converted to uranium carbide during fabrication to provide a getter for oxygen liberated during fission and to limit CO production. Fabrication and property data for the AGR-2 coating batches have been compiled (Barnes and Marshall 2009) and compared to AGR-1 (Phillips, Barnes, and Hunn 2010). The AGR-2 TRISO coatings were most like the AGR-1 Variant 3 TRISO deposited in the Oak Ridge National Laboratory (ORNL) laboratory-scale coater, which had a coating chamber $50 \mathrm{~mm}$ in diameter (Hunn and Lowden 2006). In both cases, the hydrogen and methyltrichlorosilane coating gas mixture that was used to deposit the SiC was diluted with argon to produce a finer grained, more equiaxed $\mathrm{SiC}$ microstructure (Lowden 2006; Gerczak et al. 2016). In addition to the fact that AGR-1 fuel had smaller UCO kernels that were $350 \mu \mathrm{m}$ in diameter, other notable differences in the TRISO particle properties included (1) the pyrocarbon anisotropy, which was slightly higher in the particles coated in the engineering-scale coater, and (2) the exposed kernel defect fraction, which was higher for AGR-2 fuel due to the detected presence of particles with impact damage that was introduced during TRISO particle handling (Hunn 2010).

Irradiation test compacts containing AGR-2 fuel particles were compacted at ORNL using the same blend of natural graphite, synthetic graphite, and phenolic resin that was used to make AGR-1 compacts and a modified pressing process that included a die heated to $65^{\circ} \mathrm{C}$ and a new computer-controlled servo press. Two compact lots were produced and qualified for the AGR-2 irradiation test: lot LEU09-OP2-Z contained the UCO TRISO particles (Hunn, Montgomery, and Pappano 2010a), and lot LEU11-OP2-Z contained the $\mathrm{UO}_{2}$ fuel (Hunn, Montgomery, and Pappano 2010b). Unlike the AGR-1 compacts, which were compacted at room temperature using a manual press, the modified AGR-2 compacting process produced compacts with reduced variability in length and higher matrix density $(1.6-1.7 \mathrm{~g} / \mathrm{cc}$ for AGR-2 versus $1.2-1.3 \mathrm{~g} / \mathrm{cc}$ for AGR-1). Compiled properties data for particles and compacts are available in preirradiation characterization summary reports for AGR-1 (Hunn, Savage, and Silva 2012) and AGR-2 (Hunn, Savage, and Silva 2010) fuel composites.

The AGR-2 Post-Irradiation Examination Plan (Demkowicz 2013) includes activities to (1) complete safety testing of irradiated compacts in the ORNL Core Conduction Cooldown Test Facility (CCCTF) and (2) perform post-safety-test destructive examination on these compacts to evaluate the effect of elevated temperature on fuel microstructure, individual particle coating failure, and overall fission product $^{\dagger}$ and actinide retention. The safety tests typically involve heating compacts in flowing helium to maximum temperatures of $1,600,1,700$, or $1,800^{\circ} \mathrm{C}$ and holding at these temperatures for approximately $300 \mathrm{~h}$. The standard test temperature of $1,600^{\circ} \mathrm{C}$ is the expected maximum temperature during a hightemperature gas-cooled reactor (HTGR) depressurization conduction-cooldown event, while tests with maximum temperatures of $1,700^{\circ} \mathrm{C}$ and $1,800^{\circ} \mathrm{C}$ explore the safety margin and provide additional data on

\footnotetext{
${ }^{*}$ The background text in this section originally appeared in similar form in a previous AGR-2 PIE report (Hunn et al. 2016a) and is included herein for contextual information and definition of common terminology.

$\dagger$ In this report, the term fission product is used to collectively refer to all the various isotopes resulting from irradiation of the fuel compacts, namely, isotopes directly generated by the fission process, isotopes generated by neutron capture, and isotopes generated by radioactive decay.
} 
mechanisms for particle coating failure, fission product and actinide diffusion, and other fission product and actinide interactions with the TRISO coatings.

Destructive PIE includes (1) deconsolidation and leach-burn-leach (DLBL) analysis for exposed fission products and actinides, (2) gamma surveys with short counting times performed using the ORNL Irradiated Gamma Microsphere Analyzer (IMGA) on all the recovered TRISO particles, (3) IMGA measurements with long counting times performed on special particles that have exhibited significant cesium release or other unusual radioisotopic release, and (4) similar IMGA measurements performed on 40-60 randomly selected particles. After completing the IMGA measurements, microstructural analyses using x-ray microtomography and materialographic methods are performed to investigate radiationinduced changes in the particles and to elucidate the mechanisms responsible for observed fission product and actinide release. Materialographic methods typically include mechanical polishing of particle cross section, imaging with an optical microscope, imaging with a scanning electron microscope (SEM), and atomic analysis via energy-dispersive $\mathrm{x}$-ray spectroscopy (EDS).

Previously reported results are available for many AGR-2 compacts. Destructive PIE after safety testing of AGR-2 $\mathrm{UO}_{2}$ Compacts 3-3-2 and 3-4-2 at 1,600 ${ }^{\circ} \mathrm{C}$ (Hunn et al. 2015) and AGR-2 $\mathrm{UO}_{2}$ Compacts 3-4-1 at $1,700^{\circ} \mathrm{C}$ (Hunn et al. 2018a) confirmed cesium release from multiple particles in these $\mathrm{UO}_{2}$ compacts due to $\mathrm{CO}$ corrosion. In contrast, $1,600^{\circ} \mathrm{C}$ safety testing of AGR-2 UCO Compacts 2-2-2, 2-3-1, 5-2-2, and 6-4-2 (Hunn et al. 2016; Hunn et al. 2017) showed no indications of cesium release related to SiC failure, and there was most likely only one failed particle that released cesium in each of the previous three $1,800^{\circ} \mathrm{C}$ safety tests of AGR-2 UCO compacts. The $1,800^{\circ} \mathrm{C}$ safety testing of AGR-2 UCO Compacts 5-4-1 and 2-1-2 induced $\mathrm{SiC}$ failure in one particle in each compact as a result of IPyC fracture that exposed the $\mathrm{SiC}$ to chemical degradation by metal species from the kernel (Hunn et al. 2016; Hunn et al. 2018a; Hunn et al. 2019); this was similar to the type of failure most often observed in AGR-1 safety testing (Hunn et al. 2014a). The $1,800^{\circ} \mathrm{C}$ safety test of AGR-2 UCO Compact 2-3-2 showed cesium and krypton release from a particle with TRISO failure that was caused by molybdenum inclusion in the coating layers during TRISO deposition.

This report presents and discusses results from $1,800^{\circ} \mathrm{C}$ safety testing and post-safety-test destructive examination of AGR-2 UCO Compact 6-4-3. This compact represents the low-temperature, low-burnup end of the spectrum experienced by compacts in the AGR-2 irradiation. Table 1-1 shows the calculated average burnup in percent fissions per initial metal atom (FIMA), the average fast neutron fluence (neutron energies $>0.18 \mathrm{MeV}$ ), and the average compact temperatures during irradiation.

Table 1-1. Irradiation conditions for AGR-2 UCO Compact 6-4-3 discussed in this report

\begin{tabular}{|c|c|c|c|c|c|c|c|}
\hline \multirow{2}{*}{ Compact ID $^{a}$} & \multirow{2}{*}{ Fabrication ID $^{b}$} & \multirow{2}{*}{ Fuel type } & \multirow{2}{*}{$\begin{array}{l}\text { Average burnup }{ }^{c} \\
\text { (FIMA) }\end{array}$} & \multirow{2}{*}{$\begin{array}{l}\text { Fast fluence }^{c} \\
(\mathrm{E}>0.18 \mathrm{MeV})\end{array}$} & \multicolumn{3}{|c|}{ Temperature $^{d}$} \\
\hline & & & & & TAVA & $\mathrm{TA}_{\min }$ & $\mathrm{TA}_{\max }$ \\
\hline AGR-2 6-4-3 & LEU09-OP2- Z028 & $\mathrm{UCO}$ & $7.26 \%$ & $1.94 \times 10^{25} \mathrm{n} / \mathrm{m}^{2}$ & $987^{\circ} \mathrm{C}$ & $868^{\circ} \mathrm{C}$ & $1,080^{\circ} \mathrm{C}$ \\
\hline
\end{tabular}

\footnotetext{
${ }^{a}$ The X-Y-Z compact identification (ID) numbering convention denotes the compact's location in the irradiation test train: capsulelevel-stack.

${ }^{b}$ Physical properties data for individual compacts are available and referenced by fabrication ID (Hunn, Montgomery, and Pappano 2010a, 60-69).

${ }^{c}$ Burnup (Sterbentz 2014, Table 6) and fast fluence (Sterbentz 2014, Table 12) are based on physics calculations.

${ }^{d}$ Time-averaged, volume-averaged (TAVA) temperature, time-averaged minimum $\left(\mathrm{TA}_{\mathrm{min}}\right)$ temperature, and time-averaged maximum $\left(\mathrm{TA}_{\max }\right)$ temperature are based on thermal calculations (Hawkes 2014, Table 3).
} 


\section{EXPERIMENTAL METHODS}

\subsection{SAFETY TESTING METHODS*}

Safety testing in the CCCTF furnace was accomplished using the same methods that were used for AGR-1 safety testing (Baldwin et al. 2012). Compacts were placed in a graphite holder that positions the compact in the furnace and simulates the graphite that surrounds the compacts in a prismatic block reactor. A water-cooled deposition cup located near the top of the tantalum-lined furnace chamber collected vaporized metallic elements that escaped from the compact and the surrounding graphite holder. Deposition cups were periodically removed and replaced with new cups using a maximum exchange interval of $\sim 24 \mathrm{~h}$, and shorter exchange intervals were used for the first few cups removed after heating up to the test temperature. The cups were monitored with gamma spectrometry to track safety test progress, with particular emphasis on the collected cesium inventory that would indicate SiC failure (Hunn et al. 2014a). Gaseous fission products were collected from the helium sweep gas as it passed through a trap cooled with liquid nitrogen. The trap was monitored for ${ }^{85} \mathrm{Kr}$, because significant krypton release would indicate complete failure of a TRISO coating (Morris et al. 2014). After each safety test was completed, additional analysis was performed to measure fission products on the deposition cups and other CCCTF furnace internals (graphite fuel holder, tantalum furnace liner, and tantalum gas inlet line). These data were used to determine the cumulative release of each detected fission product from the compact.

Fission product and actinide measurements were converted to fractions of the total compact inventory using the standard ORNL AGR PIE approach (Hunn et al. 2013, page 6). This method uses the total compact inventory of each isotope that was estimated by performing physics calculations (Sterbentz 2004) to determine the inventory at three specific times after the end of the irradiation, also called the end of life (EOL): one day after, one year after, and two years after. Radioisotope quantities measured by gamma spectrometry (e.g., ${ }^{85} \mathrm{Kr},{ }^{110 \mathrm{~m}} \mathrm{Ag},{ }^{134} \mathrm{Cs},{ }^{137} \mathrm{Cs},{ }^{154} \mathrm{Eu}$, and ${ }^{155} \mathrm{Eu}$ ) or chemical separation and beta spectrometry in the special case of ${ }^{90} \mathrm{Sr}$, were decay-corrected to one day after EOL and divided by the calculated total inventory at that time to determine the total inventory fraction. For stable isotopes such as ${ }^{104} \mathrm{Pd}$ and for actinides (e.g. $,{ }^{235} \mathrm{U},{ }^{236} \mathrm{U},{ }^{238} \mathrm{U},{ }^{239} \mathrm{Pu}$, and ${ }^{240} \mathrm{Pu}$ ), the measured quantity was divided by the calculated total inventory at one year after EOL. This was done because many stable isotope inventories increased significantly over the first year after the compacts were removed from the reactor, while any further increase in the calculated inventories after one year was typically negligible, and the mass spectrometry analysis was almost always performed after one year based on the time required for the test train to cool down and be disassembled. Sometimes results were calculated in terms of the equivalent particle inventory or number of particle-equivalents, which is simply the total compact inventory fraction multiplied by the average number of particles per compact: 3,176 for AGR-2 UCO compacts (Hunn 2010).

The efficiency of collection from the deposition cup varied for different elements due to the variability in transport of elements out of the graphite holder and onto the water-cooled cups. The cumulative fraction of each fission product measured on the deposition cups - relative to the total measured on the cups, tantalum internals, and graphite holder at the end of each safety test-provided a measure of the average deposition cup collection efficiency, which is expected to have varied with time. However, this time dependence could not be determined by a single measurement at the end of the test. To estimate the timedependent release of fission products from the compact, the collection efficiency was assumed to be constant and was used to scale the individual cup measurements. This standard method usually provides a fairly good estimate for some of the more volatile elements such as cesium and silver, but it is often inaccurate for other elements like europium and strontium, which are known to transport relatively slowly onto the deposition cups. Elements that transport slowly onto the deposition cups with respect to the deposition cup exchange interval may appear to have a greater time-dependent increase in the release rate,

\footnotetext{
${ }^{*}$ The text in Section 2.1 describing safety testing methods was duplicated with some revision from a previous report (Hunn et al. 2018a) to provide the necessary background for discussion of the results reported herein.
} 
especially in the early stages of the safety test, due to the assumption of constant cup collection efficiency.

\subsection{DLBL AND IMGA METHODS}

Post-safety test destructive examination was performed using the same methods that were developed for destructive PIE of as-irradiated AGR-1 compacts, and the details of the equipment and methods have been previously reported (Hunn et al. 2013). Figure 2-1 shows the typical process flow for DLBL and IMGA survey. Deconsolidation and hot leach solutions were analyzed by gamma and mass spectrometry, providing information about fission products and actinides that were not sealed inside retentive SiC layers. Fission products and actinides leached in the deconsolidation acid, pre-burn Soxhlet extraction of the particles and matrix, and post-burn pot leach of the matrix came from either (1) uranium contamination outside the $\mathrm{SiC}$ in the as-fabricated compacts, (2) diffusion through the $\mathrm{SiC}$ during irradiation or safety testing, or (3) exposed kernels in particles with failed TRISO. Fission products and actinides leached in the post-burn Soxhlet extraction of the particles came from either (1) exposed kernels in particles with failed $\mathrm{SiC}$, or (2) diffusively released fission products and actinides that were not leached prior to the burn because they were previously sequestered in the outer pyrolytic carbon (OPyC) layer or in an insoluble chemical form.

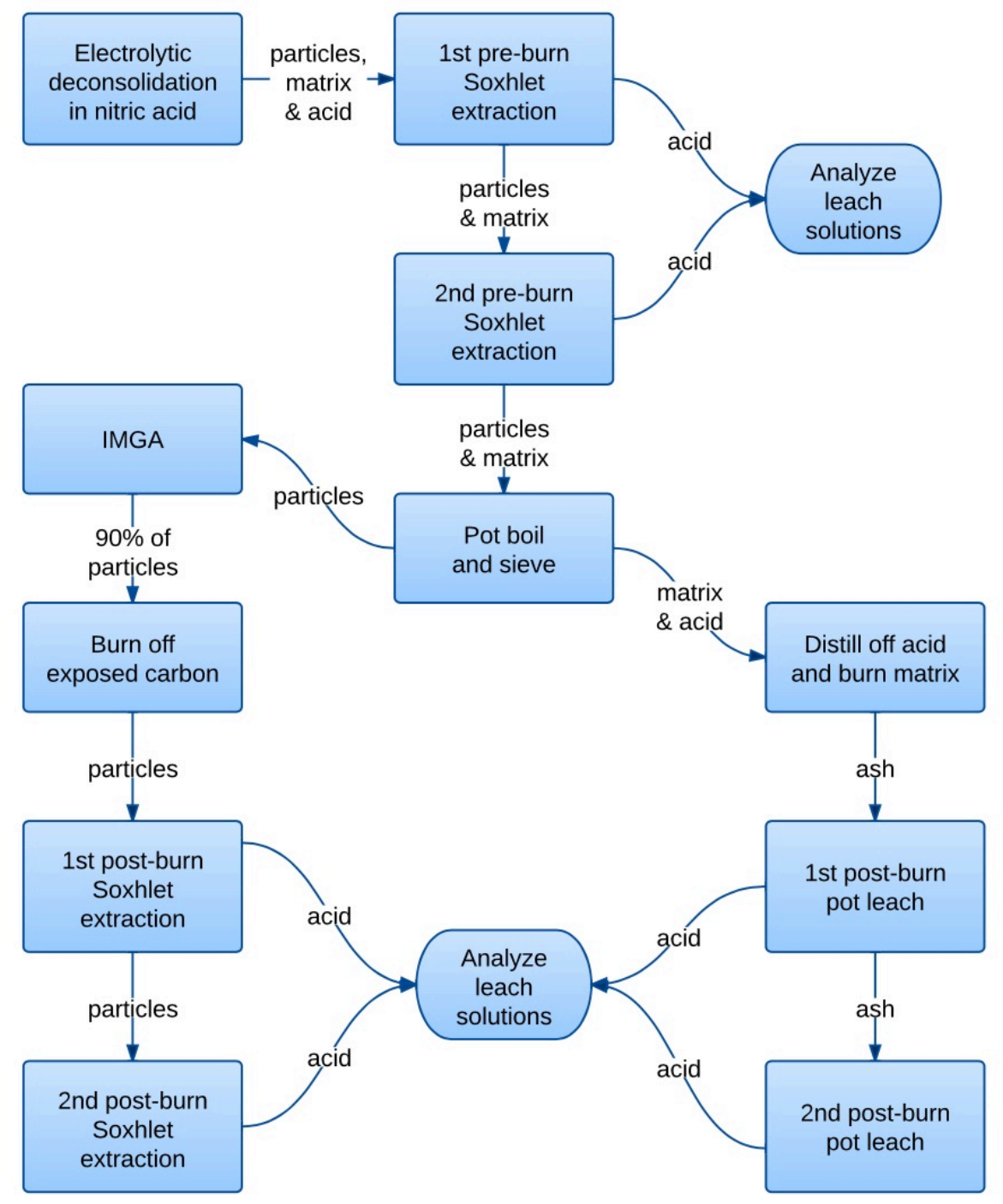

Figure 2-1. Process flow for DLBL and IMGA. 
The DLBL data were decay-corrected and converted to compact inventory fraction and particleequivalent values using the same protocol applied to the safety test data. The IMGA data are reported herein as activities in $\mathrm{Bq} /$ particle that were decay-corrected to one day after EOL or various unitless ratios that communicate the retained fraction of each isotope. The simplest ratio was the measured activity of a particle, $A_{i}$, normalized to the average measured activity for all particles in a sample of $n$ particles. For example,

$$
\frac{\mathrm{A}_{\mathrm{i}}\left({ }^{144} \mathrm{Ce}\right)}{\sum_{\mathrm{i}=1}^{\mathrm{n}}\left(\frac{1}{\mathrm{n}}\right) \mathrm{A}_{\mathrm{i}}\left({ }^{144} \mathrm{Ce}\right)}
$$

is the measured ${ }^{144} \mathrm{Ce}$ activity of Particle $i$, normalized to the average ${ }^{144} \mathrm{Ce}$ activity. Equation 2.1 was used to generate ${ }^{137} \mathrm{Cs}$ and ${ }^{144} \mathrm{Ce}$ histograms of the IMGA survey results, which were centered on unity and had a distribution that resulted from measurement uncertainty and real particle-to-particle variation in isotopic content. For particles with negligible radioisotope release, this real particle-to-particle variation was related to variation in fissionable material and burnup, which might occur due to variation in kernel size and local neutron fluence.

A calculated value for the expected activity of a given isotope in each particle was estimated from the calculated compact activity for that isotope multiplied by the normalized activity of a different and preferably well-retained isotope to adjust for particle-to-particle variation in fissionable material and burnup. For instance,

$$
\mathrm{A}_{\text {calc }}\left({ }^{137} \mathrm{Cs}\right) \frac{\mathrm{A}_{\mathrm{i}}\left({ }^{144} \mathrm{Ce}\right)}{\sum_{\mathrm{i}=1}^{\mathrm{n}}\left(\frac{1}{\mathrm{n}}\right) \mathrm{A}_{\mathrm{i}}\left({ }^{144} \mathrm{Ce}\right)}
$$

is the calculated ${ }^{137} \mathrm{Cs}$ activity of Particle $i$ adjusted for particle-to-particle variation in fissionable material and burnup using the normalized ${ }^{144} \mathrm{Ce}$ activity. The ratio of the measured activity in a particle vs. the calculated expected activity is reported herein as the measured vs. calculated $(\mathrm{M} / \mathrm{C})$ value. For example,

$$
\frac{\mathrm{A}_{\mathrm{i}}\left({ }^{137} \mathrm{Cs}\right)}{\mathrm{A}_{\text {calc }}\left({ }^{137} \mathrm{Cs}\right) \frac{\mathrm{A}_{\mathrm{i}}\left({ }^{144} \mathrm{Ce}\right)}{\sum_{\mathrm{i}=1}^{\mathrm{n}}\left(\frac{1}{\mathrm{n}}\right) \mathrm{A}_{\mathrm{i}}\left({ }^{144} \mathrm{Ce}\right)}}
$$

is the ${ }^{137} \mathrm{Cs} \mathrm{M} / \mathrm{C}$ value for Particle $i$. Equation 2.3 was used to generate a ${ }^{137} \mathrm{Cs} \mathrm{M} / \mathrm{C}$ histogram that illustrated the cesium retention in each particle, where particles with low cesium retention could be identified as discrete values below the main distribution. The $\mathrm{M} / \mathrm{C}$ values were also calculated for other isotopes as useful indicators of particle retention. The average $\mathrm{M} / \mathrm{C}$ for well-retained isotopes was not always close to unity, because error in the calculated inventory sometimes resulted in an offset which could be significant. The offset was substantial for the isotopes of europium and antimony as a result of large errors in the calculated values.

Another calculated ratio, reported herein as the measured vs. average (M/A) value, was determined in a manner similar to that used to determine $\mathrm{M} / \mathrm{C}$, except the offset in the calculated activity was mostly removed by replacing the calculated activity in Equation 2.3 with the average measured activity. For instance,

$$
\frac{\mathrm{A}_{\mathrm{i}}\left({ }^{137} \mathrm{Cs}\right)}{\sum_{\mathrm{i}=1}^{\mathrm{n}}\left(\frac{1}{\mathrm{n}}\right) \mathrm{A}_{\mathrm{i}}\left({ }^{137} \mathrm{Cs}\right) \frac{\mathrm{A}_{\mathrm{i}}\left({ }^{144} \mathrm{Ce}\right)}{\sum_{\mathrm{i}=1}^{\mathrm{n}}\left(\frac{1}{\mathrm{n}}\right) \mathrm{A}_{\mathrm{i}}\left({ }^{144} \mathrm{Ce}\right)}}
$$

is the ${ }^{137} \mathrm{Cs} \mathrm{M} / \mathrm{A}$ value for Particle $i$. This is useful for identifying particles with average retention. 


\subsection{SEM AND EDS METHODS*}

Analysis was performed with a JEOL JSM-6390L SEM equipped with an Oxford X-Max 50 silicon drift detector and the Oxford AZtec analysis software suite for EDS. The SEM was located in a contamination control area in Room 120 of the ORNL IFEL hot cells. The SEM analysis was performed on the mounts previously imaged by optical microscopy. To facilitate analysis, the mounts were transferred out of the hot cell to the IFEL charging area, where initial decontamination was performed to reduce radiological contamination. The mounts were then transferred to a radiological hood located in Room 120 for final radiological decontamination and surface cleaning. The mounts underwent ultrasonic cleaning in deionized water, were rinsed with isopropyl alcohol, and were wiped with a cotton swab. These cleaning and decontamination processes were repeated three times. Following decontamination, the samples were smeared and surveyed prior to being released from the hood. After the samples were released, their surfaces were checked with an optical microscope located in the contamination control area. If the sample surfaces were free of significant debris, then they were secured onto an aluminum SEM stub using conductive carbon tape and colloidal graphite to facilitate SEM analysis.

Two complementary SEM imaging modes - secondary electron imaging (SEI) and backscattered electron composition (BEC) - were performed, as they provide different information on particle cross sections. The secondary electron signal was surface sensitive, which allowed for identification of surface features and any irregularities. The SEI micrographs were obtained using a 3-kV accelerating voltage with a spot size of 40 (a unitless value) and a working distance of $8 \mathrm{~mm}$. The backscattered electron signal was dependent on the atomic number $(Z)$ of the elements near the surface. Because they appeared as bright spots, the high- $Z$ fission products and actinides embedded in the relatively low- $Z$ TRISO layers could be readily identified. The BEC micrographs were obtained using a $20-\mathrm{kV}$ accelerating voltage with a spot size of 64 and a working distance of $10 \mathrm{~mm}$. Image pairs of the same areas were acquired using both imaging modes to ensure that surface features (such as loose debris) were not misinterpreted as embedded features. A general image set was taken for each particle cross section. The image set consisted of particle overview images, low magnification $(500 \times)$ images of the TRISO layers in four cardinal directions, and higher magnification $(1,500 \times)$ images of the $\mathrm{SiC}$ layer in four cardinal and four inter-cardinal directions around the circumference of the particle. Additional images of selected areas of interest were also acquired when necessary.

Two or more locations were chosen on each particle cross section for EDS analysis to gain an understanding of the distribution of fission products and actinides in the TRISO layers after irradiation and safety testing. Point-ID analysis was used to identify local compositions in high-Z features. The Point-ID analysis was acquired under the same conditions as images acquired in the BEC mode, which resulted in a sufficient count rate. The general acquisition parameters used for Point-ID analysis were to collect spectra within an energy range of $0-20 \mathrm{keV}$ with $10 \mathrm{eV} / \mathrm{channel}, 4,096$ channels, a unitless process time of 2, and a live time of $30 \mathrm{~s}$. Data acquired by Point-ID analysis were processed using standardless analysis, and significant contributions from the surrounding matrix were included in the data due to the submicron size of the analyzed features; therefore, information on feature composition was not quantitative. In addition, minor constituents present in the high- $Z$ fission product and actinide features may not be observed. However, the Point-ID analysis information on feature composition was useful for qualitative classification of the features, which supported identification of general trends and comparison of the features observed in different locations in the TRISO layers.

\footnotetext{
* The text in Section 2.3 describing SEM and EDS methods was duplicated with some revision from a previous report (Hunn et al. 2018b) to provide the necessary background for discussion of the results reported herein.
} 


\section{SAFETY TEST RESULTS}

Figure 3-1 shows the estimated time-dependent release of various fission product isotopes during $1,800^{\circ} \mathrm{C}$ safety testing of Compact 6-4-3. Table 3-1 shows the cumulative release and the relative fractions of these fission products on the furnace internals at the end of the safety test. The relative fraction of each isotope on the deposition cups was used as an estimation of the average collection efficiency to generate the timedependent curves presented in Figure 3-1 and described in Section 2.1.

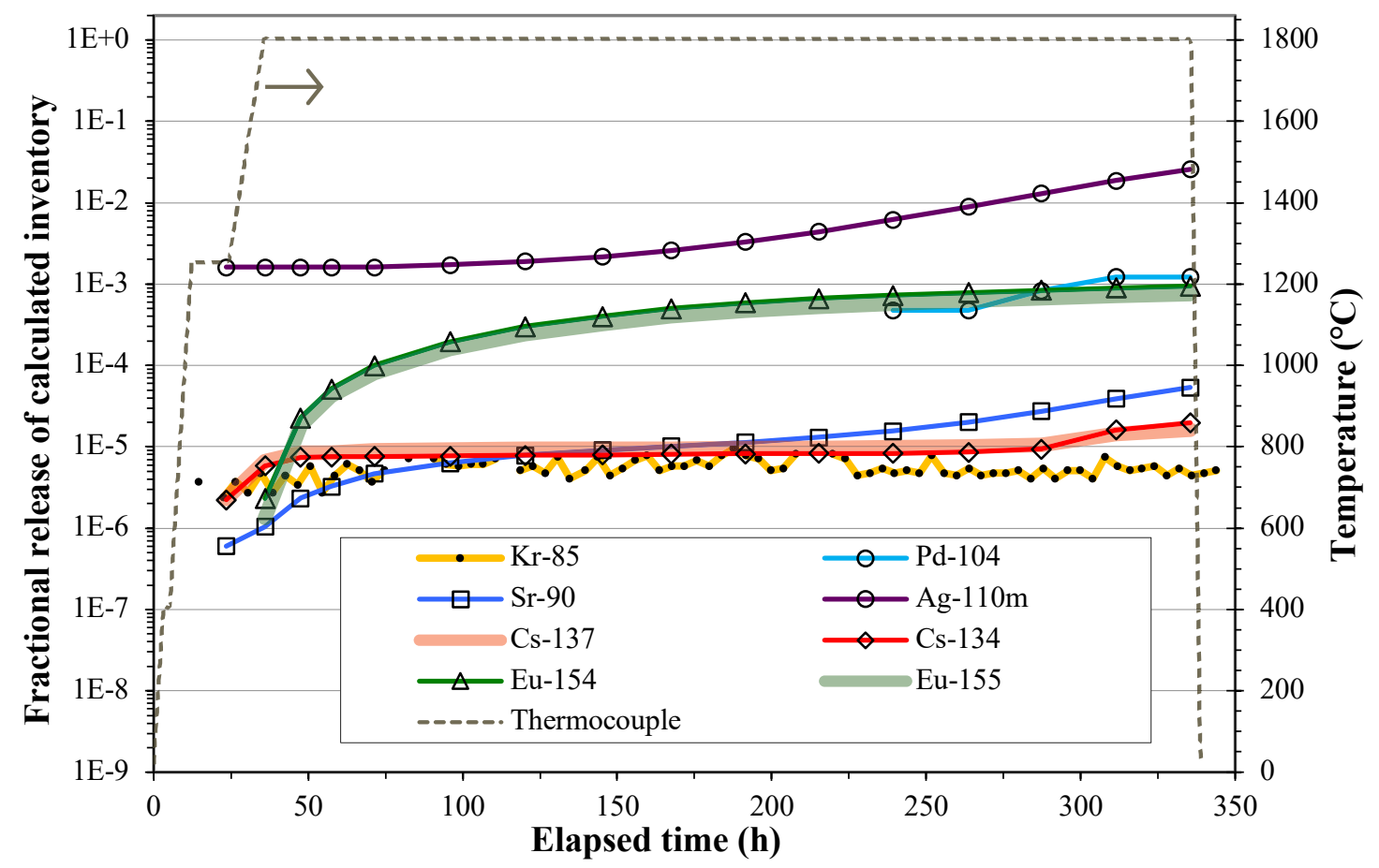

Figure 3-1. Release of fission products from Compact 6-4-3 during safety testing to $1,800^{\circ} \mathrm{C}$.

Table 3-1. Fission product distribution on furnace internal components after the safety test

\begin{tabular}{lccccccc}
\hline Component & ${ }^{\mathbf{9 0}} \mathbf{S r}$ & ${ }^{104} \mathbf{P d}$ & ${ }^{110 m} \mathbf{A g}$ & ${ }^{134} \mathbf{C s}$ & ${ }^{137} \mathbf{C s}$ & ${ }^{154} \mathbf{E u}$ & ${ }^{155} \mathbf{E u}$ \\
\hline Deposition cups ${ }^{a}$ & $65 \%$ & $\sim 100 \%$ & $\sim 100 \%$ & $49 \%$ & $42 \%$ & $74 \%$ & $66 \%$ \\
Tantalum parts & $2.7 \%$ & $\sim 0 \%$ & $\sim 0 \%$ & $34 \%$ & $23 \%$ & $13 \%$ & $16 \%$ \\
Graphite holder & $32 \%$ & $\sim 0 \%$ & $\sim 0 \%$ & $17 \%$ & $35 \%$ & $14 \%$ & $18 \%$ \\
\hdashline Cumulative release $^{b}$ & $5.37 \mathrm{E}-5$ & $1.22 \mathrm{E}-3$ & $2.57 \mathrm{E}-2$ & $1.97 \mathrm{E}-5$ & $1.62 \mathrm{E}-5$ & $9.46 \mathrm{E}-4$ & $7.54 \mathrm{E}-4$ \\
& $(0.17)$ & $(3.9)$ & $(82)$ & $(0.06)$ & $(0.05)$ & $(3.0)$ & $(2.4)$ \\
\hline
\end{tabular}

${ }^{a}$ Cumulative fraction collected on all deposition cups.

${ }^{b}$ Release from compact as fraction of calculated compact inventory and particle-equivalent inventory (in parentheses).

\subsection{CESIUM AND KRYPTON RELEASE DURING SAFETY TESTING}

The total cesium release during safety testing of Compact 6-4-3, 0.05-0.06 particle-equivalents (Table 3-1), was the lowest observed to date during $1,800^{\circ} \mathrm{C}$ testing of AGR-1 and AGR-2 compacts (Morris et al. 2014, Hunn et al. 2018c) and was consistent with a conclusion that no particle experienced retention failure of the $\mathrm{SiC}$ layer. Figure 3-1 shows that 0.02-0.03 particle-equivalents of cesium release was detected at the beginning of the test. Collection of a few percent of the cesium inventory in one particle has often been observed at the beginning of a CCCTF safety test as a result of driving off contamination picked up in the hot cell during handling of the graphite holder and/or from low levels of cesium 
sequestered in the matrix and/or OPyC layer of the irradiated compact. The ratio of ${ }^{134} \mathrm{Cs} /{ }^{137} \mathrm{Cs}$ accumulated on the first four deposition cups was 0.62 , which is consistent with the ratio of 0.61 determined by the physics calculations (Sterbentz 2014). This strongly suggests that the cesium collected at the start of the test was not from hot cell contamination but rather from cesium sequestered in the matrix and/or OPyC of the irradiated compact, which may have come from uranium contamination in the matrix and/or OPyC of the as-fabricated compact and/or from other compacts that released cesium in the irradiation test capsule. These possibilities are supported by the facts that the fraction of uranium measured outside the SiC in 65 as-fabricated compacts was 3.94E-6 (Hunn, Savage, and Silva 2010), and analysis of the Capsule 6 graphite holder measured ${ }^{134} \mathrm{Cs}$ in the holder at a capsule fraction of 3.84E-5 (Stempien and Demkowicz 2019).

After the initial release of cesium, negligible additional cesium was collected until the last $50 \mathrm{~h}$ of the safety test, when an additional few percent of one particle-equivalent was measured on the last three cups. However, the ${ }^{134} \mathrm{Cs} /{ }^{137} \mathrm{Cs}$ ratio accumulated on the last three deposition cups was 1.24 , which was twice the expected ratio, suggesting that the source was not from Compact 6-4-3. It is hypothesized that the cesium release observed during the last $50 \mathrm{~h}$ of the safety test came from residual cesium contamination in the CCCTF air lock through which deposition cups are exchanged during furnace operation. The fact that this contamination was not observed earlier would indicate that something changed that impacted the transfer of contamination to the last three cups. The AGR-2 $\mathrm{UO}_{2}$ compacts tested in the CCCTF had ${ }^{134} \mathrm{Cs} /{ }^{137} \mathrm{Cs}$ ratios of $1.20-1.27$, and some of these compacts released very high amounts of cesium into the furnace; these $\mathrm{UO}_{2}$ compacts may be the primary source of the contamination. Review of the CCCTF test history revealed an additional case that indicated cross contamination between tests. Safety-tested AGR-2 $\mathrm{UO}_{2}$ Compact 3-4-1 had a ${ }^{134} \mathrm{Cs} /{ }^{137} \mathrm{Cs}$ ratio of 1.26 and released $8.7 \%$ of its ${ }^{134} \mathrm{Cs}$ from multiple particles with $\mathrm{CO}$-induced $\mathrm{SiC}$ failure during safety testing (Hunn et al. 2018a). This was the highest cesium release during a CCCTF safety test of AGR fuel compacts observed to date. The next compact tested in the CCCTF was AGR-2 UCO Compact 6-4-2, which had no SiC failure but the cumulative ${ }^{134}$ Cs release of 0.20 particle-equivalents was unusually high for a compact with no particle failure (Hunn et al. 2017). The average ${ }^{134} \mathrm{Cs} /{ }^{137} \mathrm{Cs}$ ratio for cesium released during the Compact 6-4-2 safety test was 1.23 , while the expected ratio was 0.71 . This strongly suggests that the total amount of cesium detected during the safety testing of Compact 6-4-2 was dominated by contamination from the prior test.

Figure 3-2 shows a cross section of the CCCTF furnace with the primary components labeled. Many of the internal components are replaced after each safety test: (1) the graphite holder where the compact resides, (2) the tantalum can lining the furnace interior, (3) the tantalum tube through which the He sweep gas enters the furnace, and (4) the O-rings in the spool piece that form a seal around the cold finger shaft. The cold finger and accessible surfaces of the components that the cold finger passes through when the deposition cups are exchanged during the safety test are wiped down after each test to reduce contamination levels on these components. Radiological surveys indicate that minor amounts of removable contamination remain on the deposition cup cold finger and some other internal airlock surfaces after this cleaning. The contamination levels are the highest on the tantalum thermal shields that pivot to a horizontal position to protect the gate valve from heat radiating from the furnace when the deposition cup is extracted during a test. These heat shields are not wiped down as thoroughly as the other components because they could be damaged by excessive handling. Residual contamination on the components that are not replaced between each test could be transferred to the depositions cups as they pass through the airlock assembly. There is also a possibility the contaminated debris may fall into the furnace when the heat shields are moved during each cup exchange. Cross contamination between CCCTF safety tests has not been previously noted for two reasons. Firstly, most of the compacts tested have a similar ${ }^{134} \mathrm{Cs} /{ }^{137} \mathrm{Cs}$ ratio, which makes identification of cross contamination less obvious. Secondly, prior to safety testing of the AGR-2 $\mathrm{UO}_{2}$ compacts, cesium release has not been as high due to much lower $\mathrm{SiC}$ failure rates. Consideration will be given to performing more thorough cleaning to remove contamination accumulated on the heat shields and other reusable components or replacing these components prior to safety testing of compacts from the AGR-5/6/7 irradiation test begins. 


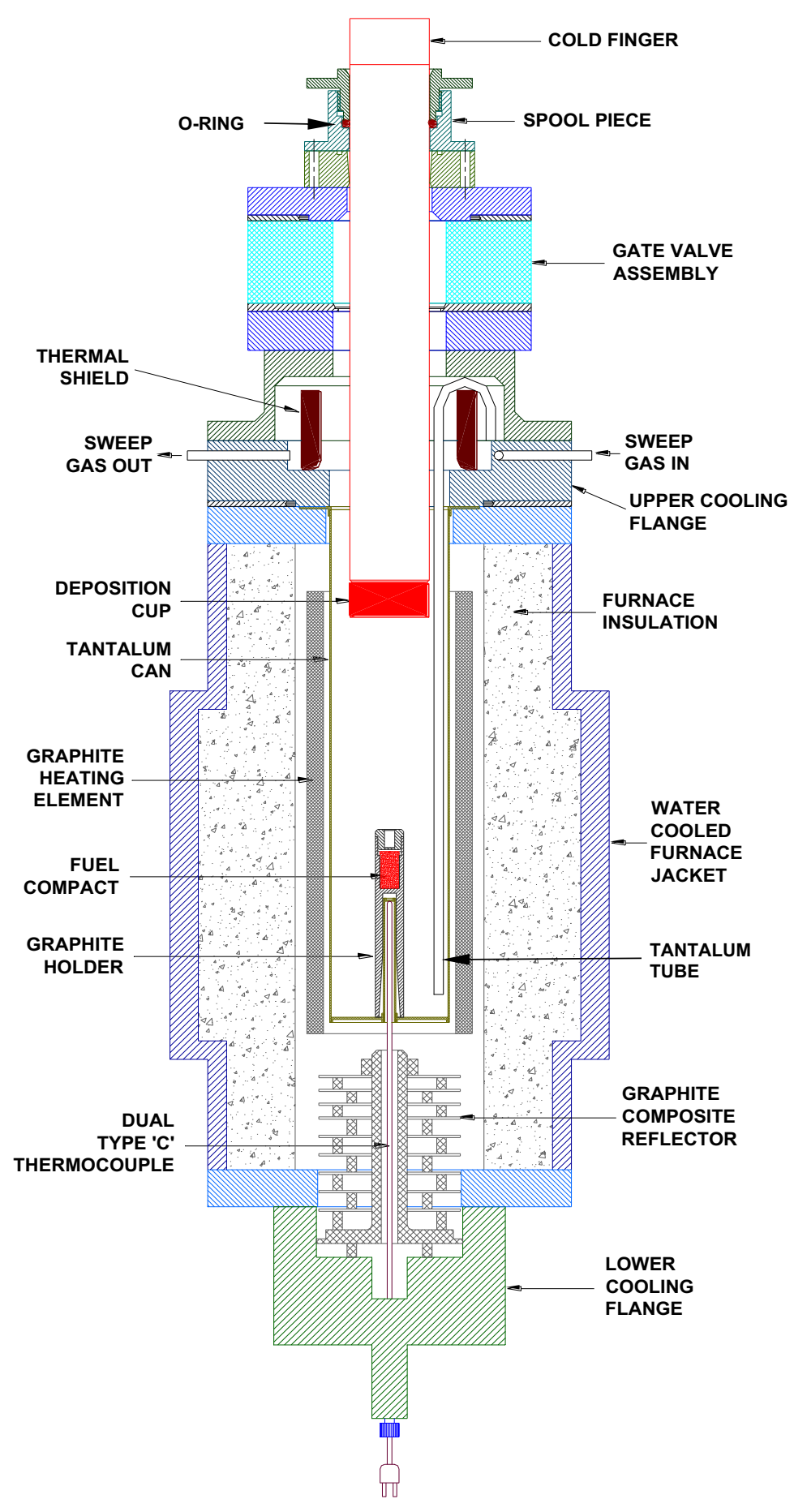

Figure 3-2. Cross section of CCCTF furnace.

The ${ }^{85} \mathrm{Kr}$ activity in the sweep gas trap was $<2 \%$ of one particle-equivalent and did not increase measurably during the test. The small amount of activity may have come from krypton sequestered in the matrix and/or OPyC of the irradiated compact, but it was too low to have come from a particle with failed TRISO. The fact that ${ }^{85} \mathrm{Kr}$ activity did not increase during the test also indicates the absence of failed SiC, because failed $\mathrm{SiC}$ particles usually release a small measurable fraction of krypton at $1,800^{\circ} \mathrm{C}$ (Morris et al. 2014). 


\subsection{SILVER RELEASE DURING SAFETY TESTING}

Silver release was consistent with previous observations of initial release during heating of silver sequestered in the matrix and/or OPyC followed by subsequent measurable release from silver diffusing through intact $\mathrm{SiC}$ at $1,800^{\circ} \mathrm{C}$. Figure 3-1 shows an initial ${ }^{110 \mathrm{~m}} \mathrm{Ag}$ release during heating to $1,250^{\circ} \mathrm{C}$ of $0.16 \%$ of the calculated compact inventory, which is relatively low compared to other AGR safety tests. For AGR-1 safety tests, ${ }^{110 \mathrm{~m}} \mathrm{Ag}$ release $\sim 24 \mathrm{~h}$ after reaching test temperature was $0.3-34 \%$ (Morris et al. 2014). For AGR-2 safety tests, ${ }^{110 \mathrm{~m}} \mathrm{Ag}$ release $\sim 24 \mathrm{~h}$ after reaching test temperature has thus far been 0.16-2.1\%. There was still significant ${ }^{110 \mathrm{~m}} \mathrm{Ag}$ remaining in Compact 6-4-3 after irradiation, 58.5\% (Harp 2016), so the low release during heating indicates that very little that diffused through SiC during irradiation remained in the matrix and/or OPyC. While there was no measurable additional release during the first $50 \mathrm{~h}$ at $1,800^{\circ} \mathrm{C}$, after this initial soak time, ${ }^{110 \mathrm{~m}} \mathrm{Ag}$ began to be collected on the deposition cups at an ever increasing rate, as shown in Figure 3-3, reaching a final release fraction of 2.6\% (Table 3-1). This clearly indicates that diffusion of silver was occurring at $1,800^{\circ} \mathrm{C}$.

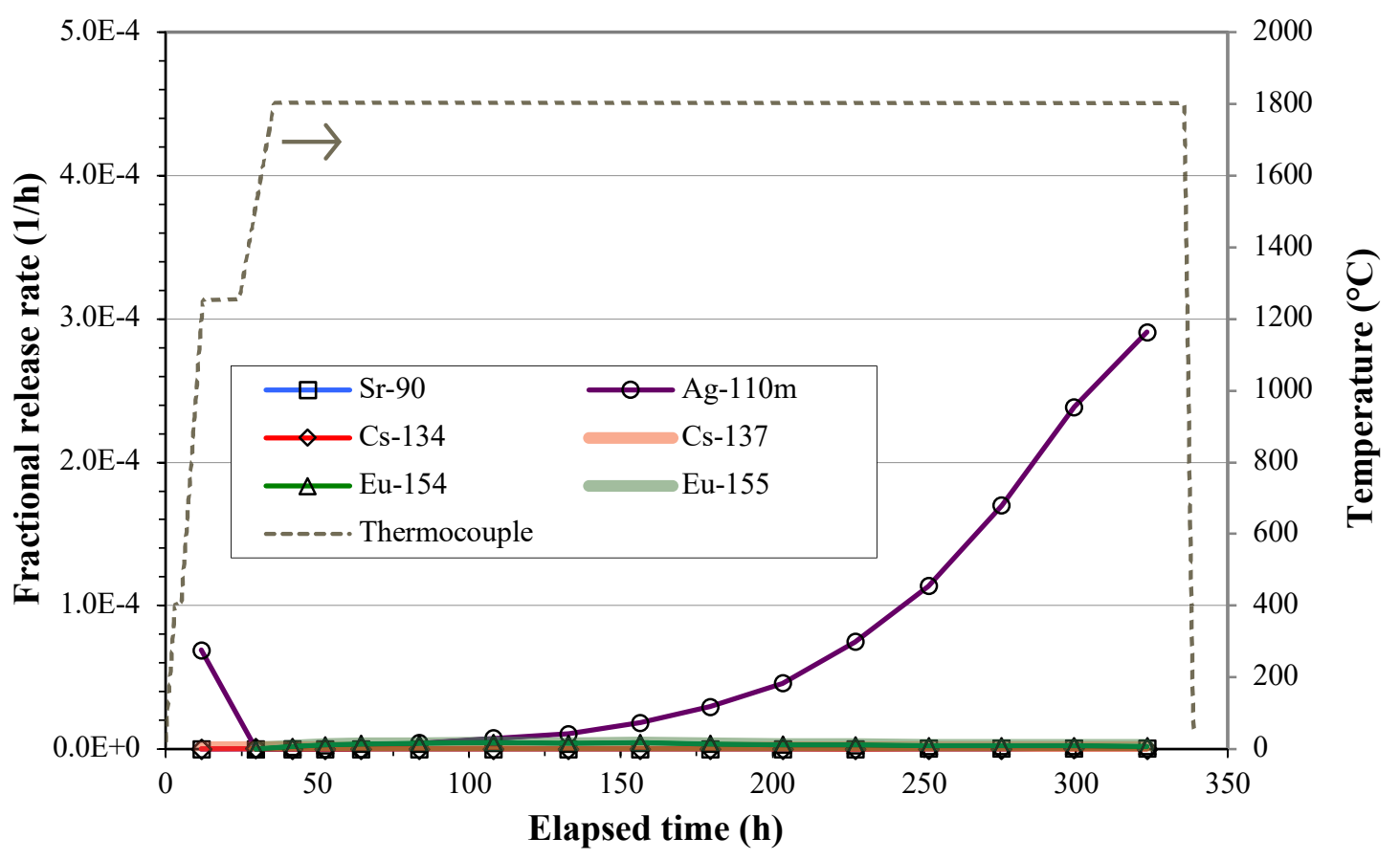

Figure 3-3. Rate of fission product release from Compact 6-4-3 during safety testing to $1,800^{\circ} \mathrm{C}$.

\subsection{STRONTIUM, EUROPIUM, AND PALLADIUM RELEASE DURING SAFETY TESTING}

The total ${ }^{90} \mathrm{Sr}$ release (5.4E-5) was relatively low compared to most AGR-1 tests, which ranged from $1.1 \mathrm{E}-5$ to $1.2 \mathrm{E}-2$ (Morris et al. 2014). There was a slight increase in the ${ }^{90} \mathrm{Sr}$ release rate after $\sim 200 \mathrm{~h}$ at $1,800^{\circ} \mathrm{C}$ which could indicate minor diffusive release through the $\mathrm{SiC}$ (Figure 3-4). Total ${ }^{154} \mathrm{Eu}$ release from Compact 6-4-3 (9.5E-4) was significantly higher than the strontium release and in the median range of what was observed in AGR-1 safety testing (2.4E-4-1.8E-2). The europium collection rate gradually decreased after $\sim 100 \mathrm{~h}$ at temperature. This was probably due to depletion of the amount of europium in the matrix and/or OPyC. There was no obvious indication for diffusive release of europium through the $\mathrm{SiC}$ in the available data, but minor diffusion similar to that apparent for strontium would have been swamped by the larger release from europium already in the matrix and/or OPyC. The total europium and strontium releases from the $1,800^{\circ} \mathrm{C}$ safety test of Compact 6-4-3 were significantly lower than the AGR-1 tests at $1,800^{\circ} \mathrm{C}$, which all showed $\sim 1 \mathrm{E}-2$ release of both ${ }^{90} \mathrm{Sr}$ and ${ }^{154} \mathrm{Eu}$. This suggests that the lower temperature, lower burnup conditions experienced by Compact 6-4-3 resulted in a more retentive $\mathrm{SiC}$ layer. Total palladium release from Compact 6-4-3 was similar in magnitude to the release of 
europium. However, because it is difficult to isolate and measure palladium release, only two deposition cups had resolvable content, so no release rate data are available.

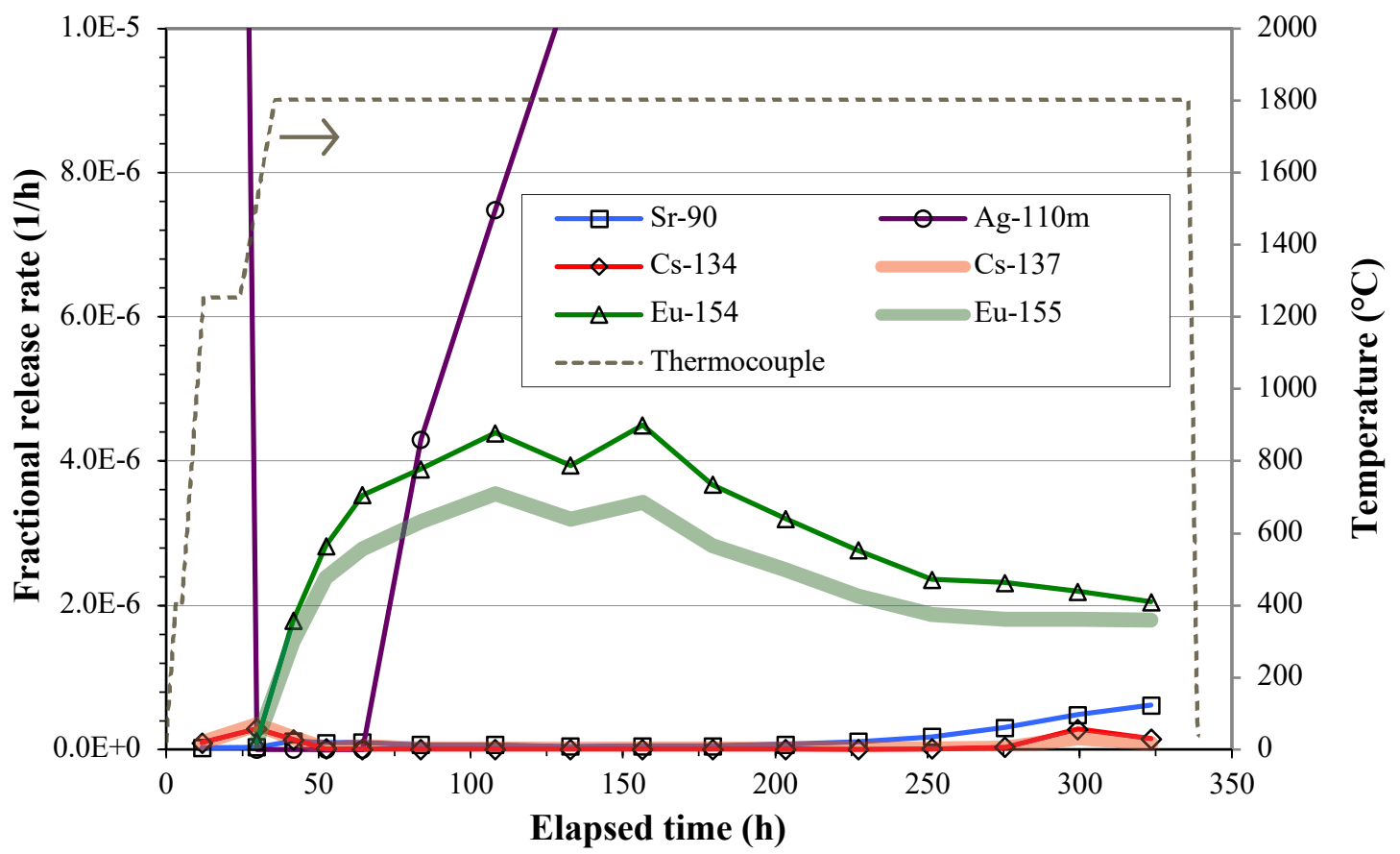

Figure 3-4. Rate of fission product release from Compact 6-4-3 during safety testing to $1,800^{\circ} \mathrm{C}$. 


\section{DECONSOLIDATION AND LEACH-BURN-LEACH ANALYSIS}

Electrolytic deconsolidation and acid leaching were performed after safety testing to recover the particles for IMGA survey and analyze for exposed fission products remaining in the compact. Table 4-1 shows several isotopes of uranium and plutonium that were detected in the acid solutions. Negligible amounts of uranium were collected in the deconsolidation acid, in the pre-burn leach of the particles and matrix, and in the post-burn leach of the matrix. This indicates that no kernels were exposed in the safety tested compact, which is consistent with the conclusion from the low ${ }^{85} \mathrm{Kr}$ release during safety testing that there were no particles with failed TRISO. The amounts of exposed plutonium in these leaches were higher than uranium, indicating that there was a slightly higher diffusive release of plutonium during irradiation and/or safety testing. The generally low levels in the deconsolidation acid, the pre-burn leach of the particles and matrix, and the post-burn leach of the matrix of the isotopes shown in Table 4-2 and Table 4-3 support the conclusion that there was no TRISO failure in Compact 6-4-3.

There were $\sim 6-8$ particle-equivalents of uranium and plutonium detected in the first post-burn leach of the particles (Table 4-1). The variability in the exposed compact inventory fractions for these isotopes was likely related to error in the calculated inventories. The uranium and plutonium detected in the first post-burn leach most likely came from individual exposed kernels that were fractured during IMGA survey rather than particles with failed SiC. Compact 6-4-3 was analyzed prior to replacement of the IMGA translation stages in February 2019. Onset of mechanical failure of the translation stages resulted in several events in which the IMGA vacuum needle was driven past the programmed position, resulting in particle damage. Table 4-2 and Table 4-3 show similar evidence for $\sim 6$ exposed kernels in the particles subjected to burn-leach after IMGA survey. Figure 5-7 and Figure 5-8 are discussed in the Section 5.1, and they show particles not included in the particle burn-leach that would have leached uranium due to broken TRISO coatings if they had been included.

Table 4-1. Exposed U and Pu detected by DLBL

\begin{tabular}{lccccc}
\hline DLBL step & ${ }^{235} \mathbf{U}$ & ${ }^{236} \mathbf{U}$ & ${ }^{238} \mathbf{U}$ & ${ }^{239} \mathbf{P u}$ & ${ }^{240} \mathbf{P u}$ \\
\hline \multirow{2}{*}{ Deconsolidation acid } & $3.15 \mathrm{E}-6$ & $3.79 \mathrm{E}-6$ & $7.29 \mathrm{E}-6$ & $2.41 \mathrm{E}-5$ & $2.72 \mathrm{E}-5$ \\
& $(0.010)$ & $(0.012)$ & $(0.023)$ & $(0.077)$ & $(0.086)$ \\
Pre-burn leach 1 & $1.94 \mathrm{E}-6$ & $2.20 \mathrm{E}-6$ & $3.38 \mathrm{E}-6$ & $2.56 \mathrm{E}-5$ & $2.92 \mathrm{E}-5$ \\
& $(0.006)$ & $(0.007)$ & $(0.011)$ & $(0.081)$ & $(0.093)$ \\
Pre-burn leach 2 & $9.32 \mathrm{E}-7$ & $2.34 \mathrm{E}-6$ & $7.02 \mathrm{E}-6$ & $6.45 \mathrm{E}-6$ & $1.09 \mathrm{E}-5$ \\
& $(0.003)$ & $(0.007)$ & $(0.022)$ & $(0.020)$ & $(0.035)$ \\
Post-burn matrix leach 1 & $2.87 \mathrm{E}-6$ & $7.02 \mathrm{E}-6$ & $2.03 \mathrm{E}-5$ & $3.84 \mathrm{E}-5$ & $5.11 \mathrm{E}-5$ \\
& $(0.009)$ & $(0.022)$ & $(0.065)$ & $(0.122)$ & $(0.162)$ \\
Post-burn matrix leach 2 & $9.12 \mathrm{E}-8$ & $2.85 \mathrm{E}-7$ & $7.18 \mathrm{E}-7$ & $9.01 \mathrm{E}-7$ & $1.84 \mathrm{E}-6$ \\
& $(0.0003)$ & $(0.0009)$ & $(0.002)$ & $(0.003)$ & $(0.006)$ \\
Post-burn particle leach 1 & $2.65 \mathrm{E}-3$ & $2.02 \mathrm{E}-3$ & $2.63 \mathrm{E}-3$ & $2.49 \mathrm{E}-3$ & $1.90 \mathrm{E}-3$ \\
& $(8.421)$ & $(6.422)$ & $(8.339)$ & $(7.902)$ & $(6.046)$ \\
Post-burn particle leach 2 & $4.90 \mathrm{E}-6$ & $5.27 \mathrm{E}-6$ & $7.74 \mathrm{E}-6$ & $4.33 \mathrm{E}-5$ & $4.69 \mathrm{E}-5$ \\
& $(0.016)$ & $(0.017)$ & $(0.025)$ & $(0.137)$ & $(0.149)$ \\
\hline \multirow{2}{*}{ Total } & $2.67 \mathrm{E}-3$ & $2.04 \mathrm{E}-3$ & $2.67 \mathrm{E}-3$ & $2.63 \mathrm{E}-3$ & $2.07 \mathrm{E}-3$ \\
& $(8.46)$ & $(6.49)$ & $(8.49)$ & $(8.34)$ & $(6.58)$ \\
\hline
\end{tabular}

Note: Values are reported as compact inventory fraction and equivalent-particle inventory (in parentheses).

Note: Values that primarily contributed to the total for each isotope are highlighted.

${ }^{a}$ Because exposed kernels dominated the post-burn particle leach results, no scaling factor was applied to account for $\sim 558$ out of $\sim 3,176$ particles not included in the analysis. 
Table 4-2. Exposed compact inventory fractions ${ }^{a}$ of typically tracked beta/gamma-emitting fission products detected by DLBL

\begin{tabular}{|c|c|c|c|c|c|c|c|c|c|}
\hline DLBL step & ${ }^{90} \mathrm{Sr}^{a}$ & ${ }^{106} \mathbf{R u}$ & ${ }^{110 m} \mathrm{Ag}$ & ${ }^{125} \mathrm{Sb}$ & ${ }^{134} \mathrm{Cs}$ & ${ }^{137} \mathrm{Cs}$ & ${ }^{144} \mathrm{Ce}$ & ${ }^{154} \mathbf{E u}$ & ${ }^{155} \mathbf{E u}$ \\
\hline Deconsolidation acid & $\begin{array}{c}6.81 \mathrm{E}-6 \\
(0.022)\end{array}$ & $\begin{array}{c}<1.86 \mathrm{E}-6 \\
(<0.006)\end{array}$ & $\begin{array}{c}<4.65 \mathrm{E}-4 \\
(<1.48)\end{array}$ & $\begin{array}{c}<3.26 \mathrm{E}-6 \\
(<0.010)\end{array}$ & $\begin{array}{c}1.47 \mathrm{E}-7 \\
(0.0005)\end{array}$ & $\begin{array}{c}2.61 \mathrm{E}-6 \\
(0.008)\end{array}$ & $\begin{array}{c}6.39 \mathrm{E}-6 \\
(0.020)\end{array}$ & $\begin{array}{l}1.06 \mathrm{E}-5 \\
(0.034)\end{array}$ & $\begin{array}{c}9.64 \mathrm{E}-6 \\
(0.031)\end{array}$ \\
\hline Pre-burn leach 1 & $\begin{array}{c}3.46 \mathrm{E}-6 \\
(0.011)\end{array}$ & $\begin{array}{c}<1.55 \mathrm{E}-6 \\
(<0.005)\end{array}$ & $\begin{array}{c}<5.28 \mathrm{E}-4 \\
(<1.68)\end{array}$ & $\begin{array}{c}<2.64 \mathrm{E}-6 \\
(<0.008)\end{array}$ & $\begin{array}{l}2.26 \mathrm{E}-7 \\
(0.0007)\end{array}$ & $\begin{array}{c}1.36 \mathrm{E}-6 \\
(0.004)\end{array}$ & $\begin{array}{c}1.17 \mathrm{E}-5 \\
(0.037)\end{array}$ & $\begin{array}{c}1.28 \mathrm{E}-5 \\
(0.041)\end{array}$ & $\begin{array}{c}1.31 \mathrm{E}-5 \\
(0.042)\end{array}$ \\
\hline Pre-burn leach 2 & $\begin{array}{c}4.15 \mathrm{E}-6 \\
(0.013)\end{array}$ & $\begin{array}{c}<3.83 \mathrm{E}-6 \\
(<0.012)\end{array}$ & $\begin{array}{c}<1.05 \mathrm{E}-3 \\
(<3.35)\end{array}$ & $\begin{array}{c}<7.39 \mathrm{E}-6 \\
(<0.023)\end{array}$ & $\begin{array}{c}6.62 \mathrm{E}-7 \\
(0.0021)\end{array}$ & $\begin{array}{c}6.91 \mathrm{E}-6 \\
(0.022)\end{array}$ & $\begin{array}{c}1.57 \mathrm{E}-6 \\
(0.005)\end{array}$ & $\begin{array}{c}7.38 \mathrm{E}-6 \\
(0.023)\end{array}$ & $\begin{array}{c}<5.12 \mathrm{E}-6 \\
(<0.016)\end{array}$ \\
\hline Post-burn matrix leach 1 & $\begin{array}{l}1.39 \mathrm{E}-5 \\
(0.044)\end{array}$ & $\begin{array}{c}5.39 \mathrm{E}-6 \\
(0.017)\end{array}$ & $\begin{array}{c}<3.39 \mathrm{E}-4 \\
(<1.08)\end{array}$ & $\begin{array}{c}<2.99 \mathrm{E}-6 \\
(<0.009)\end{array}$ & $\begin{array}{l}1.22 \mathrm{E}-6 \\
(0.004)\end{array}$ & $\begin{array}{c}6.61 \mathrm{E}-6 \\
(0.021)\end{array}$ & $\begin{array}{l}1.45 \mathrm{E}-5 \\
(0.046)\end{array}$ & $\begin{array}{c}2.98 \mathrm{E}-5 \\
(0.095)\end{array}$ & $\begin{array}{c}2.56 \mathrm{E}-5 \\
(0.081)\end{array}$ \\
\hline Post-burn matrix leach 2 & $\begin{array}{l}1.61 \mathrm{E}-6 \\
(0.005)\end{array}$ & $\begin{array}{c}<8.04 \mathrm{E}-7 \\
(<0.003)\end{array}$ & $\begin{array}{c}<2.23 \mathrm{E}-4 \\
(<0.71)\end{array}$ & $\begin{array}{c}<1.47 \mathrm{E}-6 \\
(<0.005)\end{array}$ & $\begin{array}{c}1.38 \mathrm{E}-7 \\
(0.0004)\end{array}$ & $\begin{array}{c}9.97 \mathrm{E}-7 \\
(0.003)\end{array}$ & $\begin{array}{c}1.90 \mathrm{E}-7 \\
(0.0006)\end{array}$ & $\begin{array}{c}<1.69 \mathrm{E}-6 \\
(<0.005)\end{array}$ & $\begin{array}{l}<1.37 \mathrm{E}-6 \\
(<0.004)\end{array}$ \\
\hline Post-burn particle leach $1^{b}$ & $\begin{array}{l}1.92 \mathrm{E}-3 \\
(6.107)\end{array}$ & $\begin{array}{c}2.29 \mathrm{E}-4 \\
(0.727)\end{array}$ & $\begin{array}{c}<7.02 \mathrm{E}-3 \\
(<22.3)\end{array}$ & $\begin{array}{c}6.69 \mathrm{E}-4 \\
(2.125)\end{array}$ & $\begin{array}{c}1.37 \mathrm{E}-3 \\
(4.348)\end{array}$ & $\begin{array}{l}1.84 \mathrm{E}-3 \\
(5.836)\end{array}$ & $\begin{array}{c}2.09 \mathrm{E}-3 \\
(6.624)\end{array}$ & $\begin{array}{l}1.35 \mathrm{E}-3 \\
(4.279)\end{array}$ & $\begin{array}{c}1.61 \mathrm{E}-3 \\
(5.122)\end{array}$ \\
\hline Post-burn particle leach $2^{b}$ & $\begin{array}{c}7.10 \mathrm{E}-6 \\
(0.023)\end{array}$ & $\begin{array}{c}3.57 \mathrm{E}-5 \\
(0.113)\end{array}$ & $\begin{array}{c}<1.69 \mathrm{E}-3 \\
(<5.38)\end{array}$ & $\begin{array}{c}4.98 \mathrm{E}-5 \\
(0.158)\end{array}$ & $\begin{array}{c}3.07 \mathrm{E}-5 \\
(0.098)\end{array}$ & $\begin{array}{c}3.99 \mathrm{E}-5 \\
(0.127)\end{array}$ & $\begin{array}{c}2.38 \mathrm{E}-5 \\
(0.076)\end{array}$ & $\begin{array}{c}2.43 \mathrm{E}-5 \\
(0.077)\end{array}$ & $\begin{array}{c}2.28 \mathrm{E}-5 \\
(0.072)\end{array}$ \\
\hline Total & $\begin{array}{c}1.96 \mathrm{E}-3 \\
(6.22)\end{array}$ & $\begin{array}{c}2.70 \mathrm{E}-4 \\
(0.86)\end{array}$ & $\begin{array}{c}<7.02 \mathrm{E}-3 \\
(<22.3)\end{array}$ & $\begin{array}{c}7.19 \mathrm{E}-4 \\
(2.28)\end{array}$ & $\begin{array}{c}1.40 \mathrm{E}-3 \\
(4.45)\end{array}$ & $\begin{array}{c}1.90 \mathrm{E}-3 \\
(6.02)\end{array}$ & $\begin{array}{c}2.14 \mathrm{E}-3 \\
(6.81)\end{array}$ & $\begin{array}{c}1.43 \mathrm{E}-3 \\
(4.55)\end{array}$ & $\begin{array}{c}1.68 \mathrm{E}-3 \\
(5.35)\end{array}$ \\
\hline
\end{tabular}

Note: Values are reported as compact inventory fraction and equivalent-particle inventory (in parentheses).

Note: Values that primarily contributed to the total for each isotope are highlighted.

Note: A less-than value indicates that the concentration in the leachate was below the minimum detectable limit; these values are not included in the totals.

${ }^{a}$ Chemical separation and beta analysis were used to measure ${ }^{90} \mathrm{Sr}$; other isotopes were measured by gamma spectrometry.

${ }^{b}$ Because exposed kernels dominated the post-burn particle leach results, no scaling factor was applied to account for $\sim 558$ out of $\sim 3,176$ particles not included in the analysis. 
Table 4-3. Exposed compact inventory fractions ${ }^{a}$ of stable isotopes of interest detected by DLBL

\begin{tabular}{lcccccccccc}
\hline LBL step & ${ }^{105} \mathbf{P d}$ & ${ }^{109} \mathbf{A g}$ & ${ }^{133} \mathbf{C s}$ & ${ }^{139} \mathbf{L a}$ & ${ }^{140} \mathbf{C e}$ & ${ }^{141} \mathbf{P r}$ & ${ }^{146} \mathbf{N d}$ & ${ }^{152} \mathbf{S m}$ & ${ }^{153} \mathbf{E u}$ & ${ }^{156} \mathbf{G d}$ \\
\hline \multirow{2}{*}{ Deconsolidation acid } & $<2.40 \mathrm{E}-5$ & $1.33 \mathrm{E}-4$ & $3.92 \mathrm{E}-6$ & $6.18 \mathrm{E}-5$ & $4.89 \mathrm{E}-5$ & $1.57 \mathrm{E}-5$ & $1.24 \mathrm{E}-5$ & $1.89 \mathrm{E}-5$ & $4.11 \mathrm{E}-5$ & $2.11 \mathrm{E}-4$ \\
& $(<0.076)$ & $(0.423)$ & $(0.012)$ & $(0.196)$ & $(0.155)$ & $(0.050)$ & $(0.039)$ & $(0.060)$ & $(0.130)$ & $(0.669)$ \\
Pre-burn leach 1 & $<3.35 \mathrm{E}-5$ & $2.62 \mathrm{E}-4$ & $2.74 \mathrm{E}-6$ & $1.04 \mathrm{E}-4$ & $1.11 \mathrm{E}-4$ & $2.15 \mathrm{E}-5$ & $1.65 \mathrm{E}-5$ & $3.69 \mathrm{E}-5$ & $3.79 \mathrm{E}-5$ & $4.29 \mathrm{E}-4$ \\
& $(<0.106)$ & $(0.831)$ & $(0.009)$ & $(0.329)$ & $(0.352)$ & $(0.068)$ & $(0.052)$ & $(0.117)$ & $(0.120)$ & $(1.363)$ \\
Pre-burn leach 2 & $<5.13 \mathrm{E}-5$ & $8.82 \mathrm{E}-5$ & $8.97 \mathrm{E}-6$ & $2.26 \mathrm{E}-5$ & $2.83 \mathrm{E}-5$ & $1.10 \mathrm{E}-5$ & $1.11 \mathrm{E}-5$ & $<1.67 \mathrm{E}-5$ & $3.36 \mathrm{E}-5$ & $1.73 \mathrm{E}-4$ \\
& $(<0.163)$ & $(0.280)$ & $(0.028)$ & $(0.072)$ & $(0.090)$ & $(0.035)$ & $(0.035)$ & $(<0.053)$ & $(0.107)$ & $(0.549)$ \\
Post-burn matrix leach 1 & $<1.51 \mathrm{E}-5$ & $1.03 \mathrm{E}-4$ & $9.12 \mathrm{E}-6$ & $1.22 \mathrm{E}-4$ & $1.34 \mathrm{E}-4$ & $3.40 \mathrm{E}-5$ & $2.90 \mathrm{E}-5$ & $3.00 \mathrm{E}-5$ & $8.16 \mathrm{E}-5$ & $4.18 \mathrm{E}-4$ \\
& $(<0.048)$ & $(0.328)$ & $(0.029)$ & $(0.389)$ & $(0.427)$ & $(0.108)$ & $(0.092)$ & $(0.095)$ & $(0.259)$ & $(1.328)$ \\
Post-burn matrix leach 2 & $<1.84 \mathrm{E}-5$ & $<2.44 \mathrm{E}-5$ & $1.22 \mathrm{E}-6$ & $3.12 \mathrm{E}-6$ & $8.95 \mathrm{E}-6$ & $1.08 \mathrm{E}-6$ & $1.15 \mathrm{E}-6$ & $<6.02 \mathrm{E}-6$ & $<1.11 \mathrm{E}-5$ & $<3.39 \mathrm{E}-5$ \\
& $(<0.059)$ & $(<0.077)$ & $(0.004)$ & $(0.010)$ & $(0.028)$ & $(0.003)$ & $(0.004)$ & $(<0.019)$ & $(<0.035)$ & $(<0.108)$ \\
Post-burn particle leach 1 ${ }^{a}{ }^{a}$ & $1.14 \mathrm{E}-4$ & $1.46 \mathrm{E}-3$ & $1.67 \mathrm{E}-3$ & $2.03 \mathrm{E}-3$ & $1.93 \mathrm{E}-3$ & $1.86 \mathrm{E}-3$ & $1.59 \mathrm{E}-3$ & $1.75 \mathrm{E}-3$ & $1.63 \mathrm{E}-3$ & $3.53 \mathrm{E}-3$ \\
& $(0.361)$ & $(4.641)$ & $(5.309)$ & $(6.460)$ & $(6.139)$ & $(5.906)$ & $(5.054)$ & $(5.555)$ & $(5.184)$ & $(11.222)$ \\
Post-burn particle leach 2 ${ }^{a}$ & $<3.85 \mathrm{E}-5$ & $8.42 \mathrm{E}-5$ & $3.83 \mathrm{E}-5$ & $1.42 \mathrm{E}-5$ & $3.27 \mathrm{E}-5$ & $1.11 \mathrm{E}-5$ & $1.08 \mathrm{E}-5$ & $1.35 \mathrm{E}-5$ & $4.31 \mathrm{E}-5$ & $1.09 \mathrm{E}-4$ \\
& $(<0.122)$ & $(0.267)$ & $(0.122)$ & $(0.045)$ & $(0.104)$ & $(0.035)$ & $(0.034)$ & $(0.043)$ & $(0.137)$ & $(0.345)$ \\
\hline \multirow{2}{*}{ Total } & $1.14 \mathrm{E}-4$ & $2.13 \mathrm{E}-3$ & $1.74 \mathrm{E}-3$ & $2.36 \mathrm{E}-3$ & $2.30 \mathrm{E}-3$ & $1.95 \mathrm{E}-3$ & $1.67 \mathrm{E}-3$ & $1.85 \mathrm{E}-3$ & $1.87 \mathrm{E}-3$ & $4.87 \mathrm{E}-3$ \\
& $(0.36)$ & $(6.77)$ & $(5.51)$ & $(7.50)$ & $(7.30)$ & $(6.21)$ & $(5.31)$ & $(5.87)$ & $(5.94)$ & $(15.48)$ \\
\hline
\end{tabular}

Note: Values are reported as compact inventory fraction and equivalent-particle inventory (in parentheses).

Note: Values that primarily contributed to the total for each isotope are highlighted.

Note: A less-than value indicates that the concentration in the leachate was below the minimum detectable limit; these values are not included in the totals.

${ }^{a}$ Because exposed kernels dominated the post-burn particle leach results, no scaling factor was applied to account for $\sim 558$ out of $\sim 3,176$ particles not included in the analysis. 


\section{IMGA MEASUREMENTS}

\subsection{IMGA SURVEY OF DECONSOLIDATED TRISO PARTICLES}

Figure 5-1 is a histogram of the ${ }^{137} \mathrm{Cs}$ activity in each particle surveyed with IMGA normalized by the average of all particles measured, as explained in Section 2.2. Only 2,510 particles out of an expected average population of 3,176 were successfully gamma counted because of several issues with the deconsolidation of the compact, as well as the aforementioned problems with the IMGA translational stages. Deconsolidation of Compact 6-4-3 was less complete than usual, with more undigested matrix debris adhering to and mixed with the TRISO particles. There was also one large piece from the top of the compact (around 9\% of the volume of the compact) that dropped out of the deconsolidation tube prior to complete deconsolidation. There were 2,872 individual TRISO particles recovered from the compact that were imaged and counted prior to IMGA survey. Based on the difference between this count and the average number of particles in an AGR-2 UCO compact $(3,176)$, the chunk held an estimated 304 particles, which is consistent with the rough estimate of its volume. Of the 2,872 TRISO particles that were loaded into IMGA, only 2,510 single particle gamma spectra were obtained, so 362 were not counted. About 10 particles were stuck together in groups of two with undigested matrix. There were 15 recovered from locations on the IMGA where they had been dropped during particle transfer. The other estimated 337 were also dropped during particle transfer but were not recovered until the IMGA was disassembled months later. This particle handling problem was a combination of the failing IMGA components and the residual matrix debris, which caused particles to stick to each other and the vacuum needle to clog.

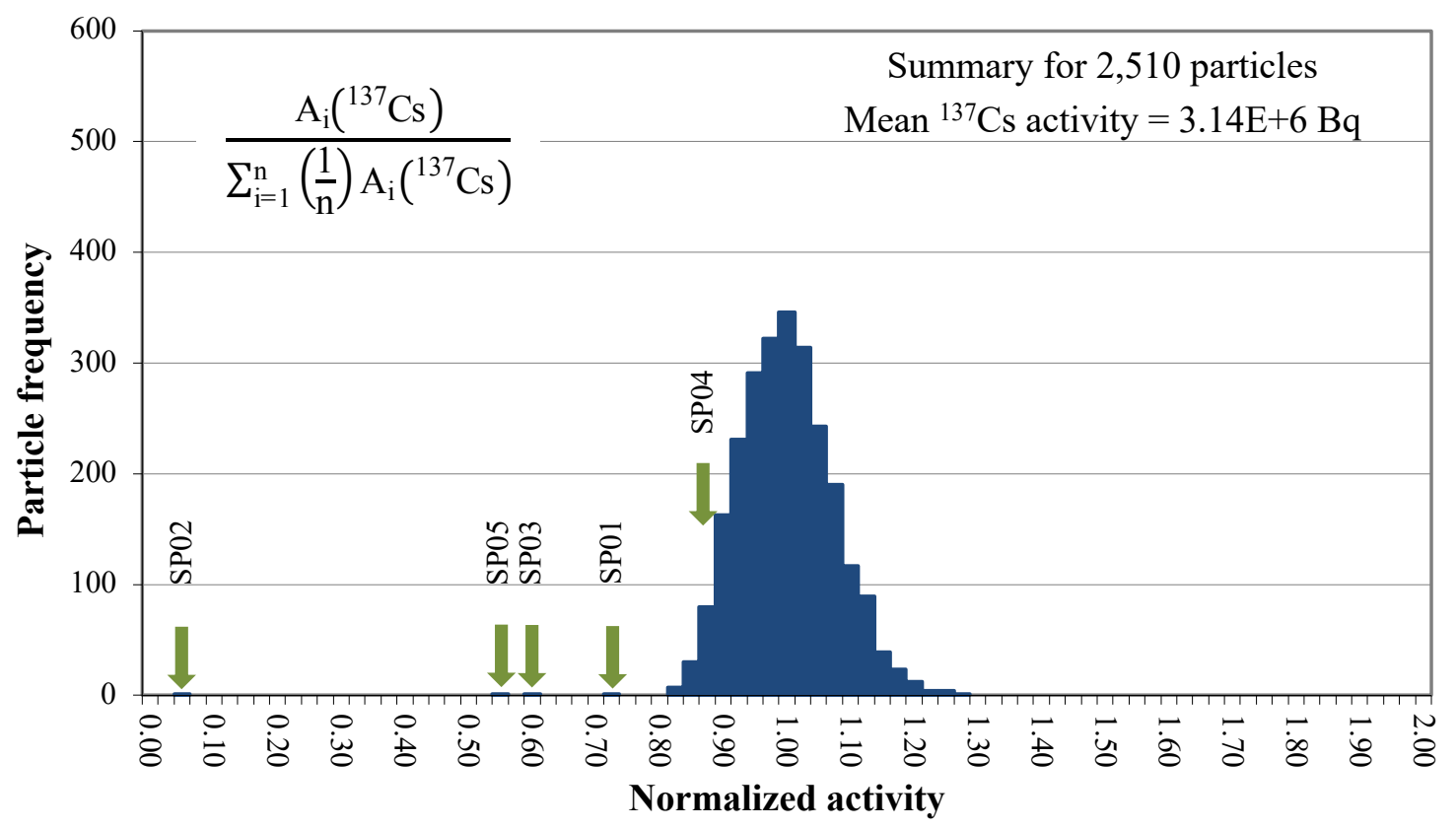

Figure 5-1. Particle distribution for measured ${ }^{137} \mathrm{Cs}$ activity normalized to the average.

The IMGA survey detected five particles with abnormal ${ }^{137} \mathrm{Cs}$ and/or ${ }^{144} \mathrm{Ce}$ inventories. Particle 643-SP05 had a normalized ${ }^{137} \mathrm{Cs}$ activity that was distinctly below the main distribution shown in Figure 5-1. However, it had a similarly reduced ${ }^{144} \mathrm{Ce}$ activity (Figure 5-2), so the measured-to-calculated ${ }^{137} \mathrm{Cs}$ ratio adjusted for variation in fissionable material, and burnup with the measured ${ }^{144} \mathrm{Ce}$ activity (i.e., the ${ }^{137} \mathrm{Cs}$ $\mathrm{M} / \mathrm{C}$, as explained in Section 2.2) was within the expected distribution for particles with good cesium retention (Figure 5-3). Because the ${ }^{137} \mathrm{Cs} /{ }^{144} \mathrm{Ce}$ ratio was within the normal range, this particle was not sorted out with the IMGA for further analysis. Presumably, this particle had an abnormally small kernel, but it did not preferentially release cesium. Particles with undersized kernels have been observed either as a result of ineffective sieving during kernel upgrading prior to coating or as a result of kernel 
fragmentation during coating, which can occur if kernels are weakened by fissures formed during nonoptimized fabrication. Figure 5-4 shows a dimpled particle found in Batch G83J-14-93073A when undersized particles were separated by rollermicrometer sorting prior to compacting (Hunn, Montgomery, and Pappano 2010a); this BWXT coater batch of TRISO particles was used to make compacts for the AGR-2 irradiation test. Figure 5-5 shows a similar dimpled particle found in Batch G83J-14-93072A; this BWXT TRISO particle batch was rejected for use in the irradiation test because of an excessive fraction of particles with unacceptable uranium dispersion. Figure 5-6 shows an x-ray tomogram of the dimpled particle shown in Figure 5-5, revealing a fractured kernel as the source of the dimple, as well as dispersed uranium at the boundary between the buffer and the inner pyrolytic carbon (IPyC) layer.

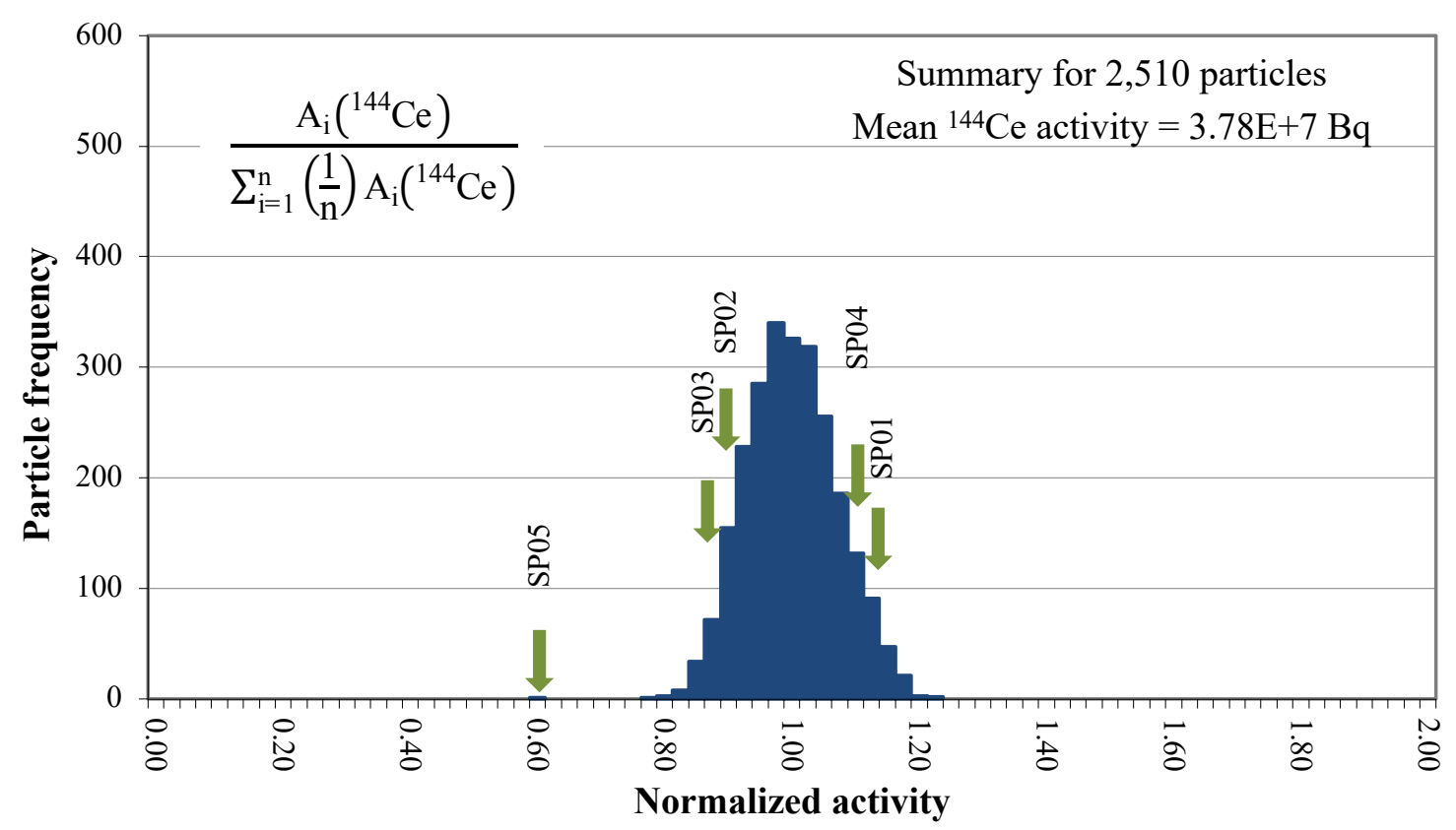

Figure 5-2. Particle distribution for measured ${ }^{144} \mathrm{Ce}$ activity normalized to the average.

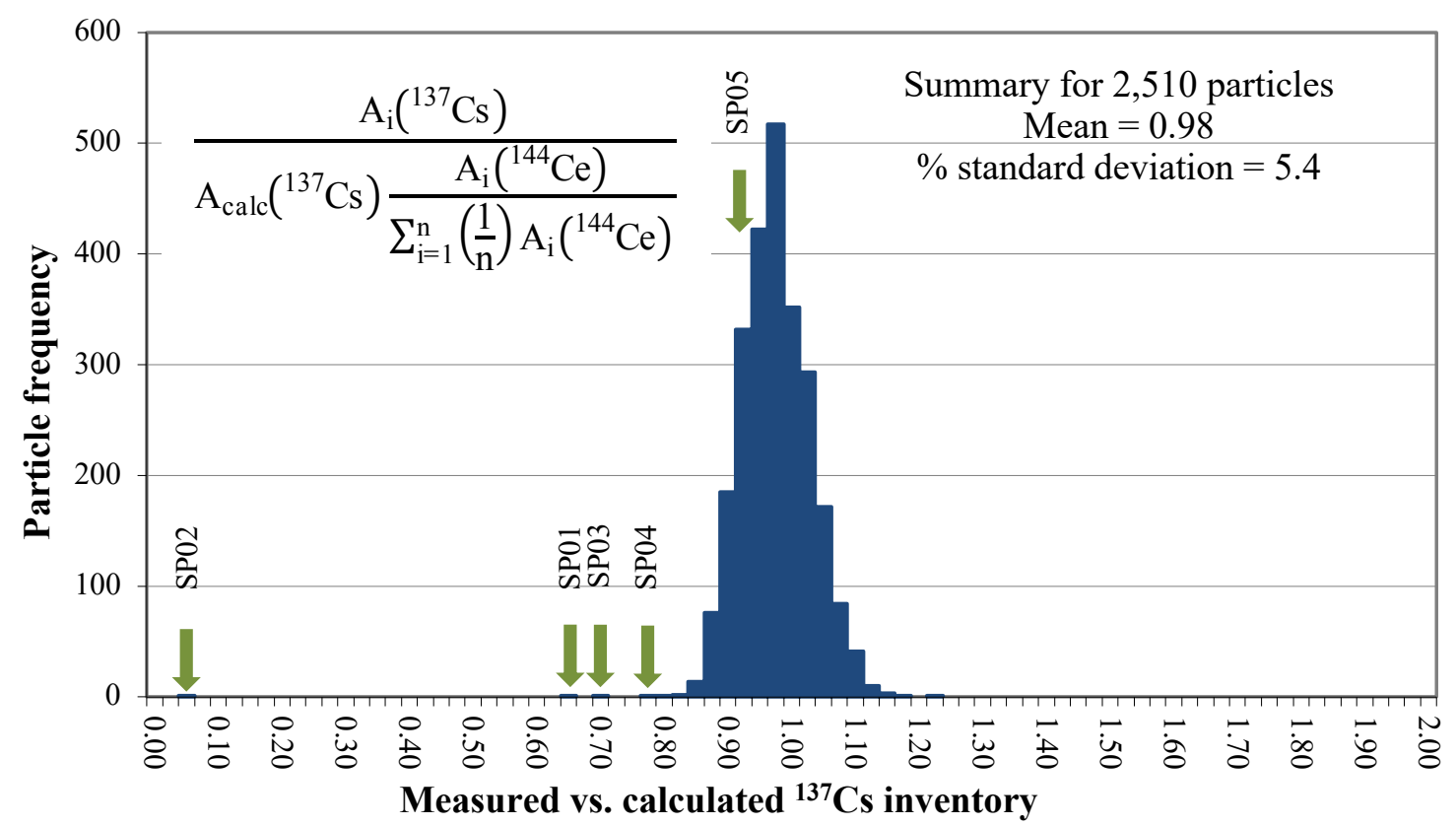

Figure 5-3. Ratio of ${ }^{137} \mathrm{Cs}$ retained in 2,510 Compact 6-4-3 particles after safety testing to $1,800^{\circ} \mathrm{C}$ vs. the calculated inventory adjusted for variation in fissionable material and burnup with the measured ${ }^{144} \mathrm{Ce}$ activity. 


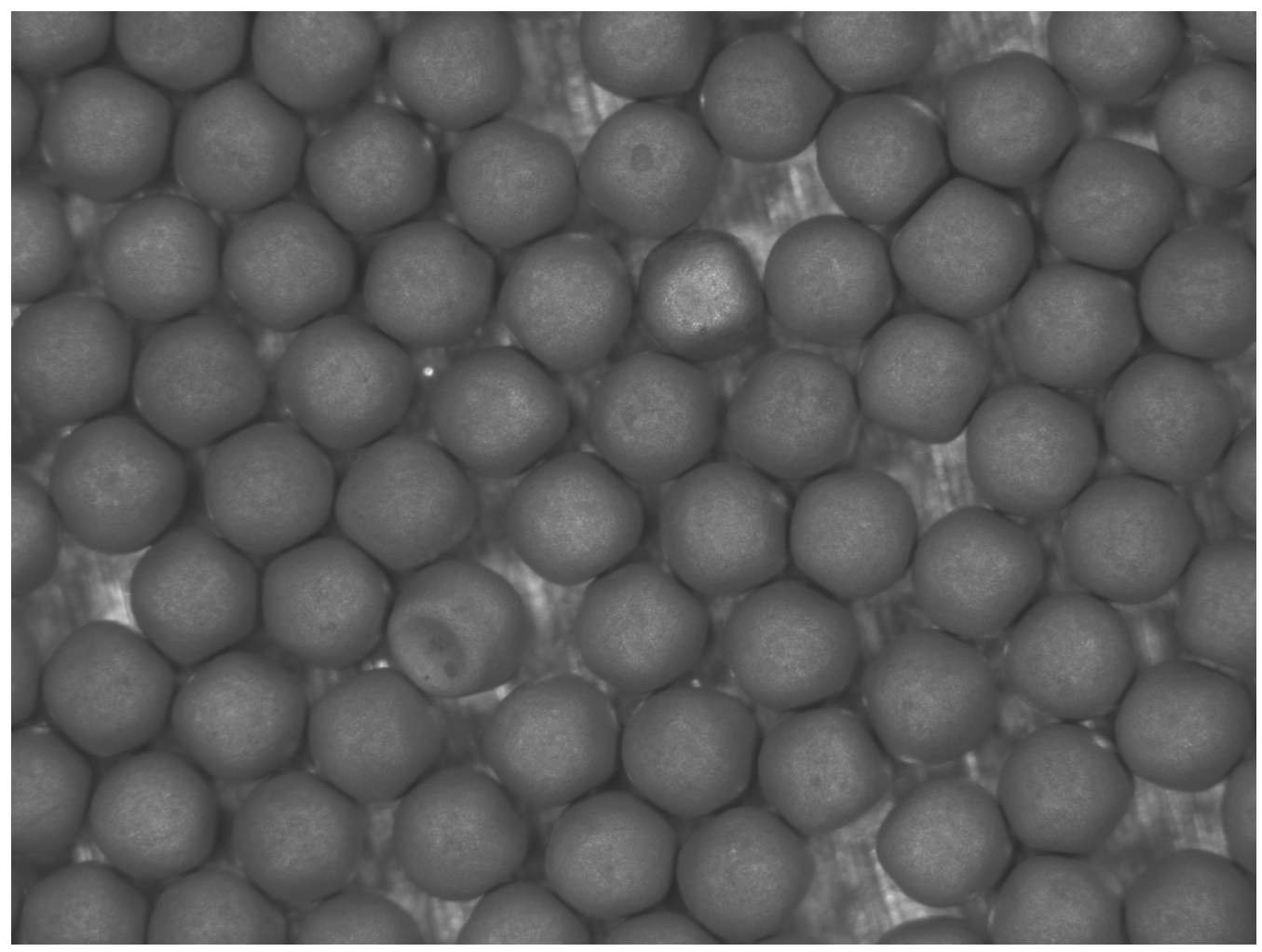

Figure 5-4. Optical micrograph showing one of the dimpled particles amid numerous undersized particles that were separated from Batch G83J-14-93073A by rollermicrometer sorting prior to compacting.

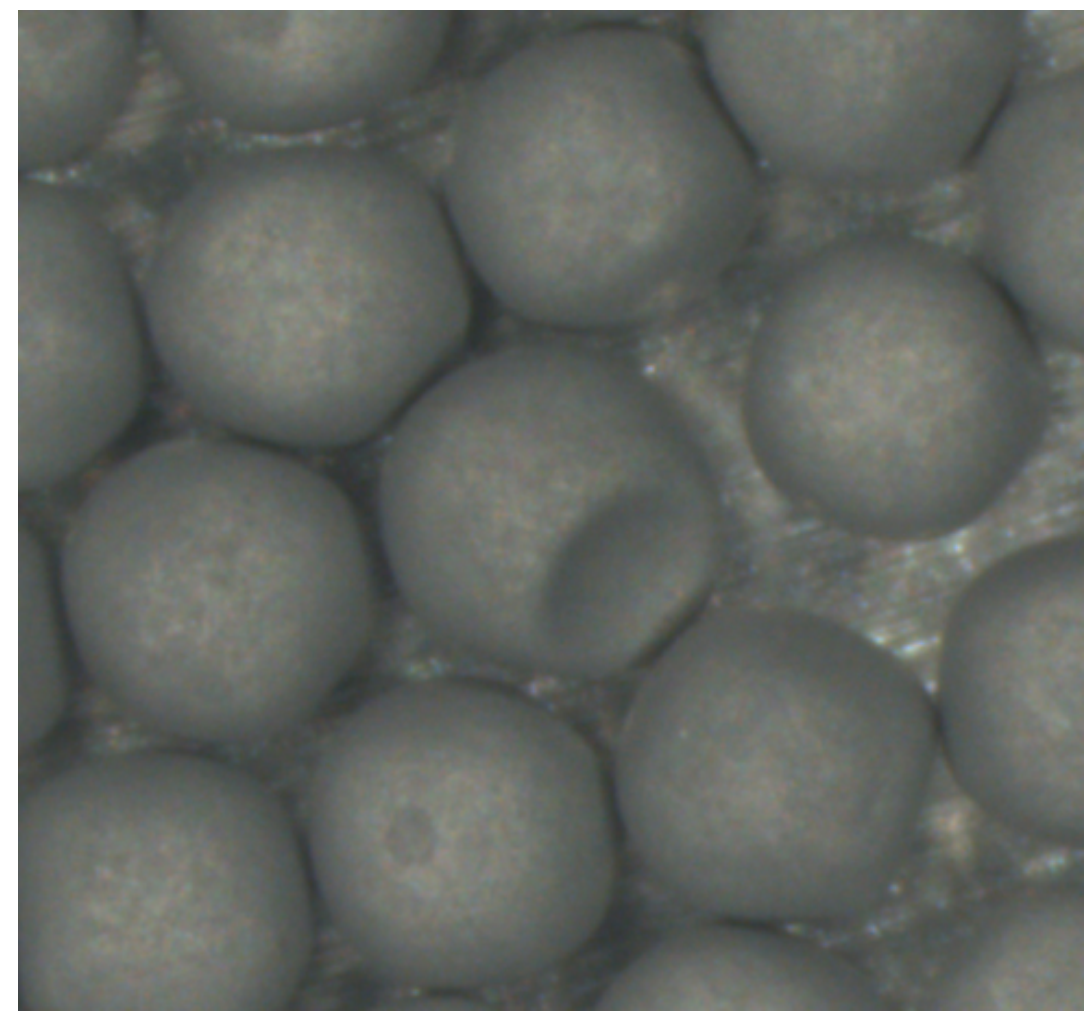

Figure 5-5. Optical micrograph showing one of the dimpled particles found in Batch G83J-14-93072A when undersized particles were separated by rollermicrometer sorting prior to compacting. 


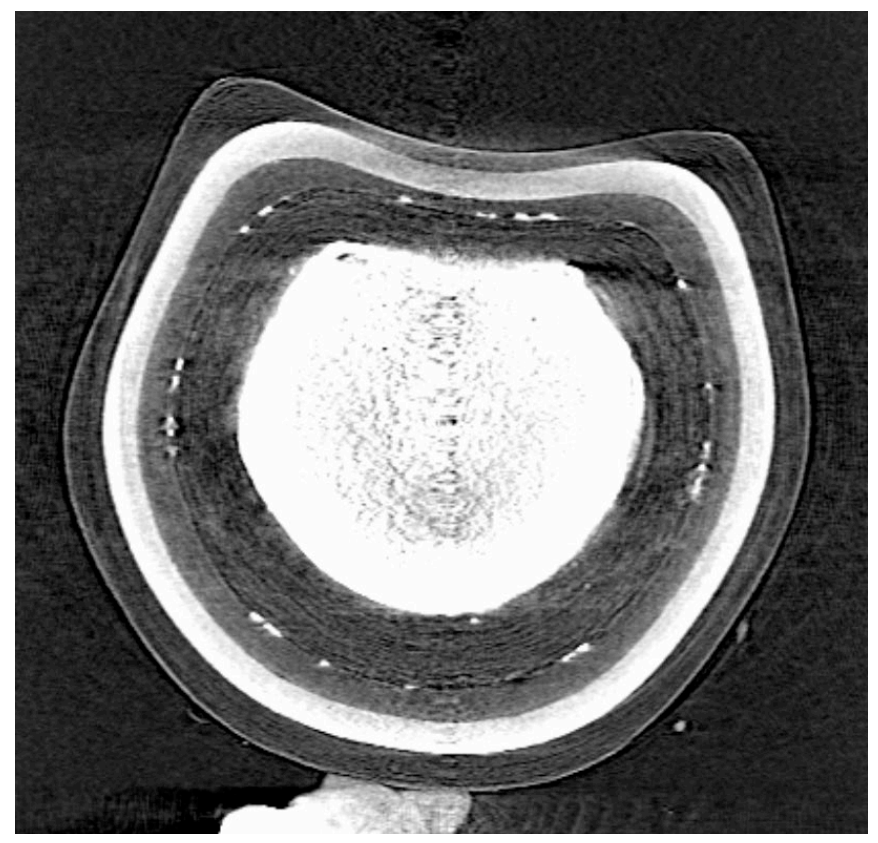

Figure 5-6. X-ray tomogram of the dimpled particle from Figure 5-5, showing that a fractured kernel was the source of the dimple (bright spots at the buffer/IPyC boundary are clusters of dispersed uranium).

Four Compact 6-4-3 particles (643-SP01, 643-SP02, 643-SP03, and 643-SP04) were sorted out with the IMGA for further analysis because they had normal cerium retention (Figure 5-2) but low cesium retention (Figure 5-1 and Figure 5-3). Particle 643-SP01 was examined with x-ray tomography and determined to be missing the outer three TRISO layers (Figure 5-7). If this particle were missing these layers during deconsolidation and/or pre-burn leaching, then measurable kernel material would likely have been leached. Presumably, this particle was intact prior to the IMGA survey and fractured during one of the IMGA needle excursions. The relatively low cesium inventory was likely due to loss of cesium sequestered in the IPyC. In irradiated AGR particles, cesium has been generally observed throughout the IPyC and concentrated at the IPyC/SiC interface, and Compact 6-4-3 particles also exhibited this behavior, as discussed in Section 7.3.

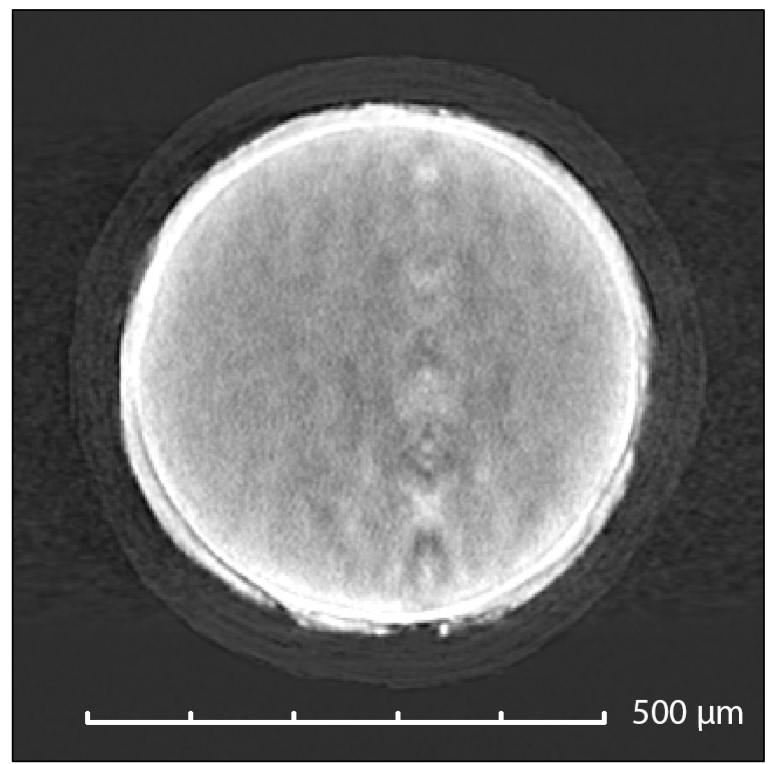

Figure 5-7. X-ray tomogram of Particle 643-SP01 showing that the outer three TRISO layers were missing. 
Figure 5-8 shows optical micrographs of polished sections of Particles 643-SP02, 643-SP03, and 643-SP04. Similar to Particle 643-SP01, these three particles were missing the outer layers as a result of the issues with the IMGA, which explains the low cesium inventories. Note that Particle 643-SP02, which was counted as a bare kernel, was missing almost all of its cesium inventory, showing that very little cesium was sequestered in the kernel of this TRISO particle heated to $1,800^{\circ} \mathrm{C}$.

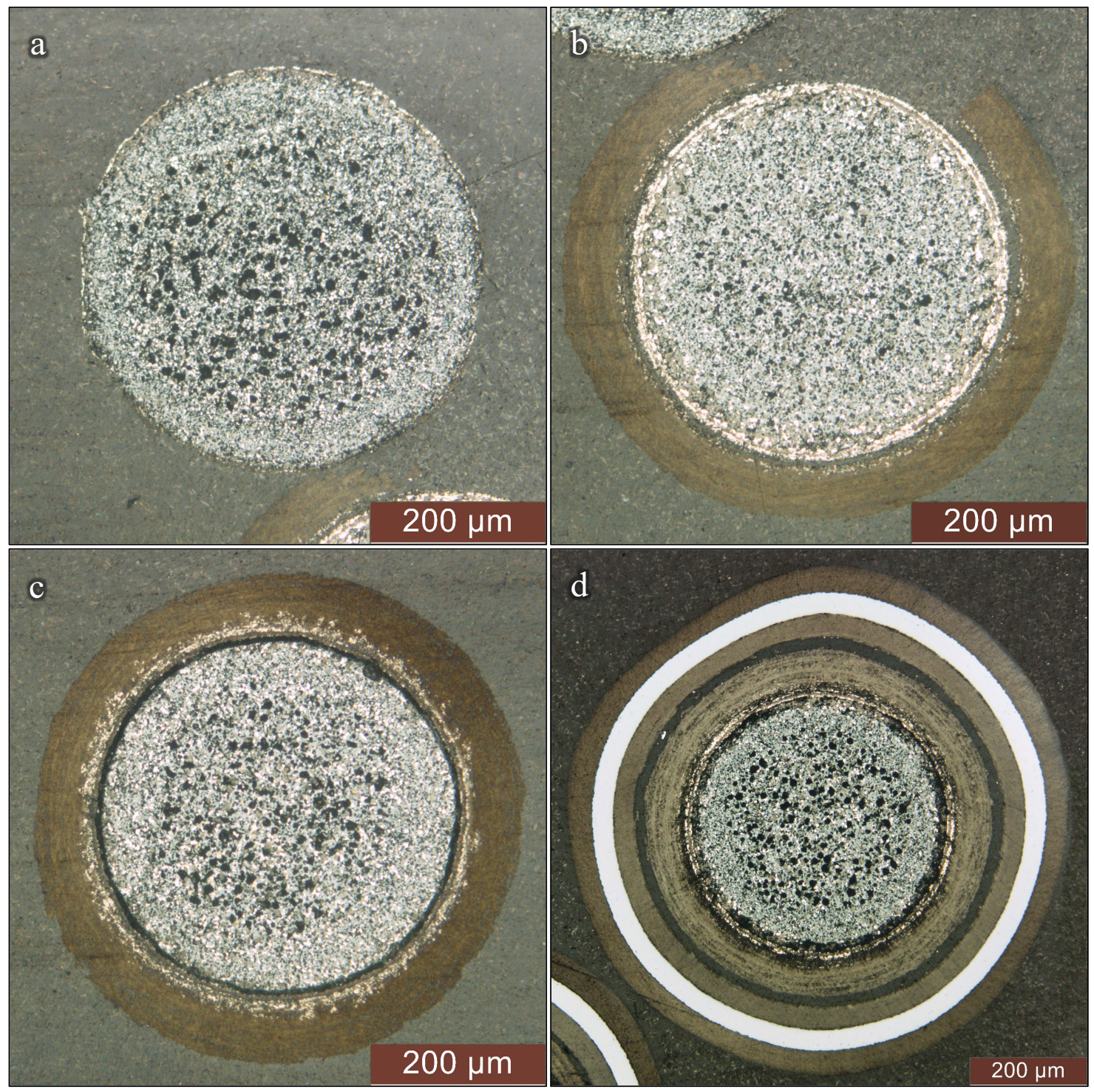

Figure 5-8. Micrographs of (a) Particle 643-SP02 with all TRISO layers missing, (b) Particle 643-SP03 with a piece of buffer and three outer TRISO layers missing, (c) Particle 643-SP04 with three outer TRISO layers missing, and (d) a typical Compact 6-4-3 particle for comparison.

\subsection{SIX-HOUR GAMMA COUNTING}

Gamma counting using a live time of $6 \mathrm{~h}$ was performed with the IMGA working in vial-handling mode so that individual particle identity could be retained. Table 5-1 shows the IMGA data for 45 randomly selected (RS) particles. The ${ }^{110 \mathrm{~m}} \mathrm{Ag}$ was almost unmeasurable because the ${ }^{110 \mathrm{~m}} \mathrm{Ag}$ activity at EOL for Compact 6-4-3 was relatively low, $26 \%$ of the average ${ }^{110 \mathrm{~m}} \mathrm{Ag}$ activity at EOL for compacts irradiated in AGR-2 Capsule 2 or Capsule 5, and there was less than 1\% of that inventory remaining after seven halflives of decay. After seven half-lives of decay, the $885 \mathrm{keV}$ gamma peak from ${ }^{110 \mathrm{~m}} \mathrm{Ag}$ in a Compact 6-4-3 particle with no silver release was at or below the background continuum. Five particles had measured ${ }^{110 \mathrm{~m}} \mathrm{Ag}$ activities that were barely resolvable above background. 
Table 5-1. Activity in 45 randomly selected particles

\begin{tabular}{|c|c|c|c|c|c|c|c|}
\hline Particle & ${ }^{106} \mathrm{Ru}$ & ${ }^{110 \mathrm{~m}} \mathrm{Ag}^{a}$ & ${ }^{125} \mathrm{Sb}$ & ${ }^{134} \mathrm{Cs}$ & ${ }^{137} \mathrm{Cs}$ & ${ }^{144} \mathrm{Ce}$ & ${ }^{154} \mathrm{Eu}$ \\
\hline 643-RS01 & $6.90 \mathrm{E}+6$ & $<1.87 \mathrm{E}+4$ & $1.48 \mathrm{E}+5$ & $1.69 \mathrm{E}+6$ & $3.05 \mathrm{E}+6$ & $3.42 \mathrm{E}+7$ & $6.39 \mathrm{E}+4$ \\
\hline 643-RS02 & $7.79 \mathrm{E}+6$ & $<1.91 \mathrm{E}+4$ & $1.61 \mathrm{E}+5$ & $1.62 \mathrm{E}+6$ & $3.09 \mathrm{E}+6$ & $3.62 \mathrm{E}+7$ & $6.26 \mathrm{E}+4$ \\
\hline 643-RS03 & $7.36 \mathrm{E}+6$ & $<1.98 \mathrm{E}+4$ & $1.59 \mathrm{E}+5$ & $1.99 \mathrm{E}+6$ & $3.26 \mathrm{E}+6$ & $3.33 \mathrm{E}+7$ & $7.61 \mathrm{E}+4$ \\
\hline 643-RS04 & $7.64 \mathrm{E}+6$ & $<1.91 \mathrm{E}+4$ & $1.64 \mathrm{E}+5$ & $1.76 \mathrm{E}+6$ & $3.25 \mathrm{E}+6$ & $3.72 \mathrm{E}+7$ & $6.55 \mathrm{E}+4$ \\
\hline 643-RS05 & $8.22 \mathrm{E}+6$ & $<2.07 \mathrm{E}+4$ & $1.78 \mathrm{E}+5$ & $2.14 \mathrm{E}+6$ & $3.57 \mathrm{E}+6$ & $3.84 \mathrm{E}+7$ & $8.20 \mathrm{E}+4$ \\
\hline 643-RS06 & $7.66 \mathrm{E}+6$ & $<1.91 \mathrm{E}+4$ & $1.67 \mathrm{E}+5$ & $2.06 \mathrm{E}+6$ & $3.43 \mathrm{E}+6$ & $3.56 \mathrm{E}+7$ & $7.76 \mathrm{E}+4$ \\
\hline 643-RS07 & $7.67 \mathrm{E}+6$ & $<2.06 \mathrm{E}+4$ & $1.70 \mathrm{E}+5$ & $1.99 \mathrm{E}+6$ & $3.47 \mathrm{E}+6$ & $3.69 \mathrm{E}+7$ & $7.52 \mathrm{E}+4$ \\
\hline 643-RS08 & $7.33 E+6$ & $<1.92 \mathrm{E}+4$ & $1.53 \mathrm{E}+5$ & $1.61 \mathrm{E}+6$ & $3.01 \mathrm{E}+6$ & $3.38 \mathrm{E}+7$ & $6.17 \mathrm{E}+4$ \\
\hline 643-RS09 & $7.38 \mathrm{E}+6$ & $1.70 \mathrm{E}+4$ & $1.54 \mathrm{E}+5$ & $1.70 \mathrm{E}+6$ & $3.13 \mathrm{E}+6$ & $3.57 \mathrm{E}+7$ & $6.38 \mathrm{E}+4$ \\
\hline 643-RS10 & $6.74 \mathrm{E}+6$ & $<1.96 \mathrm{E}+4$ & $1.46 \mathrm{E}+5$ & $1.74 \mathrm{E}+6$ & $2.98 \mathrm{E}+6$ & $3.21 \mathrm{E}+7$ & $6.72 \mathrm{E}+4$ \\
\hline 643-RS11 & $7.36 \mathrm{E}+6$ & $<1.96 \mathrm{E}+4$ & $1.58 \mathrm{E}+5$ & $1.77 \mathrm{E}+6$ & $3.24 \mathrm{E}+6$ & $3.59 \mathrm{E}+7$ & $6.71 \mathrm{E}+4$ \\
\hline 643-RS12 & $8.58 \mathrm{E}+6$ & $<2.07 \mathrm{E}+4$ & $1.77 \mathrm{E}+5$ & $1.99 \mathrm{E}+6$ & $3.54 \mathrm{E}+6$ & $4.05 \mathrm{E}+7$ & $7.39 \mathrm{E}+4$ \\
\hline 643-RS13 & $7.23 E+6$ & $<1.98 \mathrm{E}+4$ & $1.54 \mathrm{E}+5$ & $1.67 \mathrm{E}+6$ & $3.09 \mathrm{E}+6$ & $3.59 \mathrm{E}+7$ & $6.27 \mathrm{E}+4$ \\
\hline 643-RS14 & $7.68 \mathrm{E}+6$ & $1.83 \mathrm{E}+4$ & $1.66 \mathrm{E}+5$ & $1.83 \mathrm{E}+6$ & $3.30 \mathrm{E}+6$ & $3.66 \mathrm{E}+7$ & $6.95 \mathrm{E}+4$ \\
\hline 643-RS15 & $6.75 E+6$ & $1.78 \mathrm{E}+4$ & $1.48 \mathrm{E}+5$ & $1.60 \mathrm{E}+6$ & $2.93 \mathrm{E}+6$ & $3.42 \mathrm{E}+7$ & $6.02 \mathrm{E}+4$ \\
\hline 643-RS16 & $7.59 \mathrm{E}+6$ & $1.73 \mathrm{E}+4$ & $1.62 \mathrm{E}+5$ & $1.76 \mathrm{E}+6$ & $3.16 \mathrm{E}+6$ & $3.63 \mathrm{E}+7$ & $6.56 \mathrm{E}+4$ \\
\hline 643-RS17 & $7.25 \mathrm{E}+6$ & $<1.96 \mathrm{E}+4$ & $1.55 \mathrm{E}+5$ & $1.63 \mathrm{E}+6$ & $2.98 \mathrm{E}+6$ & $3.42 \mathrm{E}+7$ & $6.18 \mathrm{E}+4$ \\
\hline 643-RS18 & $7.43 E+6$ & $<1.98 \mathrm{E}+4$ & $1.63 \mathrm{E}+5$ & $1.77 \mathrm{E}+6$ & $3.24 \mathrm{E}+6$ & $3.64 \mathrm{E}+7$ & $6.66 \mathrm{E}+4$ \\
\hline 643-RS19 & $6.95 \mathrm{E}+6$ & $<2.00 \mathrm{E}+4$ & $1.47 \mathrm{E}+5$ & $1.76 \mathrm{E}+6$ & $3.07 \mathrm{E}+6$ & $3.48 \mathrm{E}+7$ & $6.61 \mathrm{E}+4$ \\
\hline 643-RS20 & $7.11 \mathrm{E}+6$ & $<2.05 \mathrm{E}+4$ & $1.56 \mathrm{E}+5$ & $1.90 \mathrm{E}+6$ & $3.23 \mathrm{E}+6$ & $3.50 \mathrm{E}+7$ & $7.05 \mathrm{E}+4$ \\
\hline 643-RS21 & $7.57 \mathrm{E}+6$ & $<1.99 \mathrm{E}+4$ & $1.59 \mathrm{E}+5$ & $1.78 \mathrm{E}+6$ & $3.24 \mathrm{E}+6$ & $3.77 \mathrm{E}+7$ & $6.73 \mathrm{E}+4$ \\
\hline 643-RS22 & $7.20 \mathrm{E}+6$ & $<1.99 \mathrm{E}+4$ & $1.58 \mathrm{E}+5$ & $1.85 \mathrm{E}+6$ & $3.27 \mathrm{E}+6$ & $3.59 \mathrm{E}+7$ & $6.92 \mathrm{E}+4$ \\
\hline 643-RS23 & $7.20 \mathrm{E}+6$ & $<1.93 \mathrm{E}+4$ & $1.56 \mathrm{E}+5$ & $1.64 \mathrm{E}+6$ & $3.06 \mathrm{E}+6$ & $3.56 \mathrm{E}+7$ & $6.21 \mathrm{E}+4$ \\
\hline 643-RS24 & $7.03 E+6$ & $<1.97 \mathrm{E}+4$ & $1.46 \mathrm{E}+5$ & $1.65 \mathrm{E}+6$ & $3.01 \mathrm{E}+6$ & $3.51 \mathrm{E}+7$ & $6.14 \mathrm{E}+4$ \\
\hline 643-RS25 & $7.31 \mathrm{E}+6$ & $1.96 \mathrm{E}+4$ & $1.54 \mathrm{E}+5$ & $1.76 \mathrm{E}+6$ & $3.08 \mathrm{E}+6$ & $3.51 \mathrm{E}+7$ & $6.67 \mathrm{E}+4$ \\
\hline 643-RS26 & $7.55 \mathrm{E}+6$ & $<1.95 \mathrm{E}+4$ & $1.52 \mathrm{E}+5$ & $1.56 \mathrm{E}+6$ & $2.93 \mathrm{E}+6$ & $3.39 \mathrm{E}+7$ & $5.93 \mathrm{E}+4$ \\
\hline 643-RS27 & $7.26 \mathrm{E}+6$ & $<1.33 \mathrm{E}+4$ & $1.51 \mathrm{E}+5$ & $1.70 \mathrm{E}+6$ & $3.06 \mathrm{E}+6$ & $3.61 \mathrm{E}+7$ & $6.40 \mathrm{E}+4$ \\
\hline 643-RS28 & $6.45 E+6$ & $<1.94 \mathrm{E}+4$ & $1.41 \mathrm{E}+5$ & $1.53 \mathrm{E}+6$ & $2.82 \mathrm{E}+6$ & $3.25 \mathrm{E}+7$ & $5.71 \mathrm{E}+4$ \\
\hline 643-RS29 & $6.83 E+6$ & $<1.90 \mathrm{E}+4$ & $1.43 \mathrm{E}+5$ & $1.51 \mathrm{E}+6$ & $2.84 \mathrm{E}+6$ & $3.30 \mathrm{E}+7$ & $5.74 \mathrm{E}+4$ \\
\hline 643-RS30 & $7.32 \mathrm{E}+6$ & $<2.00 \mathrm{E}+4$ & $1.54 \mathrm{E}+5$ & $1.76 \mathrm{E}+6$ & $3.16 \mathrm{E}+6$ & $3.56 \mathrm{E}+7$ & $6.66 \mathrm{E}+4$ \\
\hline 643-RS31 & $7.18 \mathrm{E}+6$ & $<1.88 \mathrm{E}+4$ & $1.45 \mathrm{E}+5$ & $1.41 \mathrm{E}+6$ & $2.73 \mathrm{E}+6$ & $3.35 \mathrm{E}+7$ & $5.35 \mathrm{E}+4$ \\
\hline 643-RS32 & $7.48 \mathrm{E}+6$ & $<2.04 \mathrm{E}+4$ & $1.58 \mathrm{E}+5$ & $1.77 \mathrm{E}+6$ & $3.27 \mathrm{E}+6$ & $3.67 \mathrm{E}+7$ & $6.58 \mathrm{E}+4$ \\
\hline 643-RS33 & $7.74 \mathrm{E}+6$ & $<2.02 \mathrm{E}+4$ & $1.63 \mathrm{E}+5$ & $1.82 \mathrm{E}+6$ & $3.29 \mathrm{E}+6$ & $3.67 \mathrm{E}+7$ & $6.79 \mathrm{E}+4$ \\
\hline 643-RS34 & $8.66 \mathrm{E}+6$ & $<2.15 \mathrm{E}+4$ & $1.82 \mathrm{E}+5$ & $2.03 \mathrm{E}+6$ & $3.55 \mathrm{E}+6$ & $4.02 \mathrm{E}+7$ & $7.53 \mathrm{E}+4$ \\
\hline 643-RS35 & $7.59 \mathrm{E}+6$ & $<2.07 \mathrm{E}+4$ & $1.66 \mathrm{E}+5$ & $1.87 \mathrm{E}+6$ & $3.40 \mathrm{E}+6$ & $3.82 \mathrm{E}+7$ & $6.91 \mathrm{E}+4$ \\
\hline 643-RS36 & $7.47 \mathrm{E}+6$ & $<1.93 \mathrm{E}+4$ & $1.62 \mathrm{E}+5$ & $1.78 \mathrm{E}+6$ & $3.26 \mathrm{E}+6$ & $3.76 \mathrm{E}+7$ & $6.63 \mathrm{E}+4$ \\
\hline 643-RS37 & $8.33 E+6$ & $<2.01 \mathrm{E}+4$ & $1.73 \mathrm{E}+5$ & $1.82 \mathrm{E}+6$ & $3.30 \mathrm{E}+6$ & $3.92 \mathrm{E}+7$ & $6.72 \mathrm{E}+4$ \\
\hline 643-RS38 & $7.32 \mathrm{E}+6$ & $<1.99 \mathrm{E}+4$ & $1.54 \mathrm{E}+5$ & $1.72 \mathrm{E}+6$ & $3.09 \mathrm{E}+6$ & $3.44 \mathrm{E}+7$ & $6.39 \mathrm{E}+4$ \\
\hline 643-RS39 & $8.11 \mathrm{E}+6$ & $<2.10 \mathrm{E}+4$ & $1.75 \mathrm{E}+5$ & $1.94 \mathrm{E}+6$ & $3.44 \mathrm{E}+6$ & $3.83 \mathrm{E}+7$ & $7.12 \mathrm{E}+4$ \\
\hline 643-RS40 & $8.40 \mathrm{E}+6$ & $<2.05 \mathrm{E}+4$ & $1.67 \mathrm{E}+5$ & $1.83 \mathrm{E}+6$ & $3.40 \mathrm{E}+6$ & $3.98 \mathrm{E}+7$ & $6.89 \mathrm{E}+4$ \\
\hline 643-RS41 & $7.41 \mathrm{E}+6$ & $<2.09 \mathrm{E}+4$ & $1.62 \mathrm{E}+5$ & $1.91 \mathrm{E}+6$ & $3.34 \mathrm{E}+6$ & $3.54 \mathrm{E}+7$ & $7.40 \mathrm{E}+4$ \\
\hline 643-RS42 & $6.89 \mathrm{E}+6$ & $<1.89 \mathrm{E}+4$ & $1.44 \mathrm{E}+5$ & $1.51 \mathrm{E}+6$ & $2.83 \mathrm{E}+6$ & $3.25 \mathrm{E}+7$ & $5.74 \mathrm{E}+4$ \\
\hline 643-RS43 & $6.55 \mathrm{E}+6$ & $<1.97 \mathrm{E}+4$ & $1.41 \mathrm{E}+5$ & $1.66 \mathrm{E}+6$ & $2.93 \mathrm{E}+6$ & $3.32 \mathrm{E}+7$ & $6.19 \mathrm{E}+4$ \\
\hline 643-RS44 & $7.01 \mathrm{E}+6$ & $<1.98 \mathrm{E}+4$ & $1.54 \mathrm{E}+5$ & $1.80 \mathrm{E}+6$ & $3.06 \mathrm{E}+6$ & $3.37 \mathrm{E}+7$ & $6.81 \mathrm{E}+4$ \\
\hline 643-RS45 & $7.48 \mathrm{E}+6$ & $<1.96 \mathrm{E}+4$ & $1.54 \mathrm{E}+5$ & $1.71 \mathrm{E}+6$ & $3.08 \mathrm{E}+6$ & $3.62 \mathrm{E}+7$ & $6.45 \mathrm{E}+4$ \\
\hline Maximum & $8.66 \mathrm{E}+6$ & $<2.15 \mathrm{E}+4$ & $1.82 \mathrm{E}+5$ & $2.14 \mathrm{E}+6$ & $3.57 \mathrm{E}+6$ & $4.05 \mathrm{E}+7$ & $8.20 \mathrm{E}+4$ \\
\hline Minimum & $6.45 \mathrm{E}+6$ & $<1.33 \mathrm{E}+4$ & $1.41 \mathrm{E}+5$ & $1.41 \mathrm{E}+6$ & $2.73 \mathrm{E}+6$ & $3.21 \mathrm{E}+7$ & $5.35 \mathrm{E}+4$ \\
\hline Mean & $7.42 \mathrm{E}+6$ & --- & $1.58 \mathrm{E}+5$ & $1.76 \mathrm{E}+6$ & $3.17 \mathrm{E}+6$ & $3.58 \mathrm{E}+7$ & $6.63 \mathrm{E}+4$ \\
\hline Std. Dev. & $6.7 \%$ & --- & $6.3 \%$ & $8.8 \%$ & $6.5 \%$ & $5.8 \%$ & $8.8 \%$ \\
\hline
\end{tabular}

Note: Values reported in Bq decay-corrected to one day after EOL.

${ }^{a}$ Less-than values indicate that the ${ }^{110 \mathrm{~m}} \mathrm{Ag}$ activity was below the detection limit. Summary values for ${ }^{110 \mathrm{~m}} \mathrm{Ag}$ are not relevant. 
Table 5-2 shows how the measured activities in the randomly selected particles compare to the calculated values. The table does not include ${ }^{110 \mathrm{~m}} \mathrm{Ag}$ because of the low signal-to-background issue. The significant bias between the measured and calculated activities for ${ }^{125} \mathrm{Sb}$ and ${ }^{154} \mathrm{Eu}$ does not indicate that these isotopes were released. These biases were due to a known offset error in the calculated values, and they are consistent with the biases observed in the AGR-1 calculations when compared to results obtained from gamma scanning the whole compacts with the Idaho National Laboratory (INL) Precision Gamma Scanner (PGS) (Harp et al. 2014). The mean ratio of measured-to-calculated activity for ${ }^{134} \mathrm{Cs}$ in Compact 6-4-3 particles appears to be slightly low, but error in the calculated value is likely the primary contributor to this bias, as well. A similar bias was observed in the ratio of measured to calculated activity for ${ }^{134} \mathrm{Cs}$ in Compact 6-3-3 particles (0.86).

Table 5-2. Summary of results from 6-hour IMGA analysis of Compact 6-4-3 particles

\begin{tabular}{|c|c|c|c|c|c|c|c|}
\hline \multirow[t]{2}{*}{ Isotope } & \multirow{2}{*}{$\begin{array}{c}\text { Calculated } \\
\text { activity }^{a} \\
\text { (Bq/particle) }\end{array}$} & \multicolumn{2}{|c|}{$\begin{array}{l}\text { Measured activity }{ }^{b} \\
\text { (Bq/particle) }\end{array}$} & \multicolumn{2}{|c|}{$\begin{array}{l}\text { Ratio of measured vs. } \\
\text { calculated activity }\end{array}$} & \multicolumn{2}{|c|}{$\begin{array}{l}\text { Measured-to-calculated ratio ir } \\
\text { AGR-1 compact activity }{ }^{d}\end{array}$} \\
\hline & & mean & std. dev. & mean & std. dev. & mean & std. dev. \\
\hline${ }^{106} \mathrm{Ru}$ & $7.08 \mathrm{E}+6$ & $7.42 \mathrm{E}+6$ & $6.7 \%$ & 1.05 & 0.07 & 0.96 & 0.04 \\
\hline${ }^{125} \mathrm{Sb}$ & $2.15 \mathrm{E}+5$ & $1.58 \mathrm{E}+5$ & $6.3 \%$ & 0.73 & 0.05 & 0.70 & 0.04 \\
\hline${ }^{134} \mathrm{Cs}$ & $1.95 \mathrm{E}+6$ & $1.76 \mathrm{E}+6$ & $8.8 \%$ & 0.90 & 0.08 & 0.97 & 0.05 \\
\hline${ }^{137} \mathrm{Cs}$ & $3.22 \mathrm{E}+6$ & $3.17 \mathrm{E}+6$ & $6.5 \%$ & 0.98 & 0.06 & 0.99 & 0.03 \\
\hline${ }^{144} \mathrm{Ce}$ & $3.63 \mathrm{E}+7$ & $3.58 \mathrm{E}+7$ & $5.8 \%$ & 0.98 & 0.06 & 1.00 & 0.04 \\
\hline${ }^{154} \mathrm{Eu}$ & $8.04 \mathrm{E}+4$ & $6.63 \mathrm{E}+4$ & $8.8 \%$ & 0.82 & 0.07 & 0.83 & 0.04 \\
\hline
\end{tabular}

${ }^{a}$ Calculated activity for one day after EOL.

${ }^{b}$ Measured activity decay-corrected to one day after EOL.

${ }^{c}$ Not the same as $\mathrm{M} / \mathrm{C}$, which is also adjusted for variation in fissionable material and burnup.

${ }^{d}$ Summary results from gamma scanning of whole AGR-1 compacts (Demkowicz et al. 2015, Table 14).

Table 5-3 shows the measured activities for the special particles sorted out by the IMGA. For some of the isotopes, the $\mathrm{M} / \mathrm{C}$ values are also shown, adjusted for variation in initial fissile content and burnup using the normalized ${ }^{144} \mathrm{Ce}$, as described in Section 2.2. As shown in Figure 5-8, Particle 643-SP02 was a bare kernel when it was gamma counted. The low cesium inventory suggests that most of the cesium generated during irradiation must have been sequestered in the buffer and IPyC. The ${ }^{154} \mathrm{Eu}$ inventory was also significantly below average in the bare kernel, indicating that europium had also diffused out into the surrounding carbon layers. The other three special particles that were gamma counted as buffer-coated kernels had higher europium inventories but were still below average. This suggests that significant europium was sequestered in the buffer and IPyC.

Table 5-3. Activity in special particles

\begin{tabular}{|c|c|c|c|c|c|c|c|}
\hline Particle & ${ }^{106} \mathrm{Ru}$ & ${ }^{110 m} \mathrm{Ag}^{a}$ & ${ }^{125} \mathrm{Sb}$ & ${ }^{134} \mathrm{Cs}$ & ${ }^{137} \mathrm{Cs}$ & ${ }^{144} \mathrm{Ce}$ & ${ }^{154} \mathbf{E u}$ \\
\hline 643-SP01 & $\begin{array}{c}8.19 \mathrm{E}+6 \\
(1.02)\end{array}$ & $<1.86 \mathrm{E}+4$ & $\begin{array}{c}1.60 \mathrm{E}+5 \\
(0.94)\end{array}$ & $\begin{array}{c}1.33 \mathrm{E}+6 \\
(0.70)\end{array}$ & $\begin{array}{c}2.37 \mathrm{E}+6 \\
(0.69)\end{array}$ & $3.87 \mathrm{E}+7$ & $\begin{array}{c}5.43 \mathrm{E}+4 \\
(0.76)\end{array}$ \\
\hline 643-SP02 & $\begin{array}{c}6.72 \mathrm{E}+6 \\
(0.95)\end{array}$ & $<1.44 \mathrm{E}+4$ & $\begin{array}{c}1.19 \mathrm{E}+5 \\
(0.79)\end{array}$ & $\begin{array}{c}7.54 \mathrm{E}+4 \\
(0.04)\end{array}$ & $\begin{array}{c}1.65 \mathrm{E}+5 \\
(0.05)\end{array}$ & $3.41 \mathrm{E}+7$ & $\begin{array}{c}3.04 \mathrm{E}+4 \\
(0.48)\end{array}$ \\
\hline 643-SP03 & $\begin{array}{c}6.57 \mathrm{E}+6 \\
(0.95)\end{array}$ & $<1.71 \mathrm{E}+4$ & $\begin{array}{c}1.28 \mathrm{E}+5 \\
(0.88)\end{array}$ & $\begin{array}{c}1.04 \mathrm{E}+6 \\
(0.64)\end{array}$ & $\begin{array}{c}1.85 \mathrm{E}+6 \\
(0.63)\end{array}$ & $3.32 \mathrm{E}+7$ & $\begin{array}{c}4.54 \mathrm{E}+4 \\
(0.74)\end{array}$ \\
\hline 643-SP04 & $\begin{array}{c}8.97 \mathrm{E}+6 \\
(1.05)\end{array}$ & $<1.91 \mathrm{E}+4$ & $\begin{array}{c}1.76 \mathrm{E}+5 \\
(0.97)\end{array}$ & $\begin{array}{c}1.61 \mathrm{E}+6 \\
(0.80)\end{array}$ & $\begin{array}{c}2.71 \mathrm{E}+6 \\
(0.75)\end{array}$ & $4.11 \mathrm{E}+7$ & $\begin{array}{c}6.39 \mathrm{E}+4 \\
(0.84)\end{array}$ \\
\hline
\end{tabular}

Note: Activities are reported in $\mathrm{Bq}$ decay-corrected to one day after $\mathrm{EOL}$ and $\mathrm{M} / \mathrm{C}$ adjusted by normalized ${ }^{144} \mathrm{Ce}$ (in parentheses).

${ }^{a}$ Less-than values indicate that the ${ }^{110 \mathrm{~m}} \mathrm{Ag}$ activity was below the detection limit. 


\section{X-RAY COMPUTED TOMOGRAPHY}

Two representative average particles were selected for x-ray computed tomography (XCT) from the randomly selected particles listed in Table 5-1. To select representative average particles, the M/A values were calculated as described in Section 2.2 to remove the calculated inventory bias discussed in Section 5.2 (Table 5-2) that resulted in a bias in the M/C values. This made it easier to survey the results with respect to the average. Table 6-1 shows the $\mathrm{M} / \mathrm{C}$ and $\mathrm{M} / \mathrm{A}$ values for the two particles selected for XCT.

\section{Table 6-1. Particles selected for x-ray tomography}

\begin{tabular}{|c|c|c|c|c|c|c|c|}
\hline \multicolumn{8}{|c|}{ Measured vs. calculated inventory $(\mathrm{M} / \mathrm{C})^{a}$} \\
\hline Particle & ${ }^{106} \mathrm{Ru}$ & ${ }^{110 \mathrm{~m}} \mathrm{Ag}^{c}$ & ${ }^{125} \mathrm{Sb}$ & ${ }^{134} \mathrm{Cs}$ & ${ }^{137} \mathrm{Cs}$ & ${ }^{144} \mathrm{Ce}$ & ${ }^{154} \mathbf{E u}$ \\
\hline 643-RS33 & 1.05 & $<1.31$ & 0.73 & 0.90 & 0.99 & 0.97 & .81 \\
\hline 643-RS38 & 1.06 & $<1.37$ & 0.73 & 0.90 & 0.99 & 0.97 & .82 \\
\hline \multicolumn{8}{|c|}{ Measured vs. average inventory $(\mathrm{M} / \mathrm{A})^{b}$} \\
\hline Particle & ${ }^{106} \mathbf{R u}$ & ${ }^{110 m} \mathrm{Ag}^{c}$ & ${ }^{125} \mathrm{Sb}$ & ${ }^{134} \mathrm{Cs}$ & ${ }^{137} \mathrm{Cs}$ & ${ }^{144} \mathrm{Ce}$ & ${ }^{154} \mathbf{E u}$ \\
\hline 643-RS33 & 1.00 & $<1.08$ & 0.99 & 1.00 & 1.01 & 0.99 & 0.98 \\
\hline 643-RS38 & 1.01 & $<1.13$ & 1.00 & 1.00 & 1.01 & 0.99 & 0.99 \\
\hline \multicolumn{8}{|c|}{$\begin{array}{l}a \mathrm{M} / \mathrm{C} \text { values were adjusted for fissile material and burnup using the normalized }{ }^{137} \mathrm{Cs} \text { activity, except for }{ }^{137} \mathrm{Cs} \text {, which used } \\
\text { the normalized }{ }^{144} \mathrm{Ce} \text { activity. } \\
\text { th } \mathrm{M} / \mathrm{A} \text { values were adjusted for fissile material and burnup using the normalized }{ }^{137} \mathrm{Cs} \text { activity, except for }{ }^{137} \mathrm{Cs} \text {, which used } \\
\text { the normalized }{ }^{144} \mathrm{Ce} \text { activity. }\end{array}$} \\
\hline \multicolumn{8}{|c|}{$\begin{array}{l}\text { Figure 6-1 shows two orthogonal tomograms through the center of Particle } 643-\mathrm{RS} 33 \text {. This particle } \\
\text { exhibited the typical buffer densification and separation from the buffer/IPyC interface, with one region } \\
\text { still attached due to the reduction in stress once the remainder of the layer was free. An apparent } \\
\text { separation was also observed between the OPyC and } \mathrm{SiC} \text {, which is visible in the figure at the bottom of } \\
\text { the particle. Figure } 6-2 \text { shows two orthogonal tomograms through the center of Particle } 643-\mathrm{RS} 38 \text {. This } \\
\text { particle had the same buffer behavior as Particle } 643-\mathrm{RS} 33 \text {. The OPyC in Particle } 643-\mathrm{RS} 38 \text { has fractured } \\
\text { and expanded away from the SiC, presumably due to residual stress in the OPyC. The OPyC fracture } \\
\text { likely occurred during IMGA particle handling as a result of the needle control problems already } \\
\text { discussed. }\end{array}$} \\
\hline
\end{tabular}



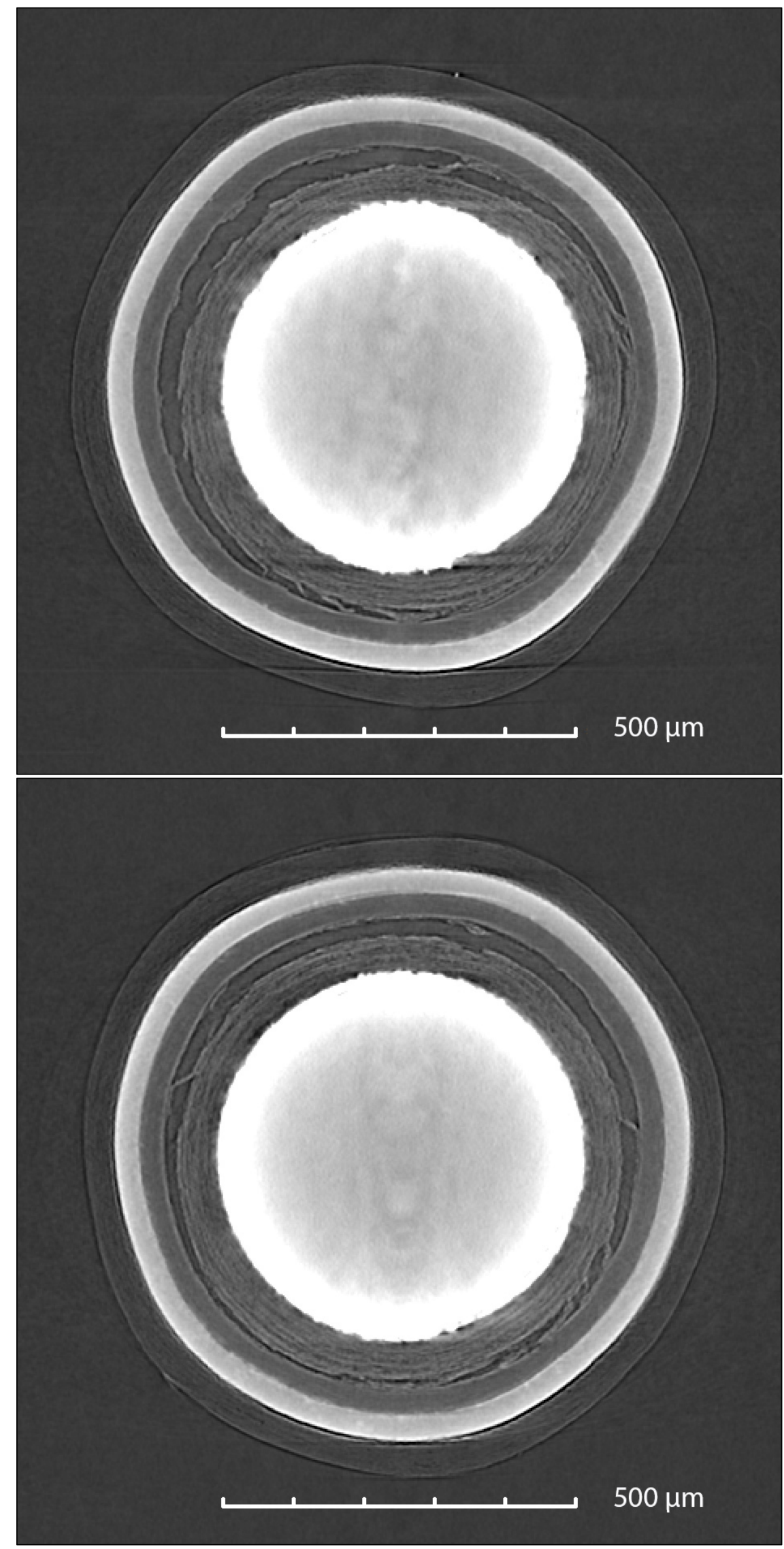

Figure 6-1. Orthogonal tomograms through the center of Particle 643-RS33. 

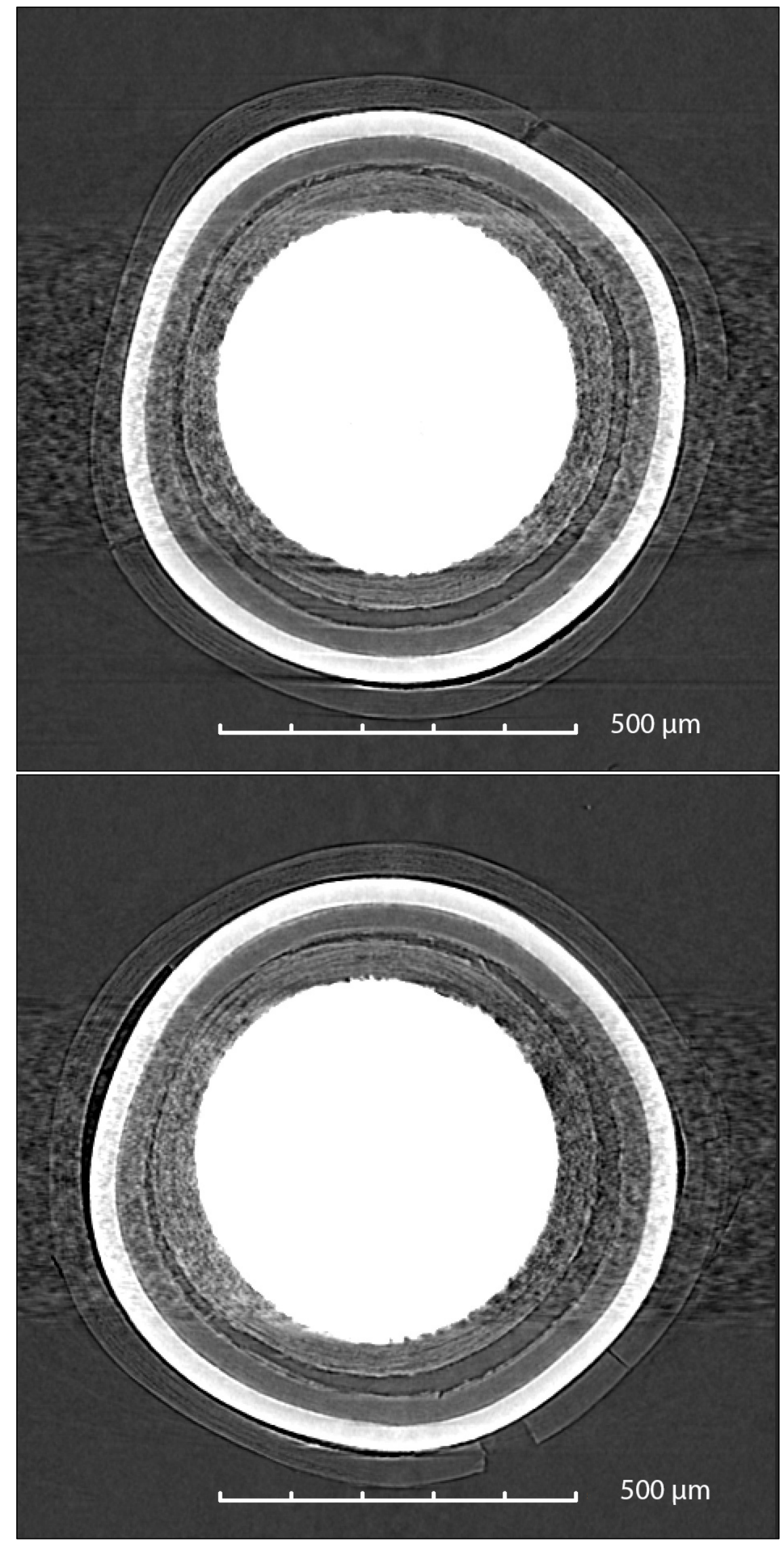

Figure 6-2. Orthogonal tomograms through the center of Particle 643-RS38. 


\section{MATERIALOGRAPHY}

Table 7-1 shows particles selected for materialography from the 45 randomly selected particles listed in Table 5-1. As described in Section 2.2, the M/A values were calculated and used to select particles with average isotopic inventories. Only one particle had measurable ${ }^{110 \mathrm{~m}} \mathrm{Ag}$ inventory, but the detection limits determined from the background continuum in the gamma spectra were too high to make a comparison with regard to differences in actual silver retention.

Table 7-1. Particles selected for materialography

Measured vs. calculated inventory $(\mathrm{M} / \mathrm{C})^{a}$

\begin{tabular}{cccccccc}
\hline Particle & ${ }^{{ }^{10}} \mathbf{R u}$ & ${ }^{{ }^{110} \mathbf{m}} \mathbf{A g}{ }^{\boldsymbol{c}}$ & ${ }^{{ }^{125}} \mathbf{S b}$ & ${ }^{134} \mathbf{C s}$ & ${ }^{{ }^{137}} \mathbf{C s}$ & ${ }^{{ }^{144}} \mathbf{C e}$ & ${ }^{{ }^{154}} \mathbf{E u}$ \\
\hline $643-R S 12$ & 1.08 & $<1.25$ & 0.73 & 0.91 & 0.97 & 1.00 & 0.82 \\
$643-R S 15$ & 1.03 & 1.29 & 0.74 & 0.88 & 0.95 & 1.02 & 0.81 \\
$643-R S 27$ & 1.06 & $<0.93$ & 0.73 & 0.90 & 0.94 & 1.03 & 0.82 \\
$643-R S 43$ & 1.00 & $<1.43$ & 0.71 & 0.92 & 0.98 & 0.99 & 0.83 \\
\hline
\end{tabular}

Measured vs. average inventory (M/A) ${ }^{b}$

\begin{tabular}{|c|c|c|c|c|c|c|c|}
\hline Particle & ${ }^{106} \mathrm{Ru}$ & ${ }^{110 m} \mathrm{Ag}^{c}$ & ${ }^{125} \mathrm{Sb}$ & ${ }^{134} \mathrm{Cs}$ & ${ }^{137} \mathrm{Cs}$ & ${ }^{144} \mathrm{Ce}$ & ${ }^{154} \mathbf{E u}$ \\
\hline 643-RS12 & 1.03 & $<1.03$ & 1.00 & 1.01 & 0.99 & 1.01 & 1.00 \\
\hline 643-RS15 & 0.98 & 1.07 & 1.01 & 0.98 & 0.97 & 1.03 & 0.98 \\
\hline 643-RS27 & 1.01 & $<0.77$ & 0.99 & 1.00 & 0.96 & 1.04 & 1.00 \\
\hline 643-RS43 & 0.95 & $<1.18$ & 0.97 & 1.02 & 1.00 & 1.00 & 1.01 \\
\hline
\end{tabular}

${ }^{a} \mathrm{M} / \mathrm{C}$ values were adjusted for fissile material and burnup using the normalized ${ }^{137} \mathrm{Cs}$ activity, except for ${ }^{137} \mathrm{Cs}$, which used the normalized ${ }^{144} \mathrm{Ce}$ activity.

${ }^{b} \mathrm{M} / \mathrm{A}$ values were adjusted for fissile material and burnup using the normalized ${ }^{137} \mathrm{Cs}$ activity, except for ${ }^{137} \mathrm{Cs}$, which used the normalized ${ }^{144} \mathrm{Ce}$ activity.

${ }^{c}$ Less-than values indicate that the ${ }^{110 \mathrm{~m}} \mathrm{Ag}$ activity was below the detection limit.

\subsection{OPTICAL IMAGING}

Particles were mounted and polished to near midplane using the methods and equipment developed for AGR-1 PIE (Hunn et al. 2013), and polished cross sections were imaged with a Leica DMI5000 optical microscope. These particles were further examined by SEM with EDS analysis of the distribution of fission products and actinides in the IPyC and SiC, as discussed in Sections 7.2 and 7.3. Kernel friability during the sample preparation resulted in some deep surface scratches from kernel debris, which are evident in the optical micrographs, and degradation of the kernel buffer interface, which precluded detailed examination of that structure. 


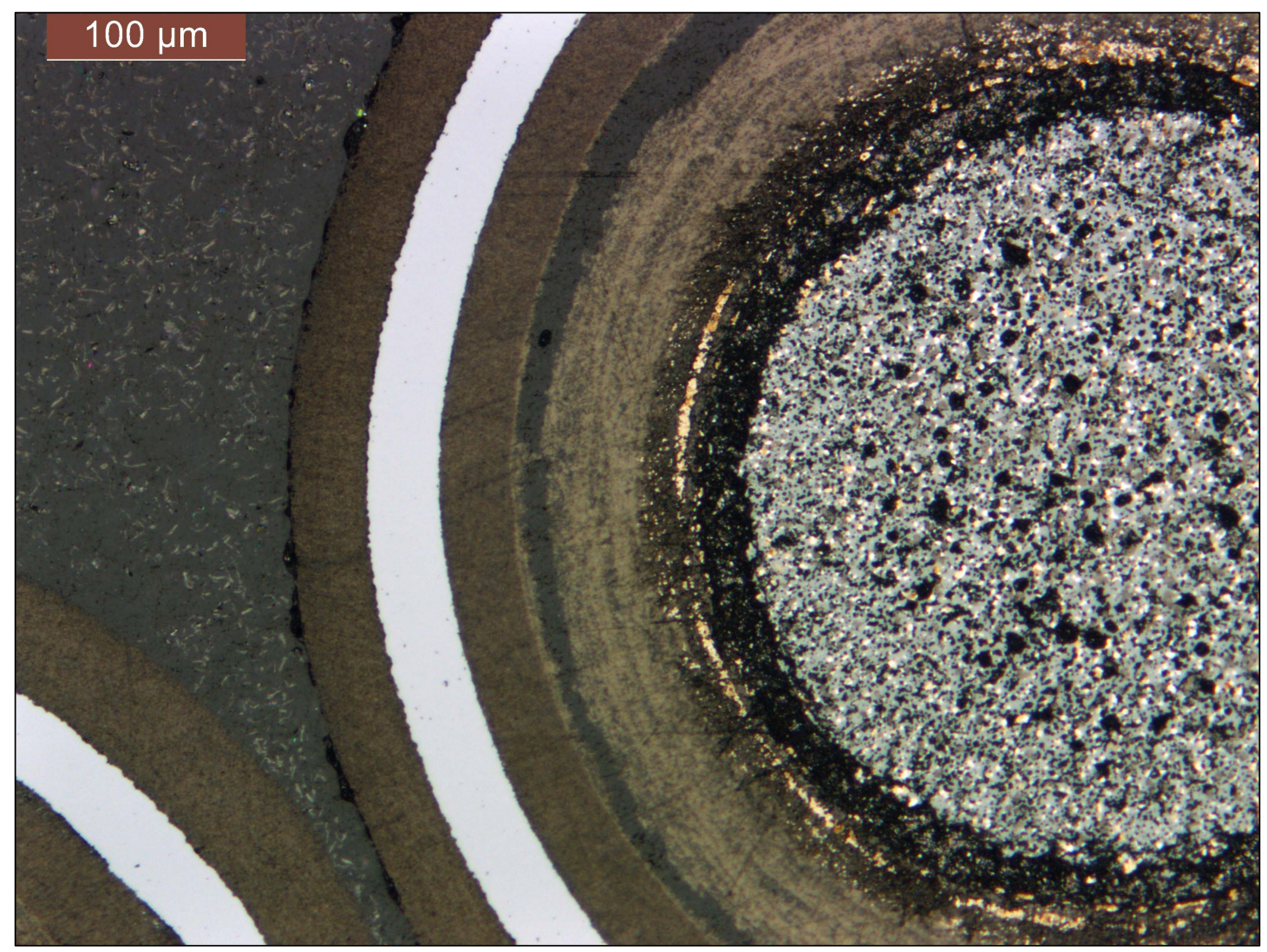

Figure 7-1. Optical micrograph of Particle 642-RS12 near midplane.

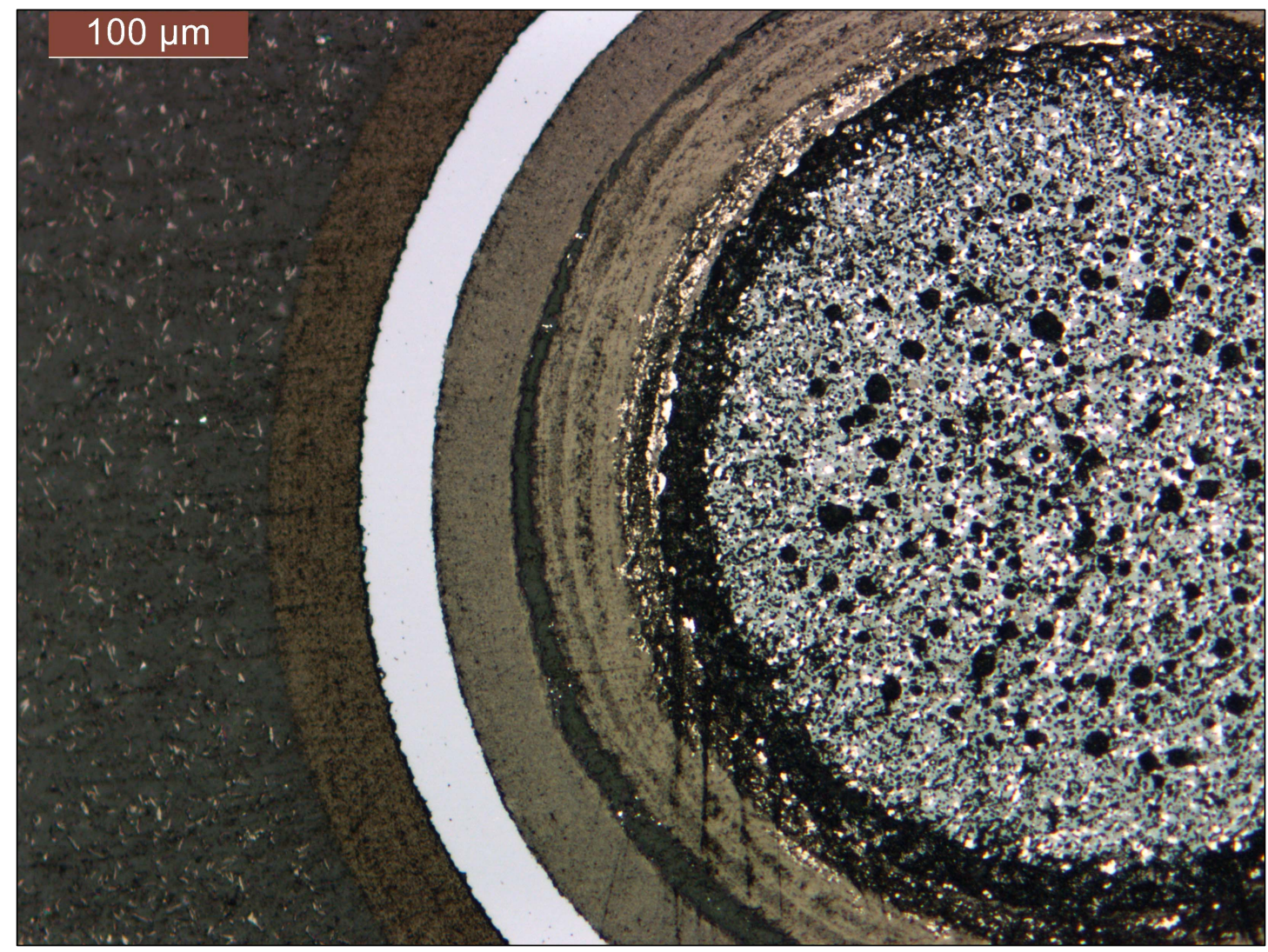

Figure 7-2. Optical micrograph of Particle 642-RS15 near midplane. 


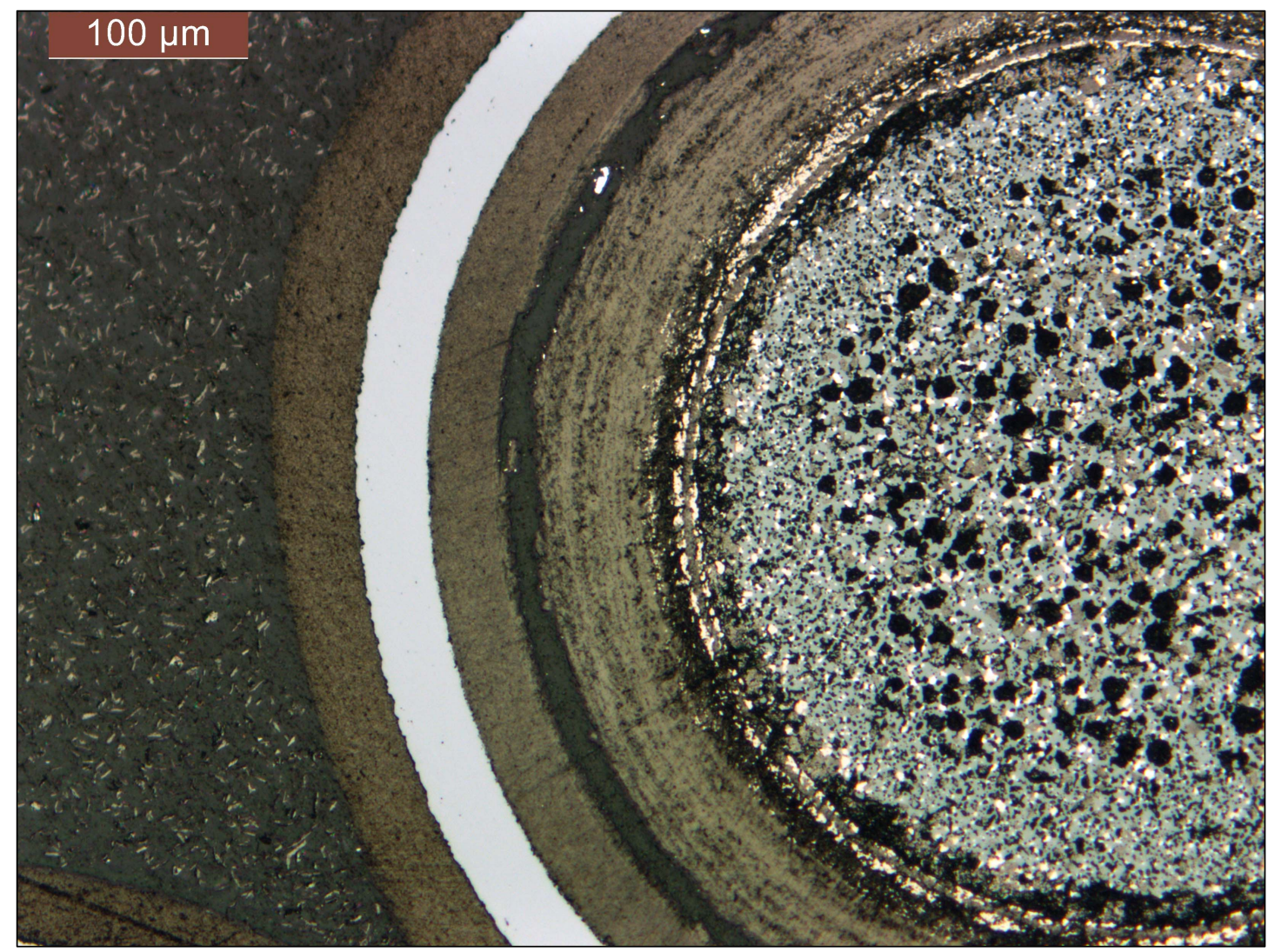

Figure 7-3. Optical micrograph of Particle 642-RS27 near midplane.

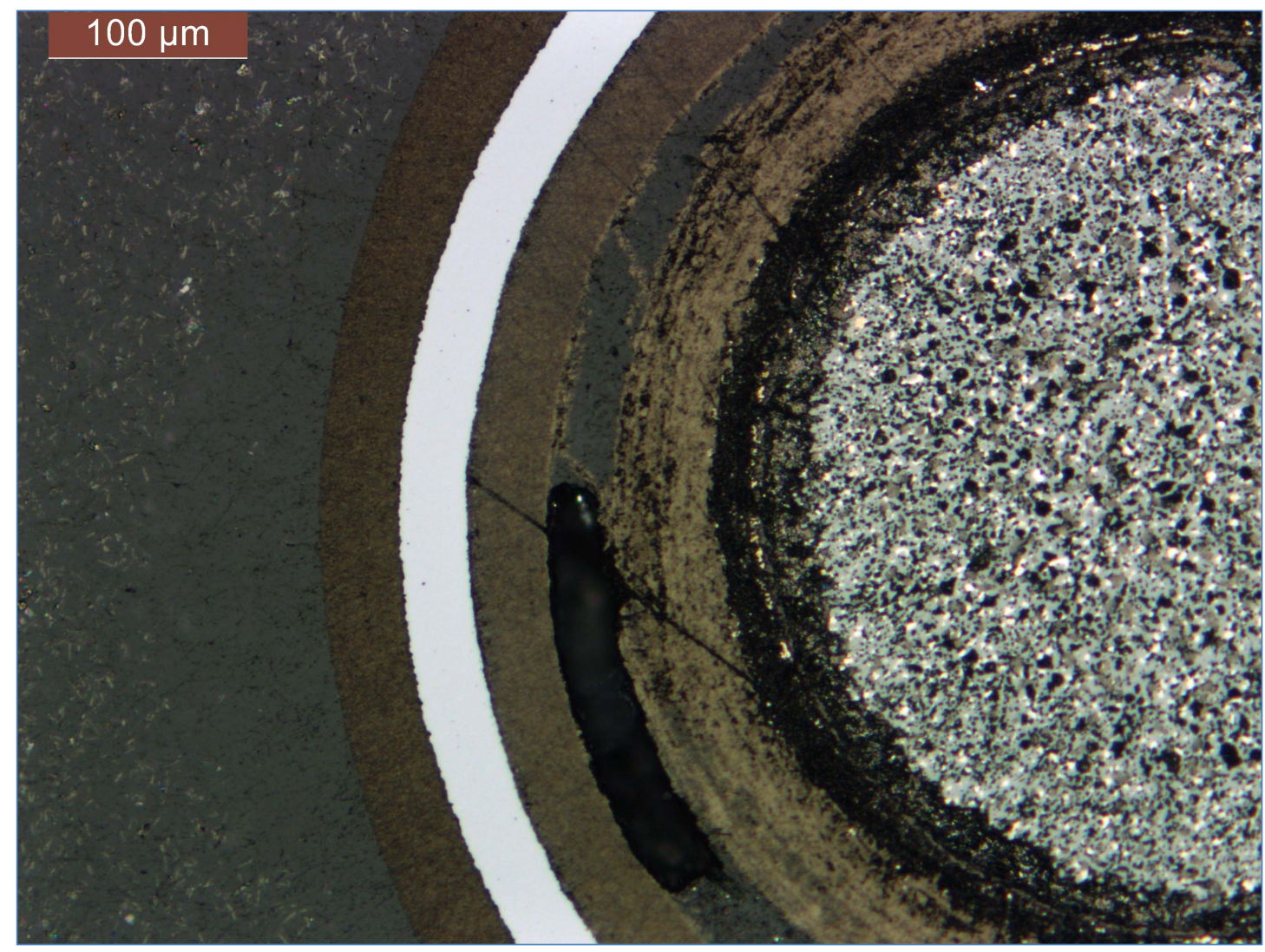

Figure 7-4. Optical micrograph of Particle 642-RS43 near midplane. 


\subsection{SEM IMAGING}

The particles subjected to materialography and SEM analysis are listed in Table 7-1, along with their associated fission product inventories determined with the IMGA. Section 2.3 provides a summary of the SEM and EDS analysis methods. Qualitative differences have previously been observed regarding high-Z fission product and actinide interaction with the TRISO layers of particles, with varying ${ }^{110 \mathrm{~m}} \mathrm{Ag}$ retention. As such, particles with bounding silver retention (high vs. low ${ }^{110 \mathrm{~m}} \mathrm{Ag} \mathrm{M} / \mathrm{C}$ ) are usually targeted for analysis when performing destructive PIE. This approach has provided insight into the fission product and actinide distribution in particles that presumably experienced different reactor temperatures. In general, particles with low retention have shown an increase in fission product and actinide pileup and penetration into the $\mathrm{SiC}$ layer as compared to particles with high retention (Gerczak et al. 2018; Demkowicz et al. 2015). However, in the SEM analysis of the particles from Compact 6-4-3, fission product and actinide distribution in Compact 6-4-3 could not be correlated to remaining silver inventory, because the IMGA data were insufficient for rigorously determining which particles had low silver retention due to the high

${ }^{110 \mathrm{~m}} \mathrm{Ag}$ detection limits. Nevertheless, some variations in the distribution of fission products and actinides were observed, as discussed below.

Figure 7-5 through Figure 7-12 are BEC micrographs that provide an overview of the TRISO layers revealed by polishing each particle to near midplane. All particles had bright spots resulting from clustered elements with an atomic number higher than the layer material. These high-Z features were catalogued based on the four general regions in which they were located. High- $Z$ features on the $\mathrm{IPyC} / \mathrm{SiC}$ boundary, which are delineated by the abrupt contrast between the IPyC and $\mathrm{SiC}$ regions, were catalogued as high-Z boundary features (Figure 7-14). Features embedded in the $\mathrm{SiC}$ layer but not in apparent contact with the IPyC/SiC boundary were catalogued as high-Z SiC features (Figure 7-5). Some of these features were large enough and close enough to the polished surface to be observed in SEI micrographs. Figure 7-13 and Figure 7-14 are examples of BEC/SEI micrographs of the same region that were used to differentiate between bright spots from embedded features and those caused by surface debris. The embedded nature of this type of feature has been confirmed by analysis with transmission electron microscopy (van Rooyen et al. 2014). Features in the IPyC that were less than $10 \mu \mathrm{m}$ from the $\mathrm{IPyC} / \mathrm{SiC}$ boundary were catalogued as high-Z interface features. The IPyC/SiC interface region is a band in the IPyC adjacent to the IPyC/SiC boundary formed by $\mathrm{SiC}$ penetration into the open surface porosity of the IPyC during deposition. The $10 \mu \mathrm{m}$ demarcation line was chosen as an estimate of the maximum depth of SiC infiltration into this interface region. High-Z interface features appeared in many locations around the circumference of each particle and were often concentrated in radial bands that were clearly separated from the IPyC/SiC boundary by a few microns of IPyC with lower feature concentration. These concentrated bands in the $\mathrm{IPyC} / \mathrm{SiC}$ interface region were likely related to fission product and actinide interaction with the SiC fingers penetrating into the IPyC. High-Z features in the IPyC that were more than $10 \mu \mathrm{m}$ away from the IPyC/SiC boundary were catalogued as high-Z IPyC features (e.g., Figure 7-11). There was a much lower overall population density of high-Z IPyC features compared to high-Z interface features. The high-Z IPyC features were often located along discreet radial bands in the IPyC layer, such as the band labeled in Figure 7-9. This may be related to the banded pore structure often observed in the pyrolytic carbon layers; this structure is formed as particles circulate between higher and lower deposition rate zones in the fluidized bed of the coating furnace.

Other observed features included dark spots indicating either SiC pull-out or low-density regions in the $\mathrm{SiC}$ that could be associated with carbon-rich zones left behind by silicide formation (Figure 7-13). In addition, all particles had small, discrete regions along the IPyC/SiC boundary that appeared to be localized $\mathrm{SiC}$ degradation, such as those shown in Figure 7-15. 


\section{PARTICLE 643-RS12 OVERVIEW}

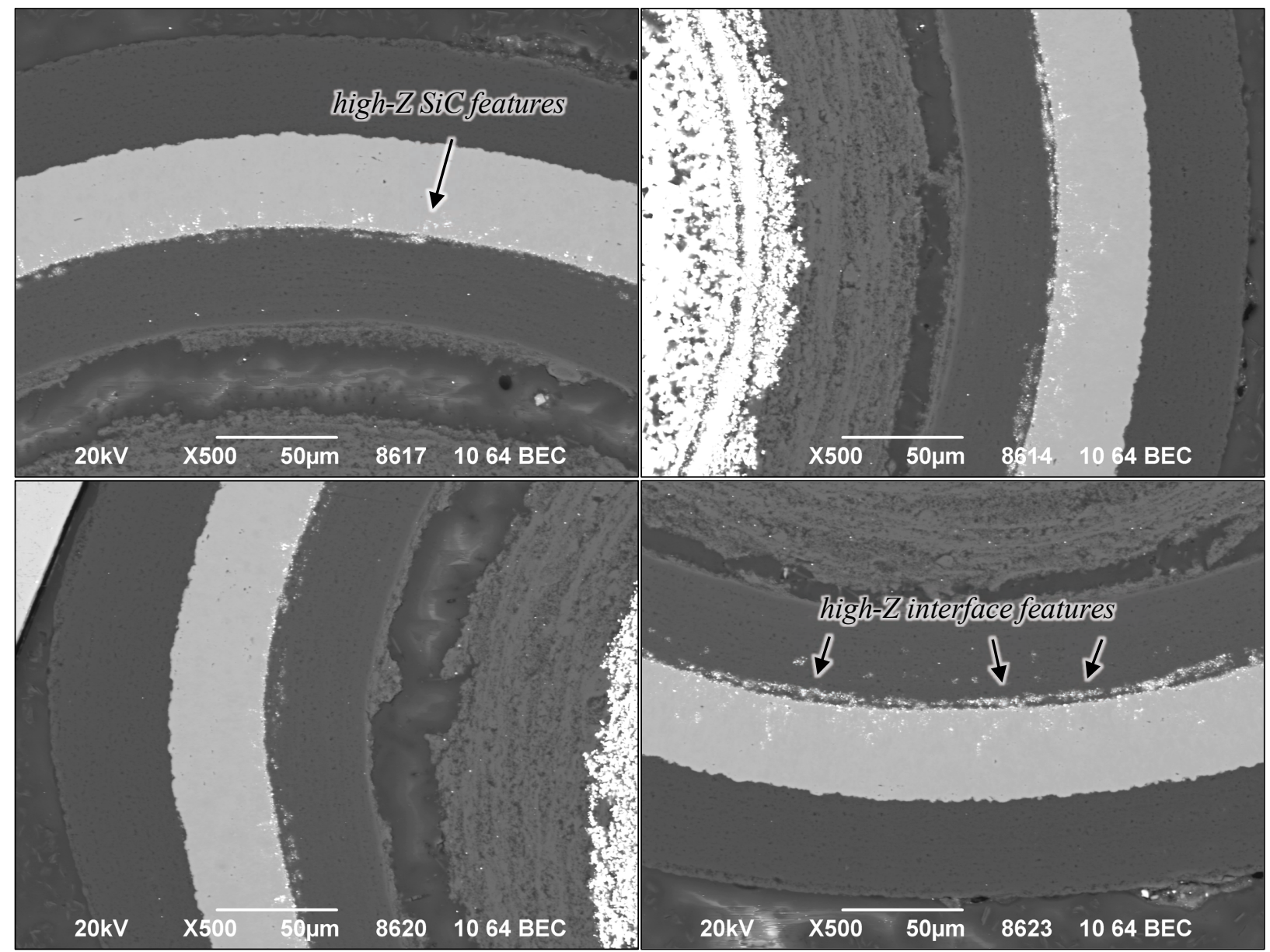

Figure 7-5. Four 500 $\times$ SEM magnification BEC images of Particle $643-R S 12$ with ${ }^{110 \mathrm{~m}} \mathrm{Ag} \mathrm{M} / \mathrm{C}<1.25$.

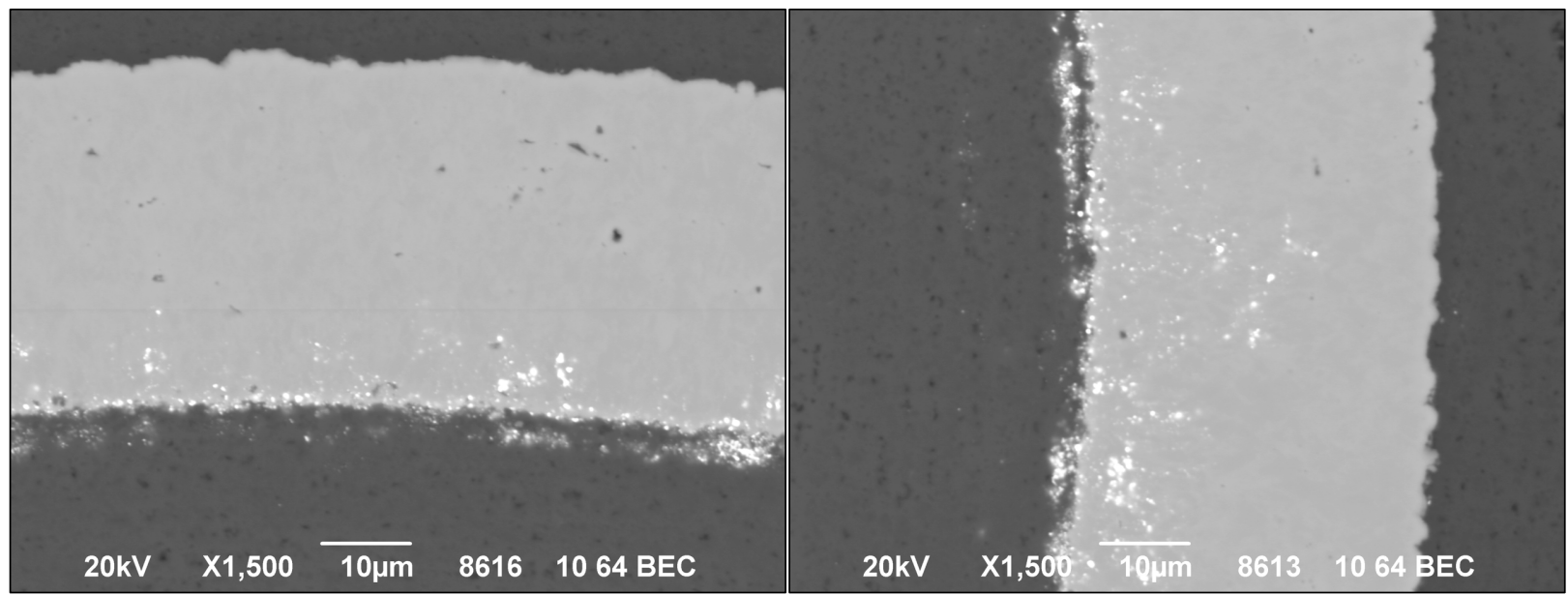

Figure 7-6. Two 1500 $\times$ SEM magnification BEC images of Particle $643-\mathrm{RS} 12$ with ${ }^{110 \mathrm{~m}} \mathrm{Ag} \mathrm{M} / \mathrm{C}<1.25$. 


\section{PARTICLE 643-RS15 OVERVIEW}

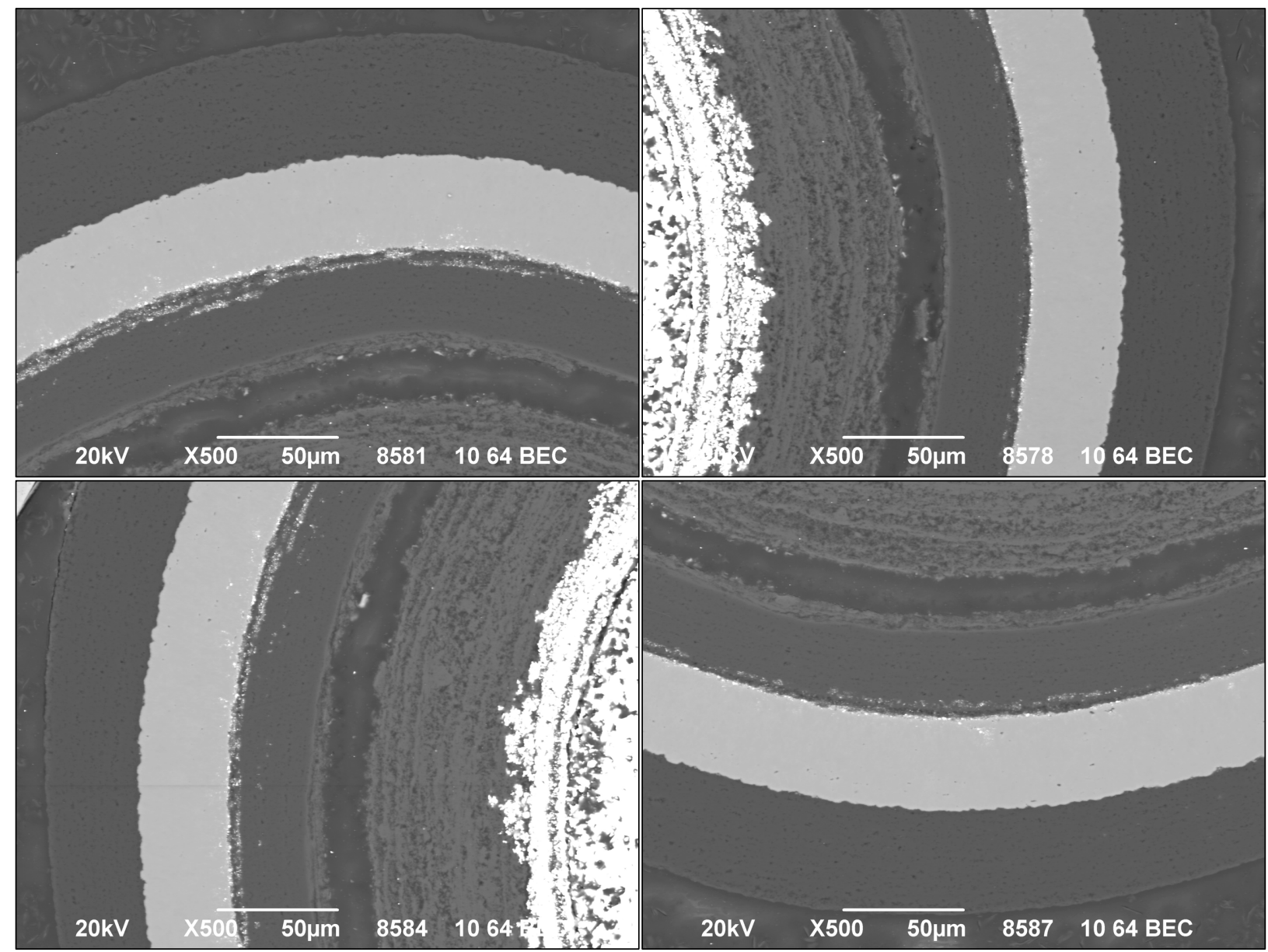

Figure 7-7. Four 500 $\times$ SEM magnification BEC images of Particle $643-\mathrm{RS} 15$ with ${ }^{110 \mathrm{~m}} \mathrm{Ag} \mathrm{M} / \mathrm{C}=1.29$.

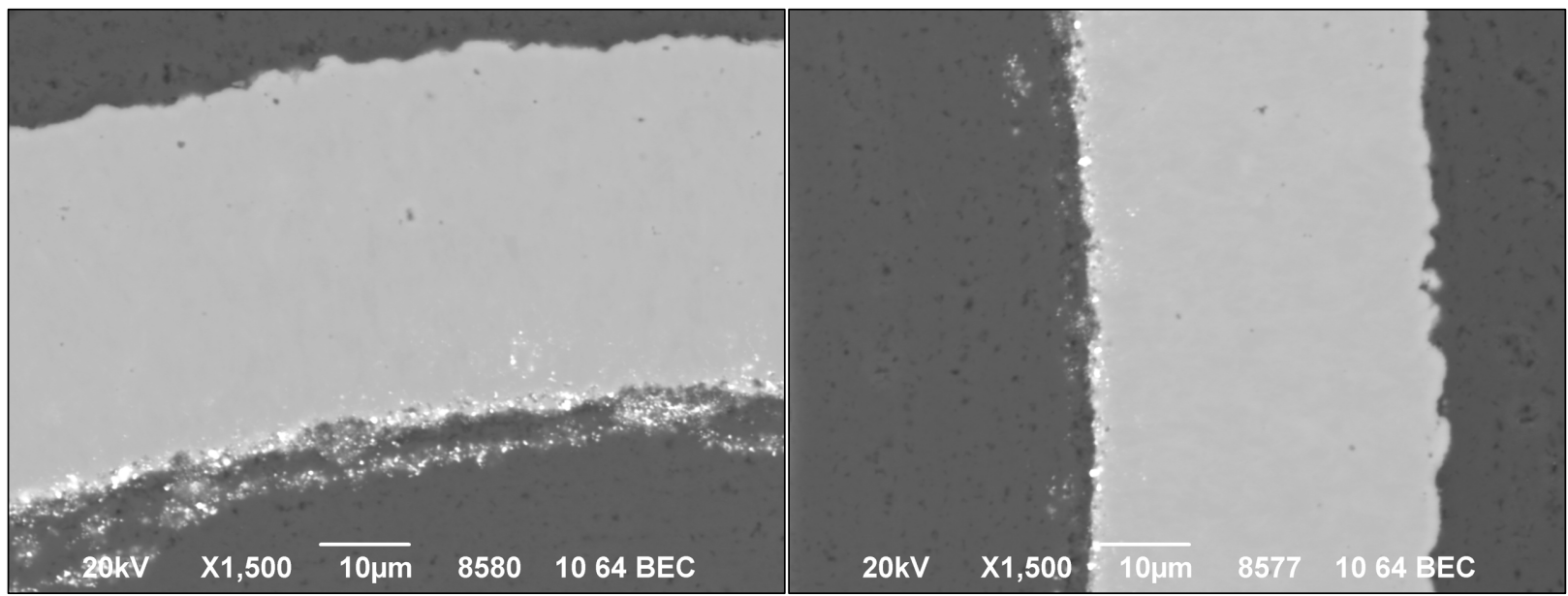

Figure 7-8. Two 1500 $\times$ SEM magnification BEC images of Particle $643-\mathrm{RS} 15$ with ${ }^{110 \mathrm{~m}} \mathrm{Ag} \mathrm{M} / \mathrm{C}=1.29$. 


\section{PARTICLE 643-RS27 OVERVIEW}

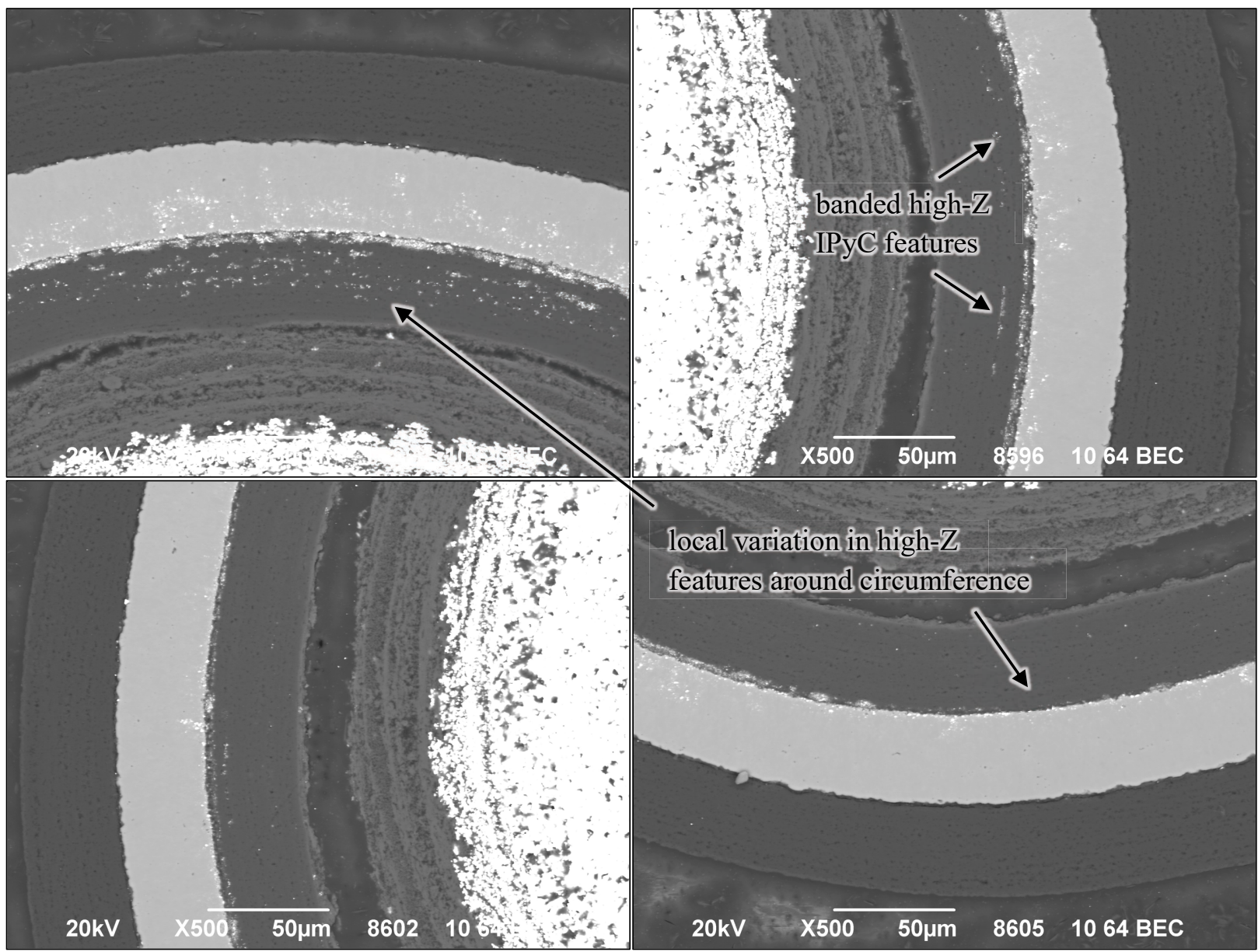

Figure 7-9. Four 500 $\times$ SEM magnification BEC images of Particle $643-R S 27$ with ${ }^{110 \mathrm{~m}} \mathrm{Ag} \mathrm{M} / \mathrm{C}<0.93$.

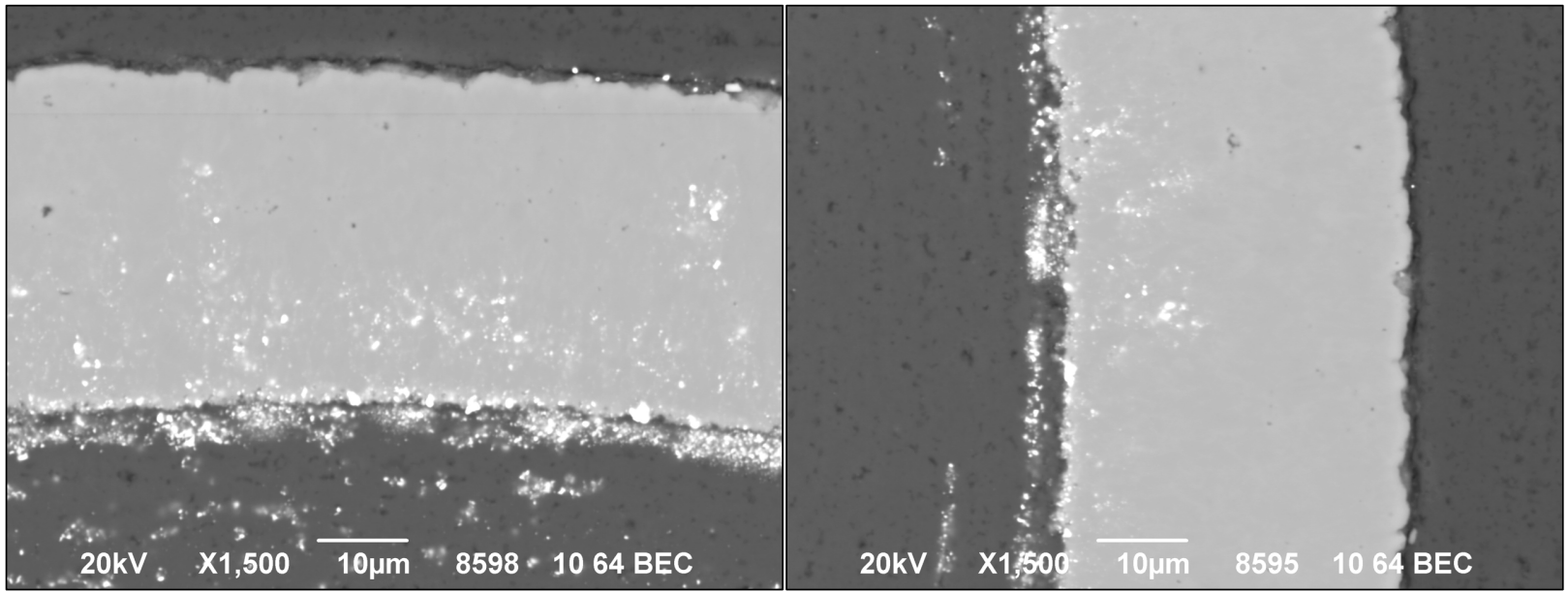

Figure 7-10. Two 1500 $\times$ SEM magnification BEC images of Particle 643-RS27 with ${ }^{110 \mathrm{~m}} \mathrm{Ag} \mathrm{M} / \mathrm{C}<0.93$. 
PARTICLE 643-RS43 OVERVIEW

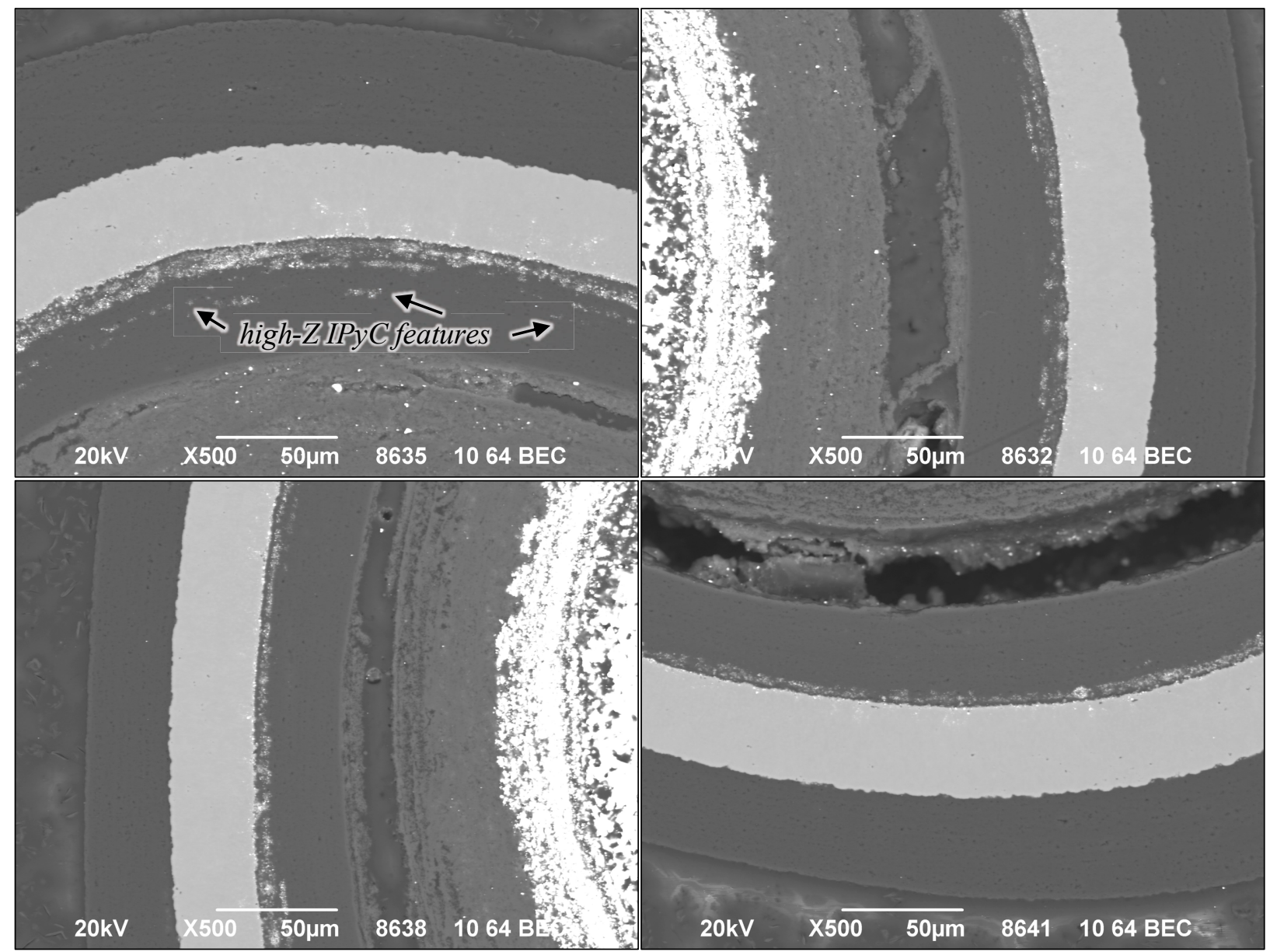

Figure 7-11. Four 500 $\times$ SEM magnification BEC images of Particle 643-RS43 with ${ }^{110 \mathrm{~m}} \mathrm{Ag} \mathrm{M} / \mathrm{C}<1.43$.

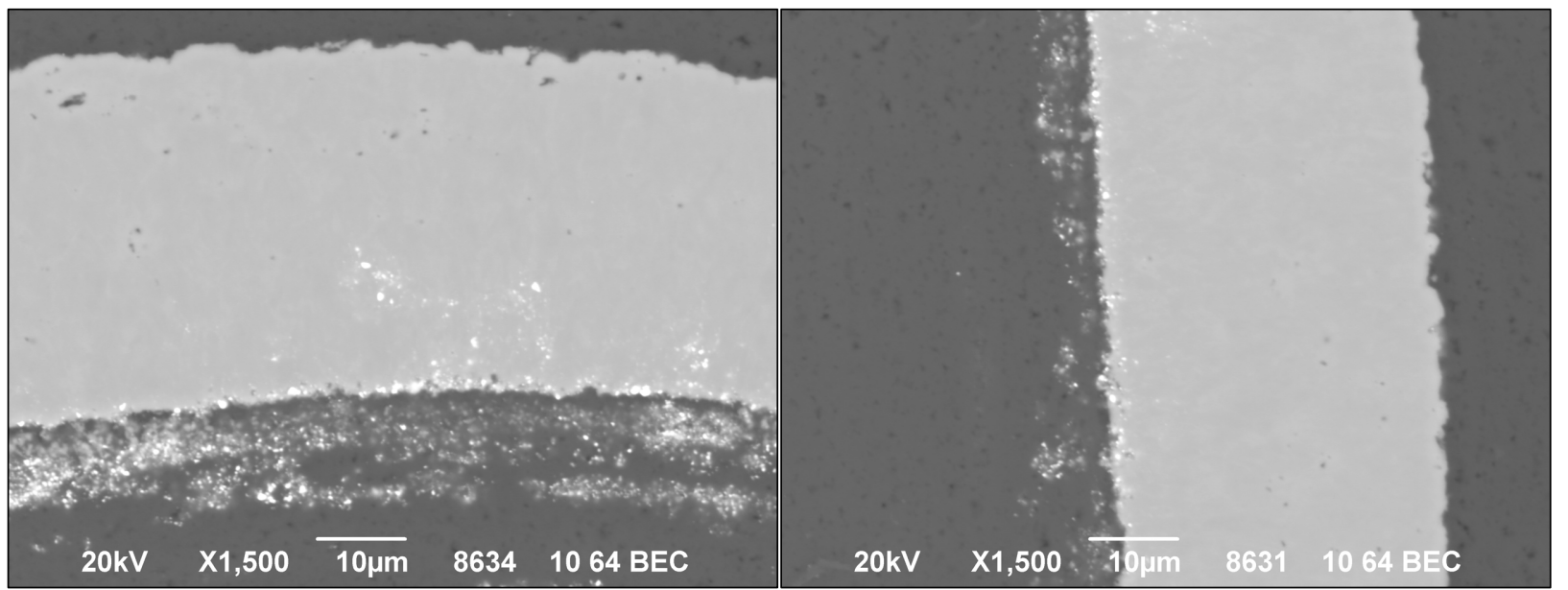

Figure 7-12. Two 1500 $\times$ SEM magnification BEC images of Particle 643-RS43 with ${ }^{110 \mathrm{~m}} \mathrm{Ag} \mathrm{M} / \mathrm{C}<1.43$. 


\section{PARTICLE 643-RS27 BEC/SEI PAIRS}

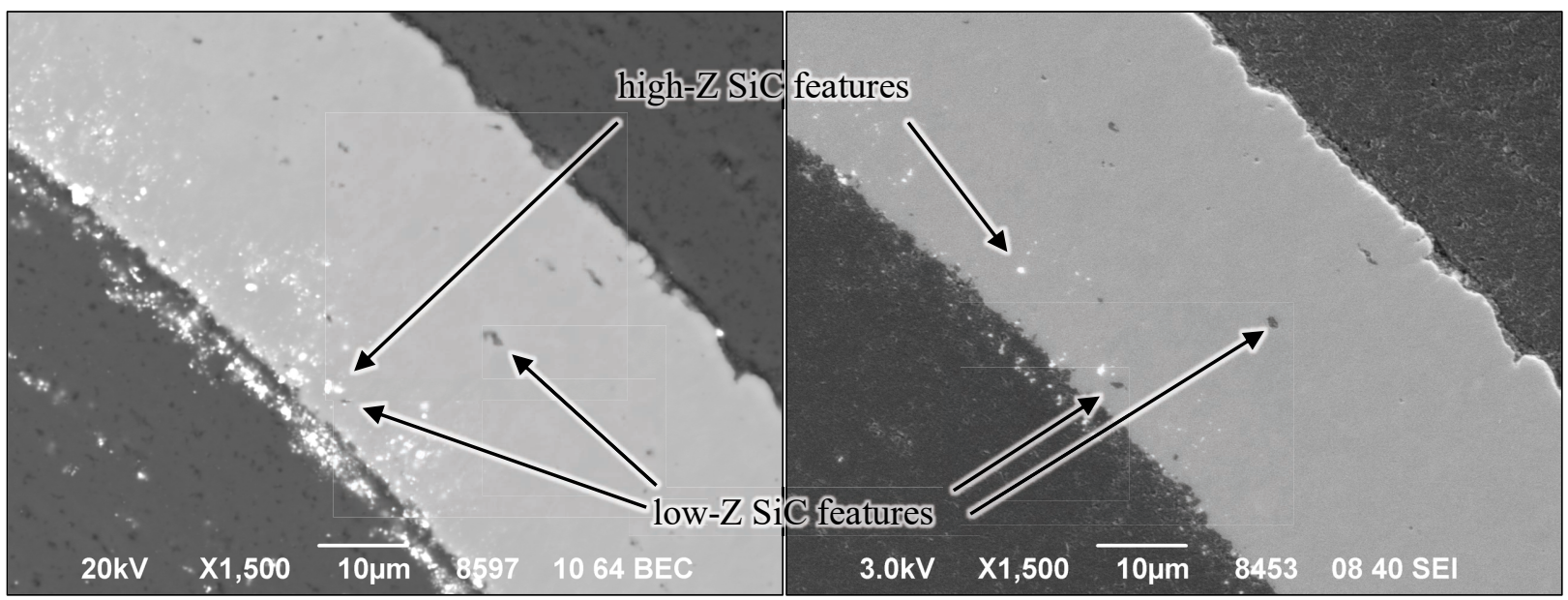

Figure 7-13. BEC and SEI micrographs of the same region of Particle 643-RS27.

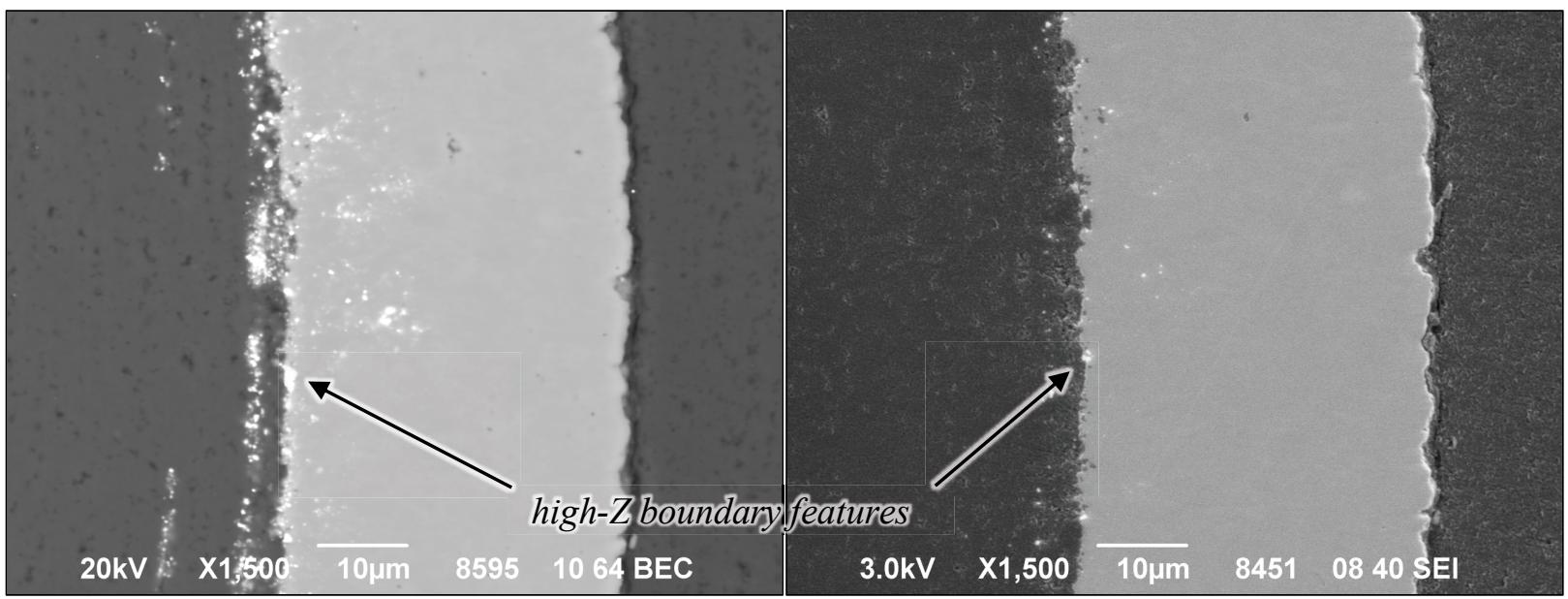

Figure 7-14. BEC and SEI micrographs of the same region of Particle 643-RS27.

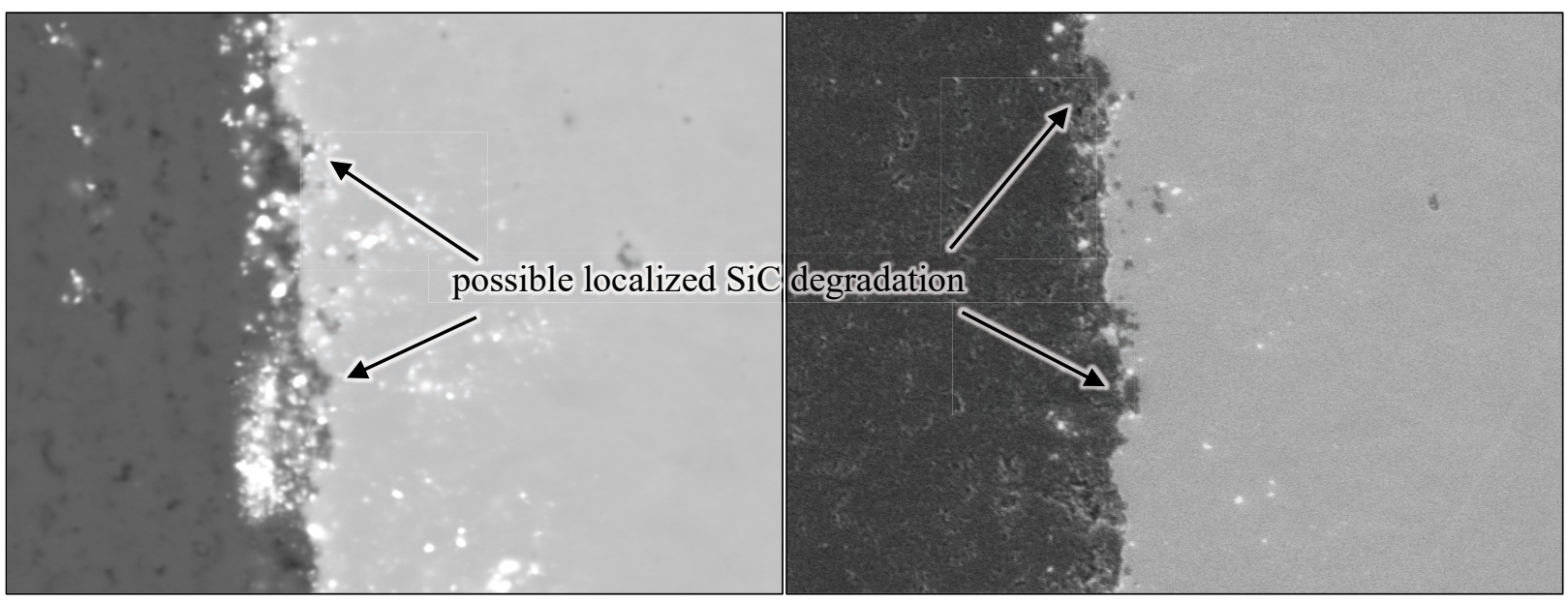

Figure 7-15. Magnified view of upper area of micrographs in Figure 7-14 showing apparent SiC degradation. 
Particle 643-RS15 ( $\left.{ }^{110 \mathrm{~m}} \mathrm{Ag} \mathrm{M} / \mathrm{C}=1.29\right)$ appeared to have a relatively lower degree of high-Z SiC features penetrating into the $\mathrm{SiC}$ layer, with penetration mostly confined to $10 \mu \mathrm{m}$ from the IPyC/SiC boundary (Figure 7-7 and Figure 7-8). This is consistent with general trends observed in particles from other compacts with high silver retention. The distribution of high-Z SiC features in Particle 643-RS43 (Figure 7-11 and Figure 7-12) was similar to that in Particle 643-RS15, with perhaps marginally greater penetration into the $\mathrm{SiC}$. In comparison, the other two particles analyzed in this study had more high-Z $\mathrm{SiC}$ features, and the features were observed further from the IPyC/SiC boundary, which is consistent with general trends observed in particles from other compacts with lower silver retention. In Particle 643-RS27, most high-Z SiC features were confined to the inner half of the SiC, but features in some sectors were observed in the outer half of the $\mathrm{SiC}$ layer (Figure 7-9 and Figure 7-10). Compared to Particle 643-RS27, the high-Z SiC features observed in Particle 643-RS12 appeared to be present in slightly lower concentration and with slightly lower maximum penetration depth but with similar circumferential variation in the penetration depth (Figure 7-5 and Figure 7-6).

No particle-to-particle variations were noted in the distribution of high-Z boundary features, high-Z interface features, or high-Z IPyC features. However, circumferential variation within each particle was observed, and notably higher feature concentrations were observed where the buffer was still partially attached to the IPyC. Examination of irradiated AGR particles whose buffer layer shrank and pulled away from the buffer/IPyC interface has often revealed one remaining area of attachment. For example, 43 particles from Compact 6-4-2 were examined by polishing to near midplane, and 33 of these particles had nonfractured buffer layers that were detached from the IPyC. Of these 33 particles, 16 had one remaining attachment point that was visible in the polish plane, and there may have been attachment points in the other 17 that were not visible (Hunn et al. 2018d, Figure 10). The tendency for one area of the buffer to remain attached may be because the local stresses that induce the shrinking buffer to tear away are lower after most of the buffer is detached. The upper left micrographs in Figure 7-9 and Figure 7-11, as well as the associated higher magnificant micrographs in Figure 7-10 and Figure 7-12, show sectors where the buffer was still partially attached in Particles 643-RS27 and RS-43, respectively. These sectors exhibited a higher abundance of high-Z IPyC features and a higher density of high-Z interface features as compared to other circumferential locations in the same particle cross section. These sectors also exhibited the maximum penetration of high-Z SiC features. Given that the high-Z features observed in the IPyC and $\mathrm{SiC}$ layers were clusters of fission products and actinides that migrated from the kernel, it is conceivable that locations with a shorter and more direct path from the kernel may have received a greater flux of fission products and actinides. It is evident from the observation of a large number of irradiated particles during AGR PIE that buffer separation from the IPyC is a dynamic process during irradiation. It is likely that buffer separation progresses along the buffer/IPyC interface after initial separation occurs in one or more localized regions, so the total time that the buffer remains attached during irradiation varies from one spherical sector to the next.

\subsection{ELEMENTAL ANALYSIS}

The composition of select features interacting with the TRISO layers was determined by EDS using Point-ID mode. Selected high-Z SiC features, high-Z boundary features, high-Z interface features, and high-Z IPyC features were analyzed for all particles. Features were further categorized into two compositional types based on their elemental content. Features with EDS spectra that indicated the predominant high-Z species was uranium were labeled as U-rich features. Identification as a $U$-rich feature was based on exhibiting an apparent concentration ratio of uranium to palladium or rhodium that was greater than 5:1. The $U$-rich features presented some compositional variation, with some features containing contributions from palladium, rhodium, molybdenum, and/or zirconium. Examples of several U-rich features are shown in Figure 7-16, and corresponding spectra are shown in Figure 7-17. The U-rich features were predominantly observed in the $\mathrm{SiC}$ layer and on the IPyC/SiC boundary. 


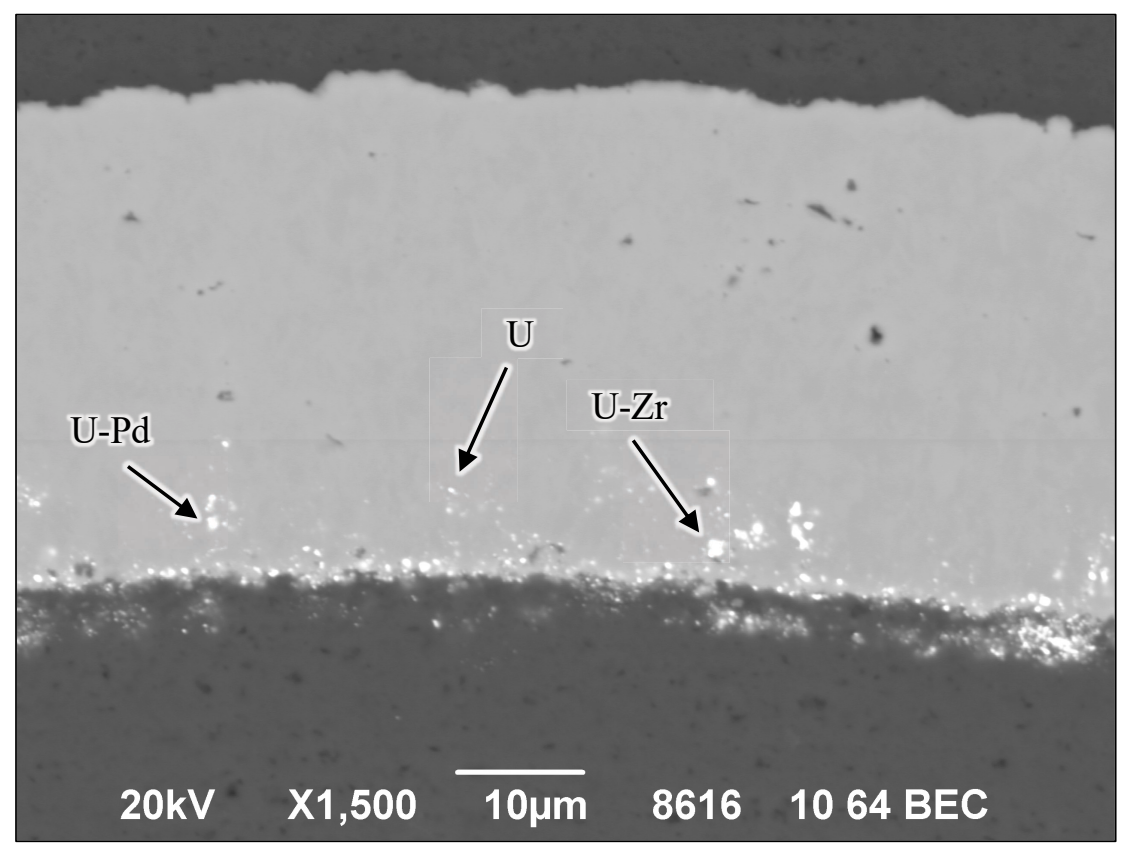

Figure 7-16. Examples of $U$-rich features embedded in the SiC layer of Particle 643-RS12.

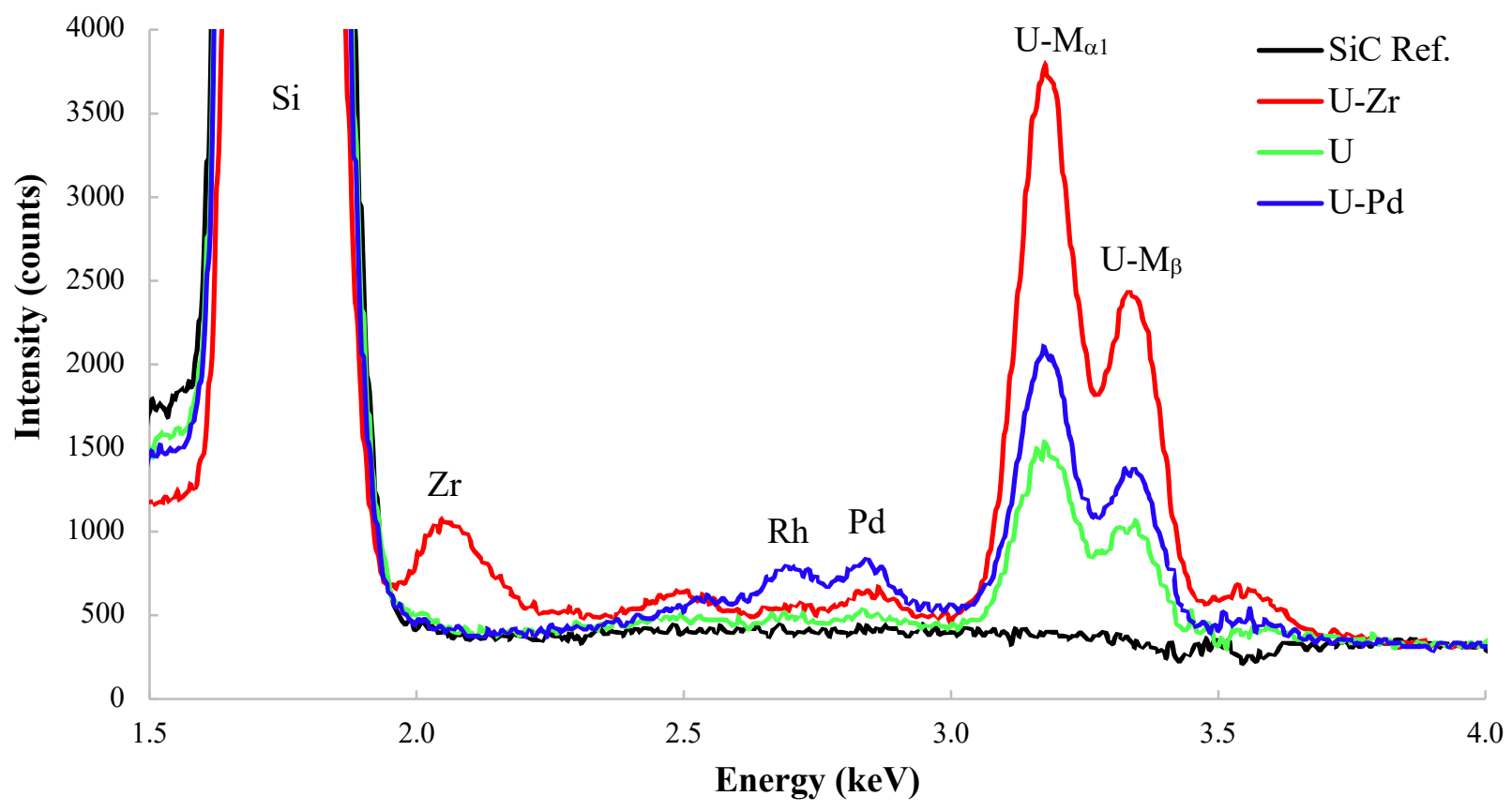

Figure 7-17. EDS spectra of Point-ID locations centered on $\boldsymbol{U}$-rich features labeled in Figure 7-16Error! Reference source not found..

Features that contained varying contributions from uranium, palladium, rhodium, and ruthenium were classified as complex features. Complex features displayed significant compositional variation, with some having a higher concentration of either palladium, rhodium, or uranium. The apparent concentration of the dominant component was not more than three times that of any other component. Ruthenium always appeared as a minor element when detected. Complex features were further categorized as $P d$-complex, $U$-complex, or Rh-complex features, depending on their dominant species. Examples of these three complex features embedded in the SiC layer are shown in Figure 7-18, and corresponding spectra are shown in Figure 7-19. 


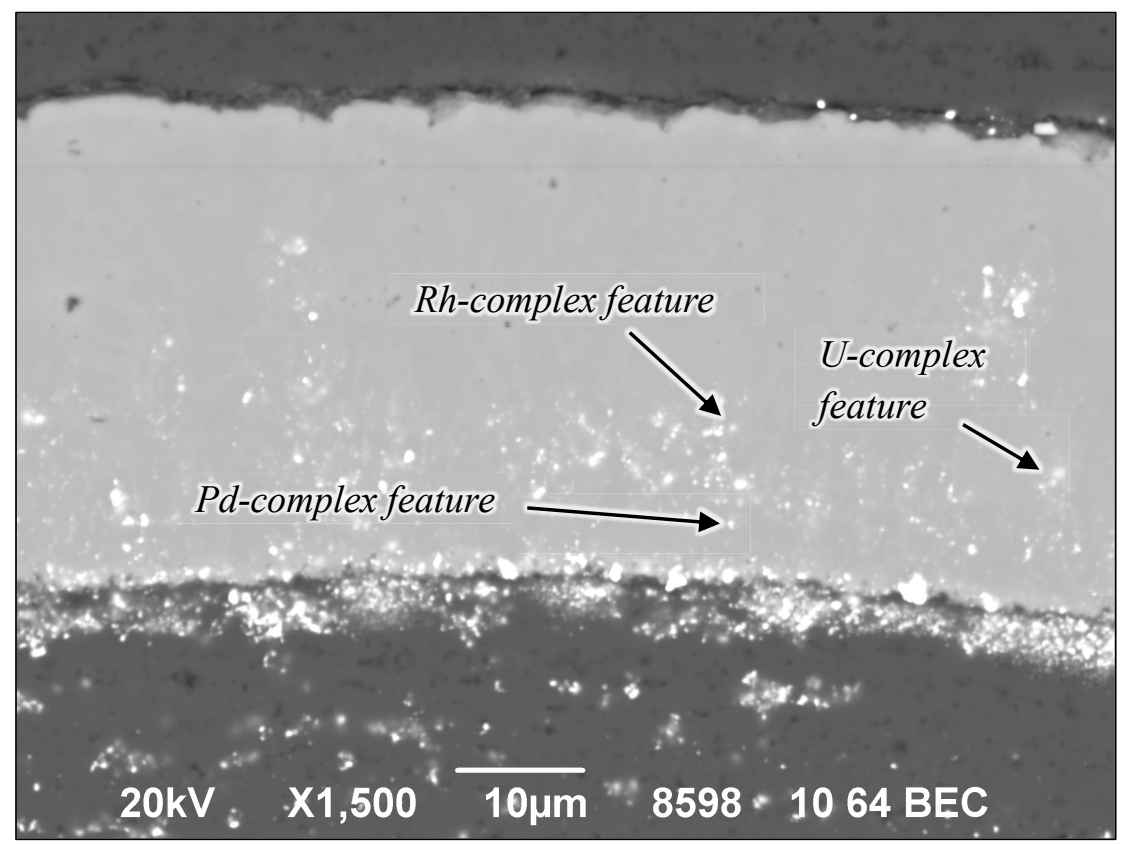

Figure 7-18. Examples of complex features embedded in the SiC layer of Particle 643-RS27.

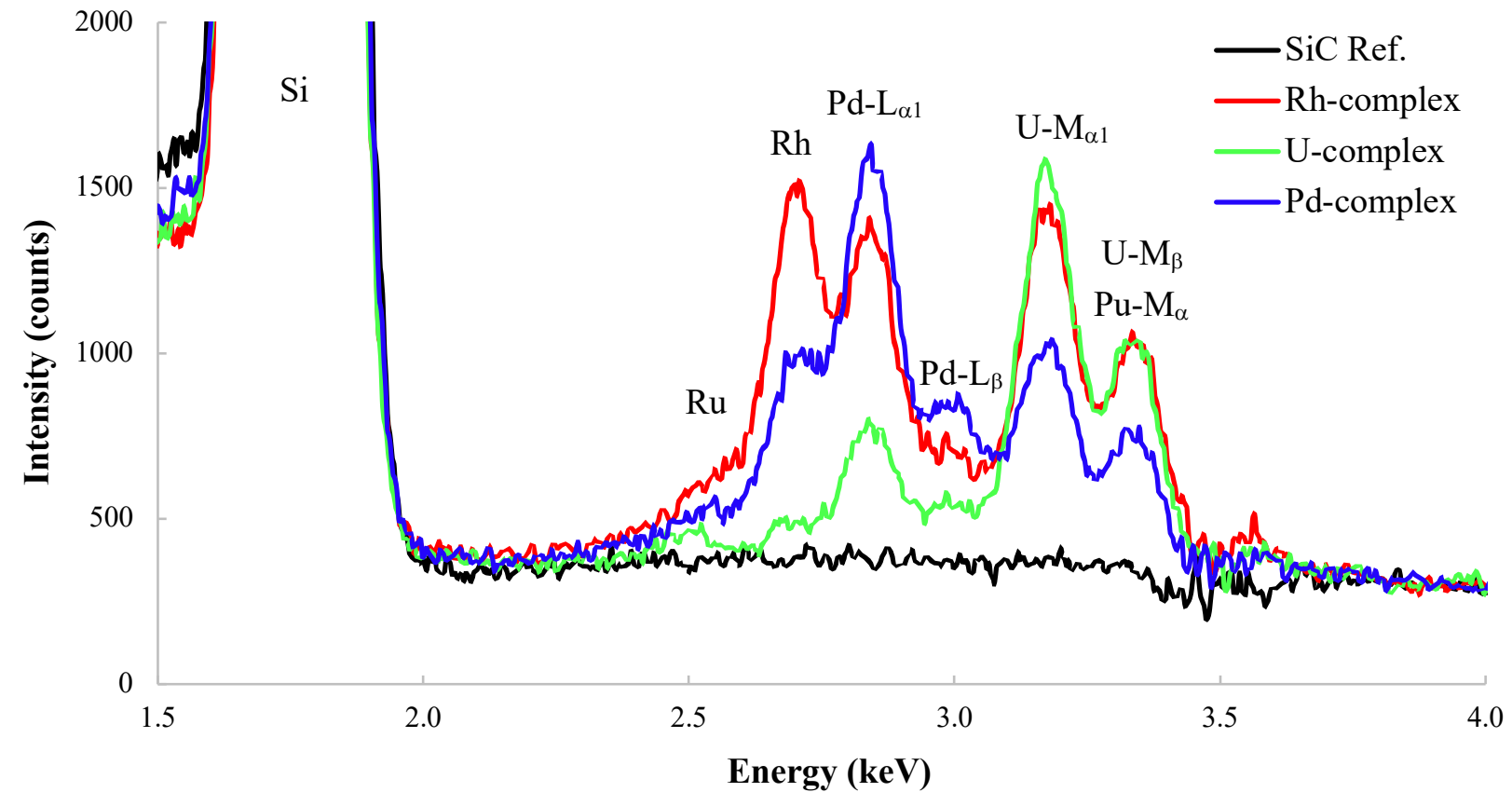

Figure 7-19. EDS spectra of Point-ID locations centered on complex features labeled in Figure 7-18.

The observed complex features were likely silicides, based on analysis of complex features located in the $\mathrm{IPyC} / \mathrm{SiC}$ interface region and in the IPyC layer further from the IPyC/SiC boundary. Challenges were associated with explicitly identifying the composition of complex features of interest, because the large electron beam interaction volume relative to the feature volume led to significant contributions from the surrounding material. For complex features in the $\mathrm{SiC}$ or in the $\mathrm{IPyC} / \mathrm{SiC}$ interface region, contributions from the surrounding $\mathrm{SiC}$ limited the ability to confirm the presence of silicon in the features. However, complex features observed further out in the IPyC layer had contributions from palladium, uranium, and rhodium that were similar to those in or near the $\mathrm{SiC}$, but no silicon contributions from the surrounding IPyC. A comparison of the EDS spectra from complex features at the locations in the IPyC labeled in Figure 7-20, along with an IPyC reference spectrum, is shown in Figure 7-21. These spectra highlight the 
contribution of silicon in the complex features where the silicon background was low. A comparison of features at different distances from the IPyC/SiC boundary showed that they maintained significant silicon intensity above that expected from detector artifacts or contributions from surrounding material. In particular, the features $>20 \mu \mathrm{m}$ away from the interface showed Si $\mathrm{K}_{\alpha}$ intensity ten times greater than the surrounding IPyC reference, confirming that these complex features contained silicon.

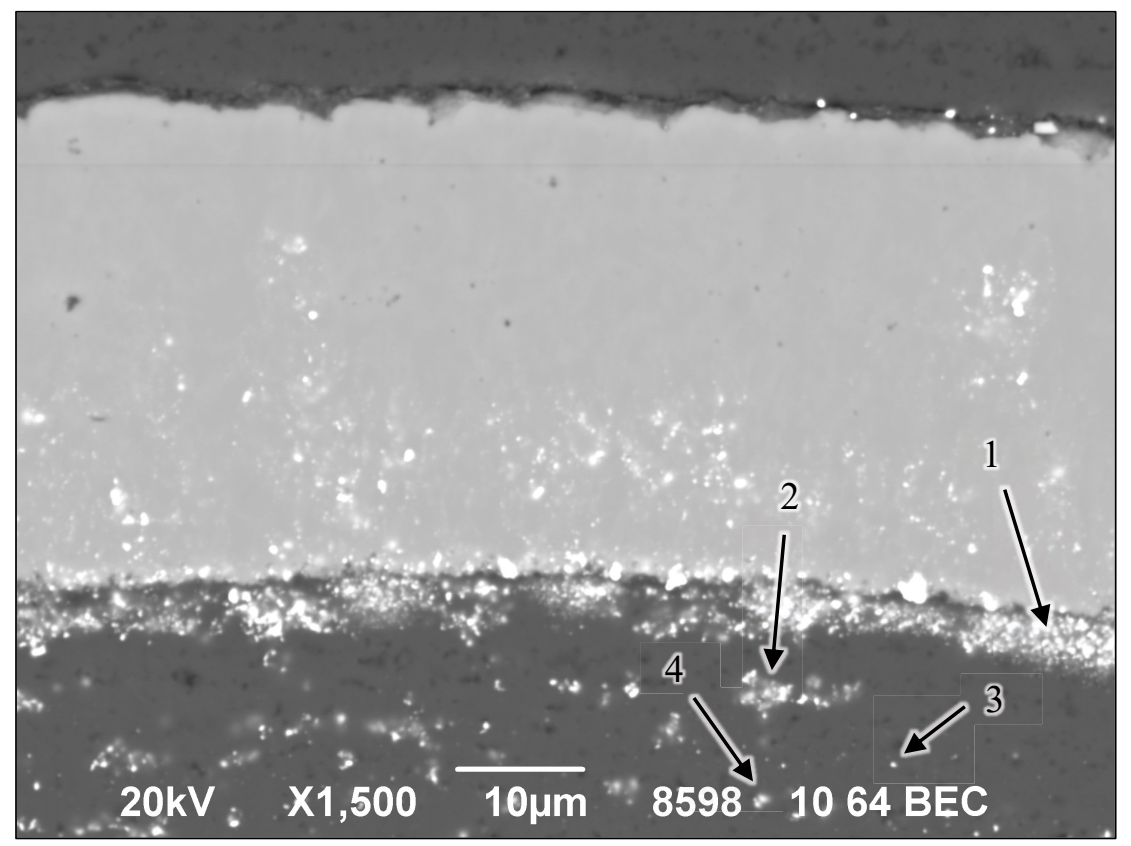

Figure 7-20. Composition of complex features at different locations in the IPyC of Particle 643-RS27.

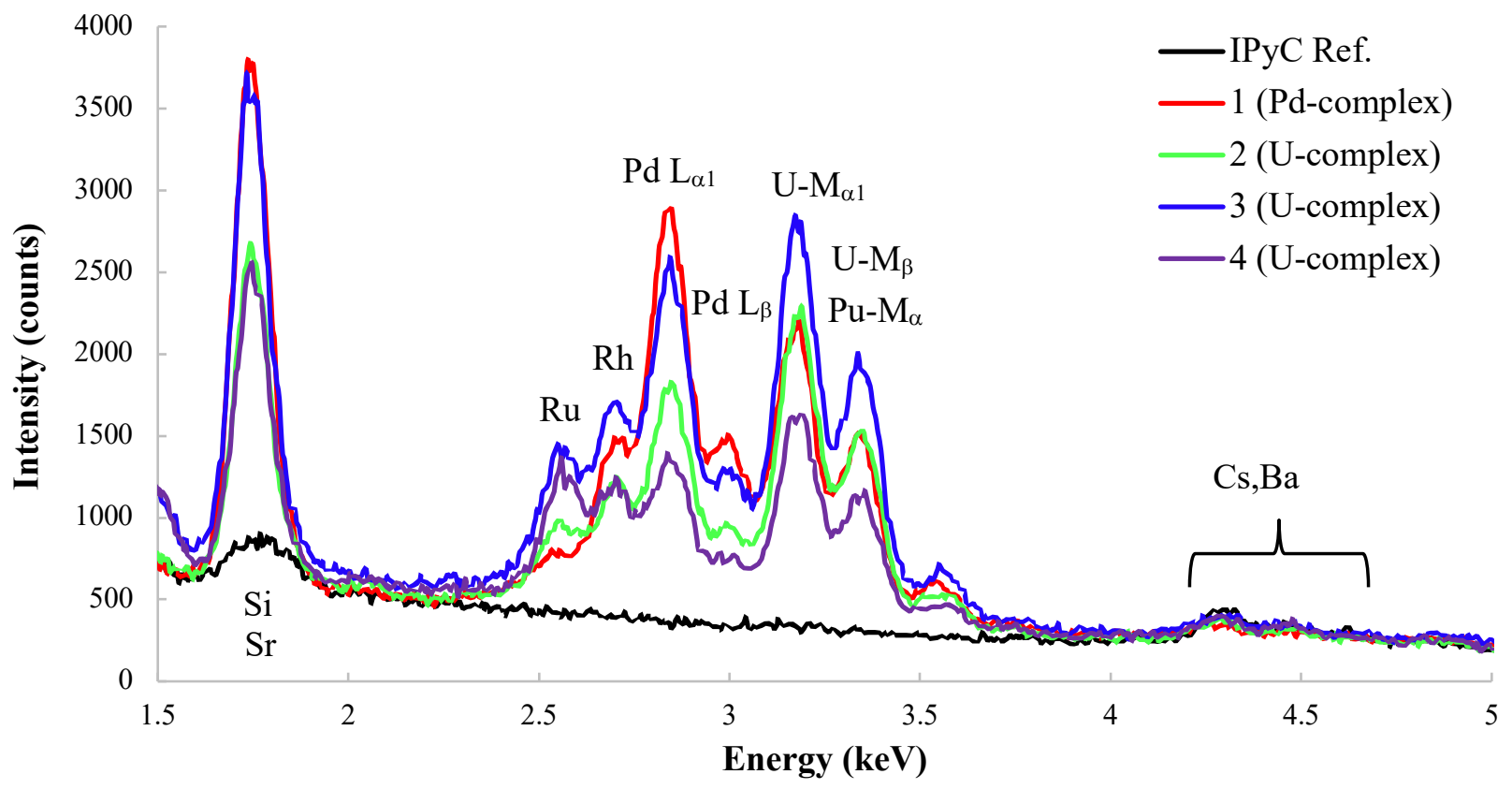

Figure 7-21. EDS spectra of Point-ID locations centered on complex features labeled in Figure 7-20.

Figure 7-21 shows that the complex features in the IPyC had more contributions from ruthenium than those shown in Figure 7-19, as well as minor contributions from barium, cesium, and strontium. The contributions from barium, cesium and strontium were present in all high-Z IPyC features, as well as the IPyC reference spectra. This suggests low concentrations of these fission product species throughout the entire IPyC volume. 
In many of the complex features, the presence of plutonium in addition to uranium was inferred from the relative intensity of the peak from $3.178 \mathrm{keV} \mathrm{U}-\mathrm{M}_{\alpha} \mathrm{X}$-rays compared to the intensity of a higher energy

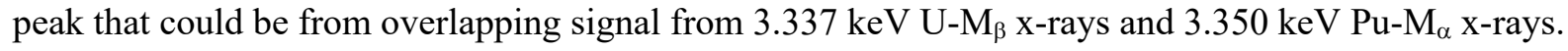
The presence of plutonium in a feature resulted in a higher ratio of the higher energy peak vs. the lower energy peak, compared to the ratio when only uranium was present. In Figure 7-19, the spectrum from the $R h$-complex feature indicates elevated plutonium relative to the spectrum from the $U$-complex feature. The possible presence of plutonium was primarily observed in the high-Z IPyC features.

The fraction of each compositional type observed for each location-based category is shown in Table 7-2 through Table 7-5 for the four specimens. The composition of the features at each location generally varied, with a predominance of $U$-rich and $U$-complex compositional types on the IPyC/SiC boundary relative to all other locations, while the high-Z interface features were exclusively $U$-complex or $P d$-complex compositional types. One possible difference in the data from Particles 643-RS15 and 643-RS27 compared to the data from Particles 643-RS12 and 643-RS43 was an increased fraction of $P d$-complex features in the SiC layer of Particles 643-RS15 and 643-RS27. Particle 643-RS15 was also unique in that all catalogued high-Z IPyC features were of the $P d$-complex compositional type.

Table 7-2. Relative population of each compositional type observed in high-Z SiC features

\begin{tabular}{lcccc}
\hline Type & 643-RS12 & 643-RS15 & 643-RS27 & 643-RS43 \\
\hline U-rich & 0.41 & 0.44 & 0.38 & 0.33 \\
Rh-complex & 0.07 & 0.00 & 0.13 & 0.25 \\
U-complex & 0.33 & 0.22 & 0.21 & 0.33 \\
Pd-complex & 0.19 & 0.33 & 0.29 & 0.08 \\
\hline
\end{tabular}

Table 7-3. Relative population of each compositional type observed in high-Z boundary features

\begin{tabular}{lcccc}
\hline Feature & 643-RS12 & 643-RS15 & 643-RS27 & 643-RS43 \\
\hline U-rich & 0.44 & 0.50 & 0.75 & 0.75 \\
Rh-complex & 0.00 & 0.17 & 0.00 & 0.13 \\
U-complex & 0.56 & 0.33 & 0.25 & 0.13 \\
Pd-complex & 0.00 & 0.00 & 0.00 & 0.00 \\
\hline
\end{tabular}

Table 7-4. Relative population of each compositional type observed in high-Z interface features

\begin{tabular}{lcccc}
\hline Feature & 643-RS12 & 643-RS15 & 643-RS27 & 643-RS43 \\
\hline U-rich & 0.00 & 0.00 & 0.00 & 0.00 \\
Rh-complex & 0.00 & 0.00 & 0.00 & 0.00 \\
U-complex & 0.27 & 0.20 & 0.00 & 0.60 \\
Pd-complex & 0.73 & 0.80 & 1.00 & 0.40 \\
\hline
\end{tabular}

Table 7-5. Relative population of each compositional type observed in high-Z IPyC features

\begin{tabular}{lcccc}
\hline Feature & 643-RS12 & 643-RS15 & 643-RS27 & 643-RS43 \\
\hline U-rich & 0.43 & 0.00 & 0.07 & 0.18 \\
Rh-complex & 0.00 & 0.00 & 0.00 & 0.00 \\
U-complex & 0.29 & 0.00 & 0.80 & 0.36 \\
Pd-complex & 0.29 & 1.00 & 0.13 & 0.45 \\
\hline
\end{tabular}




\section{CONCLUSION}

AGR-2 UCO Compact 6-4-3 was safety tested by heating in flowing helium to $1,800^{\circ} \mathrm{C}$ and holding at temperature for $\sim 300 \mathrm{~h}$. Low levels of cesium release $\left(0.05\right.$ particle-equivalents of $\left.{ }^{134} \mathrm{Cs}\right)$ during safety testing were consistent with a conclusion that there were no particles with failed SiC or failed TRISO. Release of ${ }^{110 \mathrm{~m}} \mathrm{Ag}$ from Compact $6-4-3$ while heating to $1,800^{\circ} \mathrm{C}$ was relatively low $(0.16 \%$ of the calculated compact inventory) compared to many safety tested compacts that have released several tenths to tens of percent of their calculated ${ }^{110 \mathrm{~m}} \mathrm{Ag}$ when heated to $1,600-1,800^{\circ} \mathrm{C}$. However, a significant increase in the ${ }^{110 \mathrm{~m}} \mathrm{Ag}$ release rate from Compact 6-4-3 was observed after about $50 \mathrm{~h}$ at $1,800^{\circ} \mathrm{C}$, with the total cumulative release reaching $2.6 \%$ by the end of the test. While early safety test release has been determined to come predominantly from silver sequestered in the $\mathrm{OPyC}$ and matrix at the end of irradiation, the observed latter release from Compact 6-4-3 is understood to be the result of diffusion through intact SiC.

Post-safety test destructive examination of Compact 6-4-3 included DLBL, IMGA, XCT, and materialography, including microstructural analysis by optical microscopy, SEM, and EDS. The measured amounts of fission products and actinides detected on the surfaces of the deconsolidated particles and in the matrix debris by analyzing the pre-burn leach solutions and the matrix burn-leach solutions were consistent with there being no exposed kernels from failed TRISO, as expected from the observed safety test releases. Post-burn particle analysis was compromised by exposed kernels that resulted from TRISO layer damage during IMGA survey, so this analysis could not confirm the safety test conclusion that there were no particles with failed $\mathrm{SiC}$.

Approximately 79\% of the Compact 6-4-3 particles were surveyed with IMGA. Typical IMGA survey sampling fractions are $97-99 \%$. The abnormally low survey fraction was from a combination of incomplete matrix deconsolidation and incipient mechanical failure of the IMGA translational stages. The particle handling issues resulted in a large number of dropped particles and several needle position excursions with the potential for particle damage. No particles with defective or failed SiC or TRISO were identified by the IMGA survey. Out of five particles with abnormal ${ }^{137} \mathrm{Cs}$ and/or ${ }^{144} \mathrm{Ce}$ inventories detected in the IMGA survey, one particle with an abnormally low inventory was presumed to have an undersized kernel because it had a normal ${ }^{137} \mathrm{Cs} /{ }^{144} \mathrm{Ce}$ ratio, and the other four particles were evidently broken by the IMGA needle.

The retained inventories in the bare kernel and buffer-coated kernels measured with IMGA provided some insight regarding where cesium and europium were sequestered in the irradiated particles after $1,800^{\circ} \mathrm{C}$ safety testing. Very little cesium $(\sim 5 \%)$ was retained in the bare kernel, while $60-80 \%$ was retained in the buffer-coated kernels. This suggests that most of the cesium was sequestered in the buffer and IPyC layers of these particles. The bare kernel ${ }^{154} \mathrm{Eu}$ inventory was $<50 \%$ compared to $74-84 \%$ in the buffer-coated kernels. This suggests that there was also similar migration of europium out of the kernel into the surrounding carbon layer. While these observations were based on a very limited sample size, they suggest that there would be value in performing a systematic study to discern where certain fission products and actinides reside in the TRISO particle after irradiation and after safety testing. TRISO fragments could be obtained by physically breaking particles to isolated kernels, partially coated kernels, and some layers. Fragments could be quickly inventoried by gamma counting or by other more intensive analyses.

Examinations of four particles with SEM imaging and EDS were completed to acquire a general overview of fission product and actinide distribution outside the kernel. In general, all particles displayed similar classes of features in the TRISO layers, but with different distributions and populations. The elevated detection limits due to seven half-lives of ${ }^{110 \mathrm{~m}} \mathrm{Ag}$ decay did not allow particles with low-silver retention to be confidently identified, and this made it infeasible to identify trends in the observed distributions based on silver retention. However, the one particle with measurable silver (Particle 643-RS15, M/C = 1.29) showed limited presence of high-Z SiC features, which is consistent with other analyses of AGR particles 
with high silver retention (Gerczak et al. 2016). Qualitatively, Particle 643-RS43 also had fission product and actinide distributions consistent with high silver retention, while Particles 643-RS12 and RS27 had distributions and populations more similar to that observed for particles with lower silver release.

Uranium was the predominant species in the majority of the high-Z SiC features and high-Z boundary features observed in AGR-2 Compact 6-4-3 after $1,800^{\circ} \mathrm{C}$ safety testing (Table 7-2 and Table 7-3); these features were categorized as $U$-rich features or $U$-complex features. This was different from what was observed in particles from as-irradiated AGR-2 compacts with similar irradiation temperatures (Gerczak et al. 2018). In the as-irradiated compacts, all the high-Z SiC features and high-Z boundary features included palladium as the predominant species; these were categorized as $P d$-only or $P d-U$ features. Presumably, palladium was originally the predominant species in the high-Z SiC features and high-Z boundary features in Compact 6-4-3 prior to safety testing. Based on the observed post-safety test feature composition in Compact 6-4-3, it is reasonable to conclude that palladium preferentially diffused out of the $\mathrm{SiC}$, changing the predominant species in the pre-existing high-Z SiC features and high-Z boundary features to uranium. It is also probable that new features were formed by diffusion of additional high- $Z$ species into the $\mathrm{SiC}$ layer. The apparent palladium depletion and addition of new high-Z SiC features and high-Z boundary features containing uranium as the predominant species has been observed during AGR-1 PIE and safety testing (Hunn et al. 2014b). In contrast to the relatively low concentration of palladium in the high-Z SiC features and high-Z boundary features in Compact 6-4-3 after safety testing, palladium was the predominant species in the high-Z interface features (Table 7-4). The elevated palladium concentration in these features may indicate that a more thermally-stable complex silicide formed in the interface region.

Relatively higher populations of high-Z SiC features and high-Z IPyC features were observed in Particles 643-RS27 and RS43 in sectors where the buffer was still partially attached to the IPyC. This suggests that the transport of fission products and actinides across the buffer/IPyC interface may play a prominent role in certain fission product and actinide distributions and concentrations outside the buffer. It is important to understand this further so it can be taken into account in analysis of observed inter- and intra-particle variation. 


\section{REFERENCES}

Baldwin, C. A., J. D. Hunn, R. N. Morris, F. C. Montgomery, C. M. Silva, and P. A. Demkowicz. 2012. "First Elevated Temperature Performance Testing of Coated Particle Fuel Compacts from the AGR-1 Irradiation Experiment." Paper HTR2012-3-027. Proc. 6th International Topical Meeting on High Temperature Reactor Technology (HTR-2012), Tokyo, Japan, October 28-November 1, 2012. Also published in Nucl. Eng. Des. 271: 131-141.

Barnes, C. M. and D. W. Marshall. 2009. FY 2009 Particle Fabrication and Coater Test Report. INL/EXT-09-16545, Revision 0. Idaho Falls, ID: Idaho National Laboratory.

Collin, B. P. 2014. AGR-2 Irradiation Test Final As-Run Report. INL/EXT-14-32277, Revision 2. Idaho Falls, ID: Idaho National Laboratory.

Demkowicz, P. A. 2013. AGR-2 Post Irradiation Examination Plan. PLN-4616, Revision 0. Idaho Falls, ID: Idaho National Laboratory.

Demkowicz, P. A., J. D. Hunn, R. N. Morris, I. J. van Rooyen, T. J. Gerczak, J. M. Harp, and S. A. Ploger. 2015. AGR-1 Post Irradiation Examination Final Report. INL/EXT-15-36407, Revision 0. Idaho Falls, ID: Idaho National Laboratory.

Demkowicz, P. A. and J. D. Stempien. 2019. AGR-2 Irradiation Experiment Fission Product Mass Balance. INL/EXT-19-53559, Revision 0. Idaho Falls, ID: Idaho National Laboratory.

Gerczak, T. J., J. D. Hunn, R. A. Lowden, and T. R. Allen. 2016. "SiC Layer Microstructure in AGR-1 and AGR-2 TRISO Fuel Particles and the Influence of Its Variation on the Effective Diffusion of Key Fission Products." J. Nucl. Mater. 480: 1-14.

Gerczak, T. J., J. D. Hunn, R. N. Morris, F. C. Montgomery, D. J. Skitt, C. A. Baldwin, J. A. Dyer, and B. D. Eckhart. 2018. "Analysis of Fission Product Distribution and Composition in the TRISO Layers of AGR-2 Fuel," Paper HTR2018-0048. Proc. 9th International Topical Meeting on High Temperature Reactor Technology (HTR-2018), Warsaw, Poland, October 8-10, 2018.

Harp, J. M., P. A. Demkowicz, P. L. Winston, and J. W. Sterbentz. 2014. “An Analysis of Nuclear Fuel Burnup in the AGR-1 TRISO Fuel Experiment Using Gamma Spectrometry, Mass Spectrometry, and Computational Simulation Techniques." Nucl. Eng. Des. 278: 395-405.

Harp, J. M., P. A. Demkowicz, and J. D. Stempien. 2016. "Fission Product Inventory and Burnup Evaluation of the AGR-2 Irradiation by Gamma Spectrometry", Paper HTR2016-18593. Proc. 8th International Topical Meeting on High Temperature Reactor Technology (HTR-2016), Las Vegas, Nevada, November 6-10, 2016. Also published in Nucl. Eng. Des. 329: 134-141.

Hawkes, G. L. 2014. AGR-2 Daily As-Run Thermal Analyses. INL/ECAR-2476, Revision 1. Idaho Falls, ID: Idaho National Laboratory.

Hunn, J. D. and R. A. Lowden. 2006. Data Compilation for AGR-1 Variant 3 Coated Particle Composite LEU01-49T. ORNL/TM-2006/022, Revision 0. Oak Ridge, TN: Oak Ridge National Laboratory.

Hunn, J. D. 2010. AGR-2 Fuel Compacts Information Summary: Prepared for the NRC MELCOR Project. ORNL/TM-2010/296, Revision 1. Oak Ridge, TN: Oak Ridge National Laboratory.

Hunn, J. D., F. C. Montgomery, and P. J. Pappano. 2010a. Data Compilation for AGR-2 UCO Variant Compact Lot LEU09-OP2-Z. ORNL/TM-2010/017, Revision 1. Oak Ridge, TN: Oak Ridge National Laboratory.

Hunn, J. D., F. C. Montgomery, and P. J. Pappano. 2010b. Data Compilation for AGR-2 $\mathrm{UO}_{2}$ Compact Lot LEU11-OP2-Z. ORNL/TM-2010/055, Revision 1. Oak Ridge, TN: Oak Ridge National Laboratory. 
Hunn, J. D., T. W. Savage, and C. M. Silva. 2010. AGR-2 Fuel Compact Pre-Irradiation Characterization Summary Report. ORNL/TM-2010/226, Revision 0. Oak Ridge, TN: Oak Ridge National Laboratory.

Hunn, J. D., T. W. Savage, and C. M. Silva. 2012. AGR-1 Fuel Compact Pre-Irradiation Characterization Summary Report. ORNL/TM-2012/295, Revision 0. Oak Ridge, TN: Oak Ridge National Laboratory.

Hunn, J. D., R. N. Morris, C. A. Baldwin, F. C. Montgomery, C. M. Silva, and T. J. Gerczak. 2013. AGR1 Irradiated Compact 4-4-2 PIE Report: Evaluation of As-Irradiated Fuel Performance with Leach Burn Leach, IMGA, Materialography, and X-ray Tomography. ORNL/TM-2013/236, Revision 0. Oak Ridge, TN: Oak Ridge National Laboratory.

Hunn, J. D., C. A. Baldwin, T. J. Gerczak, F. C. Montgomery, R. N. Morris, C. M. Silva, P. A. Demkowicz, J. M. Harp, S. A. Ploger, I. J. van Rooyen, and K. E. Wright. 2014. "Detection and Analysis of Particles with Failed SiC in AGR-1 Fuel Compacts." Paper HTR2014-31254. Proc. 7th International Topical Meeting on High Temperature Reactor Technology (HTR-2014), Weihai, China, October 27-31, 2014. Also published in Nucl. Eng. Des. 360: 36-46.

Hunn, J. D., R. N. Morris, C. A. Baldwin, F. C. Montgomery, and T. J. Gerczak. 2014b. PIE on SafetyTested AGR-1 Compacts 5-3-3, 5-1-3, and 3-2-3. ORNL/TM-2014/484, Revision 0. Oak Ridge, TN: Oak Ridge National Laboratory.

Hunn, J. D., R. N. Morris, C. A. Baldwin, and F. C. Montgomery. 2015. Safety-Testing of AGR-2 UO 2 Compacts 3-3-2 and 3-4-2. ORNL/TM-2015/388, Revision 0. Oak Ridge, TN: Oak Ridge National Laboratory.

Hunn, J. D., R. N. Morris, C. A. Baldwin, and F. C. Montgomery. 2016. Safety-Testing of AGR-2 UCO Compacts 5-2-2, 2-2-2, and 5-4-1. ORNL/TM-2016/423, Revision 1. Oak Ridge, TN: Oak Ridge National Laboratory.

Hunn, J. D., R. N. Morris, C. A. Baldwin, Z. M. Burns, F. C. Montgomery, and D. J. Skitt. 2017. SafetyTesting of AGR-2 UCO Compacts 6-4-2 and 2-3-1. ORNL/TM-2017/439, Revision 0. Oak Ridge, TN: Oak Ridge National Laboratory.

Hunn, J. D., R. N. Morris, F. C. Montgomery, T. J. Gerczak, D. J. Skitt, G. W. Helmreich, B. D. Eckhart, and Z. M. Burns. 2018a. Safety-Testing and Post-Safety-Test Examination of AGR-2 UCO Compact 2-3-2 and AGR-2 $U_{2}$ Compact 3-4-1. ORNL/TM-2018/956, Revision 0. Oak Ridge, TN: Oak Ridge National Laboratory.

Hunn, J. D., T. J. Gerczak, F. C. Montgomery, D. J. Skitt, C. A. Baldwin, G. W. Helmreich, B. D. Eckhart, and J. A. Dyer. 2018b. AGR-2 As-Irradiated UCO Compact 5-4-2 PIE Report. ORNL/TM2018/863, Revision 0. Oak Ridge, TN: Oak Ridge National Laboratory.

Hunn, J. D., R. N. Morris, F. C. Montgomery, T. J. Gerczak, D. J. Skitt, C. A. Baldwin, J. A. Dyer, G. W. Helmreich, B. D. Eckhart, Z. M. Burns, P. A. Demkowicz, and J. D. Stempien. 2018c. "PostIrradiation Examination and Safety Testing of US AGR-2 Irradiation Test Compacts." Paper HTR2018-0010. Proc. 9th International Topical Meeting on High Temperature Reactor Technology (HTR-2018), Warsaw, Poland, October 8-10, 2018.

Hunn, J. D., T. J. Gerczak, F. C. Montgomery, D. J. Skitt, C. A. Baldwin, G. W. Helmreich, B. D. Eckhart, and J. A. Dyer. 2018d. AGR-2 Safety-Tested UCO Compact 6-4-2 PIE Report. ORNL/TM2018/864, Revision 0. Oak Ridge, TN: Oak Ridge National Laboratory.

Hunn, J. D., T. J. Gerczak, R. N. Morris, F. C. Montgomery, D. J. Skitt, B. D. Eckhart, Z. M. Burns. 2019. Safety-Testing and Destructive Examination of AGR-2 UCO Compact 2-1-2. ORNL/TM2019/1201, Revision 0. Oak Ridge, TN: Oak Ridge National Laboratory.

Lowden, R. A. 2006. Fabrication of Baseline and Variant Particle Fuel for AGR-1. ORNL/CF-2006/02, Revision 0. Oak Ridge, TN: Oak Ridge National Laboratory. 
Morris, R. N., P. A. Demkowicz, J. D. Hunn, C. A. Baldwin, and E. L. Reber. 2014. "Performance of AGR-1 High Temperature Reactor Fuel During Post-Irradiation Heating Tests." Paper HTR201431135. Proc. 7th International Topical Meeting on High Temperature Reactor Technology (HTR2014), Weihai, China, October 27-31, 2014. Also published in Nucl. Eng. Des. 306: 24-35.

Phillips, J. A., C. M. Barnes, and J. D. Hunn. 2010. "Fabrication and Comparison of Fuels for Advanced Gas Reactor Irradiation Tests." Paper HTR2010-236. Proc. 5th International Topical Meeting on High Temperature Reactor Technology (HTR-2010), Prague, Czech Republic, October 18-20, 2010.

Sterbentz, J. W. 2014. JMOCUP As-Run Daily Depletion Calculation for the AGR-2 Experiment in the ATR B-12 Position. ECAR-2066, Revision 2. Idaho Falls, ID: Idaho National Laboratory.

van Rooyen, I. J., D. E. Janney, B. D. Miller, P. A. Demkowicz, and J. Riesterer. 2014. “Electron Microscopic Evaluation and Fission Product Identification of Irradiated TRISO Coated Particles from the AGR-1 Experiment, A Preliminary Review," Nucl. Eng. Des. 271: 114-122. 